\title{
STUDIES IN THE MIGRATION OF LEPIDOPTERA
}

By C. B. Williams, Sc.D., G. F. Cockвill, Ph.D., M. E. Gibbs, M.A.,

(Rothamsted Experimental Station.)

and

J. A. Downes, B.Sc., A.R.C.S.

(Department of Zoology, University of Glasgow.)

Read 5th November, 1941.

With Two Plates and Sixty Diagrams and Maps.

I. Introduction

II. Some early references to migration. (C.B.w)

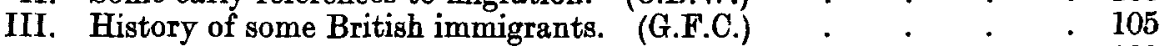

IV. Records at some British lightships. (M.E.G.) $\quad . \quad$. $\quad . \quad$. 129

V. Observations of Mr. and Mrs. Hodges in Florida. (C.B.W.) : $\quad 142$

VI. Special species. (C.B.W., except as marked) :-

(1) Danaus plexippus:-

Variation and geographical distribution . . . . 155

Migration and reproductive cycle in California. (J.A.D.) . 160

Migration in U.S.A., Central America and the W. Indies . 166

Migration in South America (D. erippus) . . . 173

Occurrence in Europe . $\quad . \quad$. $\quad . \quad$. $\quad .174$

(2) Phoebis eubule . . . . . . . . . . . . . 184

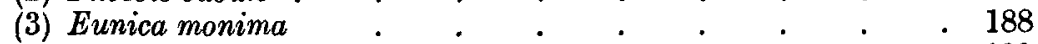

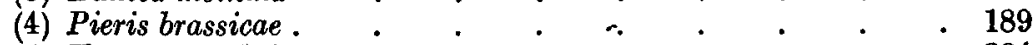

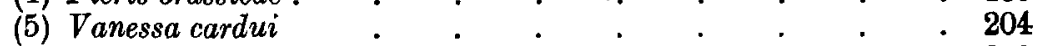

(6) Glycestha aurota $(=$ mesentina $):{ }^{\circ} \quad \cdot \quad \cdot \quad \cdot \quad \cdot \quad \cdot 209$

(7) Glycestha creona $(=$ severina) $\quad . \quad$. . . . . . . . 213

(8) Glycestha java . . . . . . . . . . . . . 214

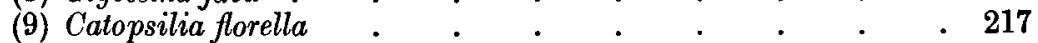

(10) Andronymus neander. . . . . . . . . . . . . 220

(11) Acratidae $\quad \cdot \quad \cdot \quad \cdot \quad \cdot \quad \cdot \quad \cdot \quad \cdot \quad \cdot \quad \cdot \quad \cdot \quad \cdot \quad \cdot 220$

VII. Experiments in marking butterflies. (G.F.C.) . . . . 222

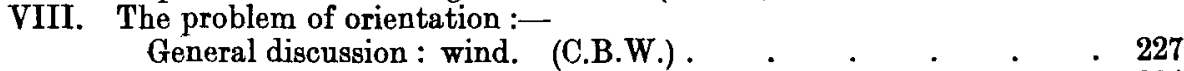

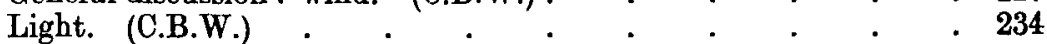

Magnetic field. (G.F.C.) : $: \quad . \quad . \quad . \quad . \quad . \quad 236$

IX. The problem of the return flight. (C.B.W.) :-
The evidence

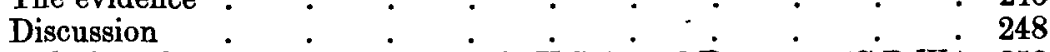

X. Correlation of occurrence of migrants in U.S.A. and Europe. (C.B.W.) 252

XI. Correlations of occurrence of British immigrants. (G.F.C.) • 254

XII. Suggested classification of density of flight. (C.B.W.) . $\quad . \quad 260$

XIII. Summary . . . . . . . . • . . 262

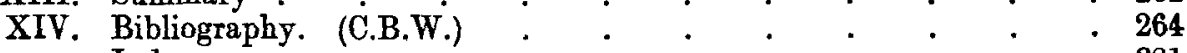

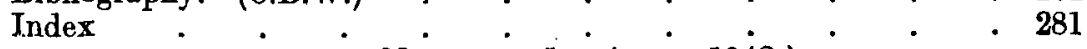

TRANS. R. ENT. SOC. LOND. 92. PART 1. (JULY 1942.) 


\section{InTRODUCTION.}

Is 1930 the senior author published (Williams 1930b) a survey of the evidence available on the subject of the migration of butterflies, and discussed many of the problems arising out of an analysis of this evidence.

In the intervening ten years considerable progress has been made and in particular the collection and study of records have been greatly facilitated by three events.

Firstly, in 1931 a group of amateurs was organised by Captain T. Dannreuther to observe the immigration of insects on the south coast of Britain. Under his enthusiastic leadership the organisation has spread to cover the greater part of the British Isles, with its nucleus in the "Insect Immigration Committee" of the South-Eastern Union of Scientific Societies. Through its action numerous records have been sent in not only from the land but also, with the co-operation of Trinity House, from the lightships and lighthouses off our coast.

Secondly, in 1937 the National Geographic Society of America published in their magazine a semi-popular article on Butterfly Migration (Williams 1937a). This magazine has a monthly circulation of over a million copies and, as a result of the publicity obtained, between two and three hundred correspondents sent in their observations. Some of these have continued to co-operate and have produced information of first-class importance.

Finally, in 1938 the Leverhulme Research Fellowship Trust made a grant for two years which enabled a full-time research entomologist and a clerk to be employed at Rothamsted.

On two occasions also the British Association for the Advancement of Science made small grants from which it was possible to purchase necessary filing material and other equipment; and the Royal Society has contributed $£ 100$ towards the cost of publication of this report.

The results presented are largely dependent on the help received from these organisations, and this opportunity is taken to thank them, and also Sir John Russell, Director of Rothamsted Experimental Station, for his encouragement of the work carried out there.

Mr. J. A. Downes wishes to express his thanks to Professors W. B. Herms and E. C. Van Dyke of the University of California for help during his investigations in that State.

G. F. Cockbill is author of the sections on the history of British migrants; the influence of the magnetic field; the results of marking insects, and the inter-correlations between the British migrants. These are part of a thesis accepted by the University of London for the Degree of Ph.D.

Miss M. E. Gibbs is author of the section on the records at the British light vessels.

J. A. Downes is author of the section on the migrations and reproductive cycle of $D$. plexippus in California, this being based on observations made during the tenure of a Commonwealth Fund Fellowship.

The rest of the report is by C. B. Williams.

The Bibliography (p. 264) contains all the references to the migration of Butterflies that we have been able to trace, and which are not in the Bibliography in Williams' book, including both older ones accidentally omitted from this and those published subsequently. Thus the bibliography in Williams' "Migration of Butterflies" (1930b) plus the Bibliography here is as complete a list as possible of the literature on the subject. 


\section{Some EARLY REFERENCES TO MIGRATION.}

By C. B. Wrlliams.

Some early references to the migration of butterflies have already been given (Williams $1930 \mathrm{~b}$, p. 12). Since then others have been traced which appear to be worth putting on record for their historical interest.

1100.

In F. Schnürrer's Chronik der Seuchen (History of Calamities) $1: 229$ (published in 1825) under the year 1100 A.D. there is the passage: "In Germany there were seen passing from the direction of Saxony to Bavaria swarms of insects, which from the resemblance of their outspread wings to tents, were called "Papilloren '." Schnürrer does not give the source of his information.

The word "Papilio" was used in Latin both for " tents" and for "butterflies." It seems possible that the insects were Cabbage White butterflies.

1508.

One of the most remarkable early records of a flight of butterflies that has so far been traced is that in Richard Turpyn's " The Chronicles of Calais in the Reigns of Henry VII and Henry VIII to the Year Fifteen Forty." The manuscript is in the British Museum and extracts from it were printed by the Camden Society, Vol. 35 (1846). On p. 7 of this volume appears " [1508] the twenty third of Henry the Seventh the ninth of July, beinge relyke Sonday, there was sene at Calleys [Calais] an innumerable swarme of whit buttarflyes cominge so thicke as flakes of snowe, that men being a shutynge in Saint Petar's felde without the towne of Calleys cowld not se the towne at fowre of the cloke in the aftarnone, they flewe so highe and so thicke."

I am indebted to Mrs. C. Lenanton for this interesting reference, which undoubtedly refers to a migration of Pieris brassicae or $P$. rapae.

In view of the fact that the correction of the calendar had not then been made the date would really be equivalent to about the 19th July in our present reckoning, which fits in well with the migrations that occur today (see p. 189).

1553.

John Sleidan (Sleidanius) in his "General History of the Reformation of the Church" (first published 1555), English edition 1689, book 25, p. 586, writes as follows about the funeral of Maurice, Duke of Saxony, who died on 11th July, 1553, "When the body of Maurice was carried through Leypsick to be buried, Joaachimus Carerarius made a funeral oration in commendation of him, enumerating also the prodigies which preceded his death, observing that drops of blood were found upon the leaves of some trees ... and in truth as to what concerns the drops of blood, they were observed in many places (and amongst the rest at Strasburg) to be found frequently in the beginning of July fallen upon herbs, the leaves of trees, stones and tiles of houses. Then there was a vast flight of butterflies, and there were some that were of opinion that these drops of blood proceeded from them; but the others thought they were presages of something that was to happen." The drops of blood appear to indicate a local emergence of large numbers of insects from the chrysalis. The "large flights" might possibly have been migrations, and again the date corresponds with the time of migration of the Cabbage Whites in Germany (see p. 189). 
1752.

According to Esper (1777, p. 136) Linnaeus is said to have recorded that Vanessa cardui was very abundant at Upsala in Sweden in 1752 . No reference is given and I have not been able to trace the original. Linnaeus refers briefly to the abundance in Fauna Suecica (2):33, but this is later than Esper's reference.

1803.

Haworth in his Lepidoptera Britannica (1803) p. 28, commenting on the appearance in England of Vanessa antiopa, writes : "There is something very extraordinary in the periodical but irregular appearance of this species, Papilio edusa (Colias hyale of this work) and Pap. cardui. They are plentiful all over the kingdom in some years, after which antiopa in particular will not be seen by anyone for eight, ten or more years, and then appears as plentifully as before. To suppose they come from the Continent is an idle conjecture, because the English specimens [of antiopa] are easily distinguished from all others by the superior whiteness of their borders. Perhaps the eggs in this climate, like the seeds of some vegetable, may occasionally lie dormant for several years and not hatch until some extraordinary but undiscovered coincidence awakes them into active life."

1827.

One of the earliest of records of butterfy migration in the tropics is by L. Guilding (1827), who writes: "A species of Colias was lately sent to me from Trinidad, which was observed in a continued flight of thousands traversing that island from west to east. They were also observed at sea in the neighbouring Gulf."

The species was undoubtedly a Catopsitia (Phoebis) and probably $P$. statira, which I observed myself in large numbers migrating across Trinidad from east to west ninety years later, in September and October 1918 (1919, Williams, Trans. ent. Soc. Lond. $1919: 76)$.

It may be interesting to add to these records the following extract from a Creole song from the West Indies, sent to me by Mrs. B. C. Scott. It was told to her in the island of Haiti by a Jamaican negro cook and relates to migrating yellow butterflies known as "Papillon St. Jean."

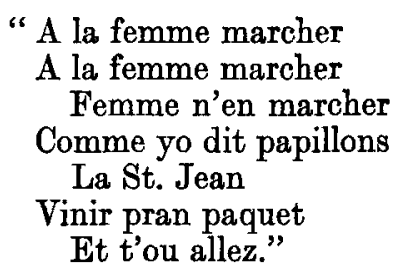

Mrs. Scott sends as a rough translation :-

"Like the marching peasant women,

Yes, the lines of walking women,

The women who keep on walking,

Like the Butterflies called

St. John;

Come, take up your bundles,

[and keep moving]

to wherever you are going." 


\title{
III. History of British mmigrants.
}

\author{
By G. F. Cockbill.
}

In his monograph on The Migration of Butterfies, Williams (1930b) pointed out the value of a historical survey of the British migrant Lepidoptera, and also emphasised that in Britain there was a unique opportunity for such a study because of the wealth of entomological and natural history journals in which were recorded the observations of collectors dating back a hundred years or more.

In 1937, Grant made a historical study of the Hawk moth C. lineata Fab. This work showed such possibilities that it was decided to extend the survey to include all the major British immigrants.

\section{Sources of information.}

The information was collected from entomological periodicals, general periodicals and Proceedings and Transactions of Natural History Societies. About eight hundred volumes were consulted and about fifty thousand records have been extracted, relating to forty species considered to be regular immigrants to Britain.

It is not practical to include in this paper all the references to the data because of their bulk, but they are available for consultation at the Entomological Department at Rothamsted Experimental Station.

\section{Sources of error.}

1. In collecting information from old journals there is always the possibility that some evidence has been overlooked, but the survey has included all the major British entomological periodicals since 1824, so that this error is believed to be at a minimum.

2. There is not much likelihood of errors in the data due to misidentification of species, since, apart from the fact that the British migrant Lepidoptera are fairly distinctive species, the field Lepidopterists, who are mainly responsible for the data, have always taken a pride in their ability to identify species correctly, and the rivalry that arose maintained a high standard of efficiency. Furthermore some magazines demanded inspection of a rare capture for verification.

3. There is a source of error arising from the fact that certain insects have at times enjoyed almost a fashionable interest among Lepidopterists during the past century, and consequently received increased attention in the literature until the interest waned. However, the rare migrant species have always been of sufficient interest to have been fully recorded whenever they occurred.

4. It is to be expected that rare occurrences tend to be recorded more fully than commonplace events. Thus rare insects, and conspicuous abundances or absences of common species, will be recorded; while normal abundances of the commoner species may receive less attention in the literature. To take an extreme case, it is likely that almost every capture or observation of $D$. plexippus in Britain has been recorded. On the other hand, $P$. brassicae is mentioned only when it becomes a particular pest, or when crops are singularly free from it; when there is no mention of $P$. brassicae in the literature it means that there is a normal abundance of the insect, and not that it is absent.

5. The number of entomologists has increased as time has passed, and a corresponding increase in the number of observations might be expected. It must be borne in mind, however, that while the number of entomologists has 
increased, their interests have become more diverse, and that whereas formerly Entomology was almost synonymous with the collection of Lepidoptera, it has now a far wider significance. The result is that the number of Lepidopterists contributing records to the literature of migrant insects does not appear to have been greatly affected until quite recently.

A special instance of this type of error is shown in the increased interest in migration of Lepidoptera since 1931, due to the activities of the Insect Immigration Committee of the South-Eastern Union of Scientific Societies. In this case, so numerous have the records of migrant Lepidoptera become that they must be considered separately from the previous records, so as not to throw the survey out of balance.

In spite of these apparently formidable errors, it is considered that there is still left a basis for a comparative analysis of species' abundances, and that the large bulk of data available in the past literature, if used discriminately, will yield valuable information. It must be emphasised that the numbers of insects obtained by this method are samples of the population, and give little, if any information of the absolute numbers of immigrants.

\section{Method of grading abundances.}

The recorded numbers of each species have been summed up as monthly and yearly totals. 'In order to compare the abundances of species readily, the annual totals for each species have been divided into six geometrically related grades. The grade of least abundance being Grade 1, and that of greatest abundance being Grade 6. In this way, abundances of rare and of regular migrants can be compared with due consideration for their particular degree of commonness.

Roughly speaking, the grades correspond to the following common verbal descriptions.

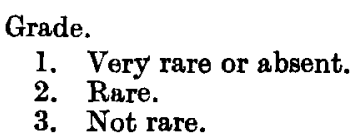

Grade.

4. Common.

5. Very common.

6. Quite unusually abundant.

Each description is of course taken as applying to the particular insect concerned. Thus only $25 \mathrm{~V}$. cardui recorded in a year would be "rare" but the same number of $D$. plexippus would be "quite unusually abundant."

The highest annual total recorded for each species has been amplified by fitting a sliding scale, which gives a $10 \%$ amplification at a maximum of 10 insects and a $50 \%$ increase at a maximum of 10,000 insects in one year. This device allows the highest recorded annual total to fall near the mean of Grade 6. Without amplification this would represent the extreme limit of the grade. The system also provides for the inclusion of higher totals than have yet been recorded, without upsetting the grading.

In addition, the amplification at higher levels tends to counteract the error of under-estimation of observers when large numbers of insects are seen; and at lower levels to compensate for the fact that when there is only a small immigration, the records tend to be limited by the numbers of insects, but when large immigrations occur, they tend to be limited by the number of observers.

In the first instance, when there is a very small immigration an increase in observers would probably have little effect on the number of insects recorded, but in the second case, when great numbers of insects are about, an increase 
in the numbers of observers would greatly affect the numbers of insects recorded.

In the case of the regular immigrants, the grades are arrived at by dividing the logarithm of the amplified total of the year of greatest abundance into six equal divisions. The corresponding antilogs. are obtained, and the yearly totals are provided with an index number, according to the grade in which each falls.

In the case of the rare migrants, Grade 1 is taken to be an absence of insects, and the range from 1 insect to the amplified maximum total is divided into five geometrically related grades. In taking Grade 1 as 0 insects, the assumption is made that an absence of records meant an absence of insects, and is to be regarded as being of the same category as an extreme rarity of the regular migrants, among which Grade 1 may include a very small number of insects, never more than 4, however, even in the most abundant species.

This method of arranging the annual totals into grades in geometrical proportion also makes it necessary that errors accompanying any year's total would have to be large to cause it to be placed in the wrong grade.

To take two examples (Table 1), $C$. croceus is representative of a common migrant and $A$. lathonia of a rare migrant.

The maximum annual total of records of $C$. croceus was 8778 in 1892 . This

\section{TABLE 1.}

Method of grading a common and a rare immigrant for annual abundance.

\begin{tabular}{|c|c|c|c|c|c|c|c|c|}
\hline \multirow{2}{*}{ Species } & \multirow{2}{*}{$\begin{array}{c}\text { Maxi- } \\
\text { mum } \\
\text { Annual } \\
\text { Total }\end{array}$} & \multirow{2}{*}{$\begin{array}{c}\text { Ampli- } \\
\text { fied } \\
\text { Total }\end{array}$} & \multicolumn{6}{|c|}{ Grades } \\
\hline & & & 1 & 2 & 3 & 4 & 5 & 6 \\
\hline $\begin{array}{l}\text { C. croceus } \\
\text { A. lathonia }\end{array}$ & $\begin{array}{c}8,778 \\
50\end{array}$ & $\begin{array}{r}13,180 \\
67\end{array}$ & $\begin{array}{c}0-4 \\
0\end{array}$ & $\begin{array}{c}5-23 \\
1-2\end{array}$ & $\begin{array}{c}24-114 \\
3-5\end{array}$ & $\begin{array}{c}115-558 \\
6-12\end{array}$ & $\begin{array}{c}559-2,710 \\
13-29\end{array}$ & $\begin{array}{c}2,711-13,180 \\
30-67\end{array}$ \\
\hline
\end{tabular}

figure, when amplified, became 13,180, which gave six logarithmic grades as shown. Grade 1 included $0-4$ insects. The highest annual total of $A$. lathonia was 50 in 1872; when amplified this total became 67 . The grades are shown in Table 1 with Grade 1 being 0 insects.

The maximum annual totals and grade range of all species are shown in Table 2. The totals are the highest for the period 1824 to 1939 except in the cases of $P$. napi, $V$. cardui, $V$. atalanta and $P$. gamma, where they are the highest for the period 1824 to 1931 .

In Table 3 the total monthly records for each species from 1824 to 1939 and the grand totals are shown. The grand totals of $P$. rapae and $P$. gamma are given for the period 1824 to 1931 only. The totals for the months where peaks of abundance occur are shown in heavy type. It will be seen that in some cases there are two peaks, one in spring and the other in late summer.

Table 4 (A-D) shows the annual totals of all species for the period 1824 to 1931. Absences of records are shown by dashes. The species are arranged in families.

Figs. 1, 2, 3 and 4 show the grade indices of the Butterflies, Hawk-moths, Noctuids and miscellaneous species respectively in the form of histograms. A dotted vertical line indicates the year when the records for each species began. The years 1857 and 1931, between which most of the correlations were 
calculated (see p. 254), are marked by a dotted vertical line passing through all species. In all these figures the base line represents Grade 1.

Constant reference will be made later to the above diagrams and tables.

History of the Species.

Danaus plexippus (fig. 1).

This immigrant from America is fully dealt with on p. 174 and will not be commented upon here.

\section{Nymphalis antiopa (fig. 1).}

In 1828, two were taken. It has appeared fairly regularly since then (Table 4) but usually in small numbers as shown by the preponderance of Grades 2 and 3 in fig. 1. It has been unrecorded in 18 years. An exceptional

TABLE 2.

Maximum annual records and range of grades for British Immigrants, 1824-1939.

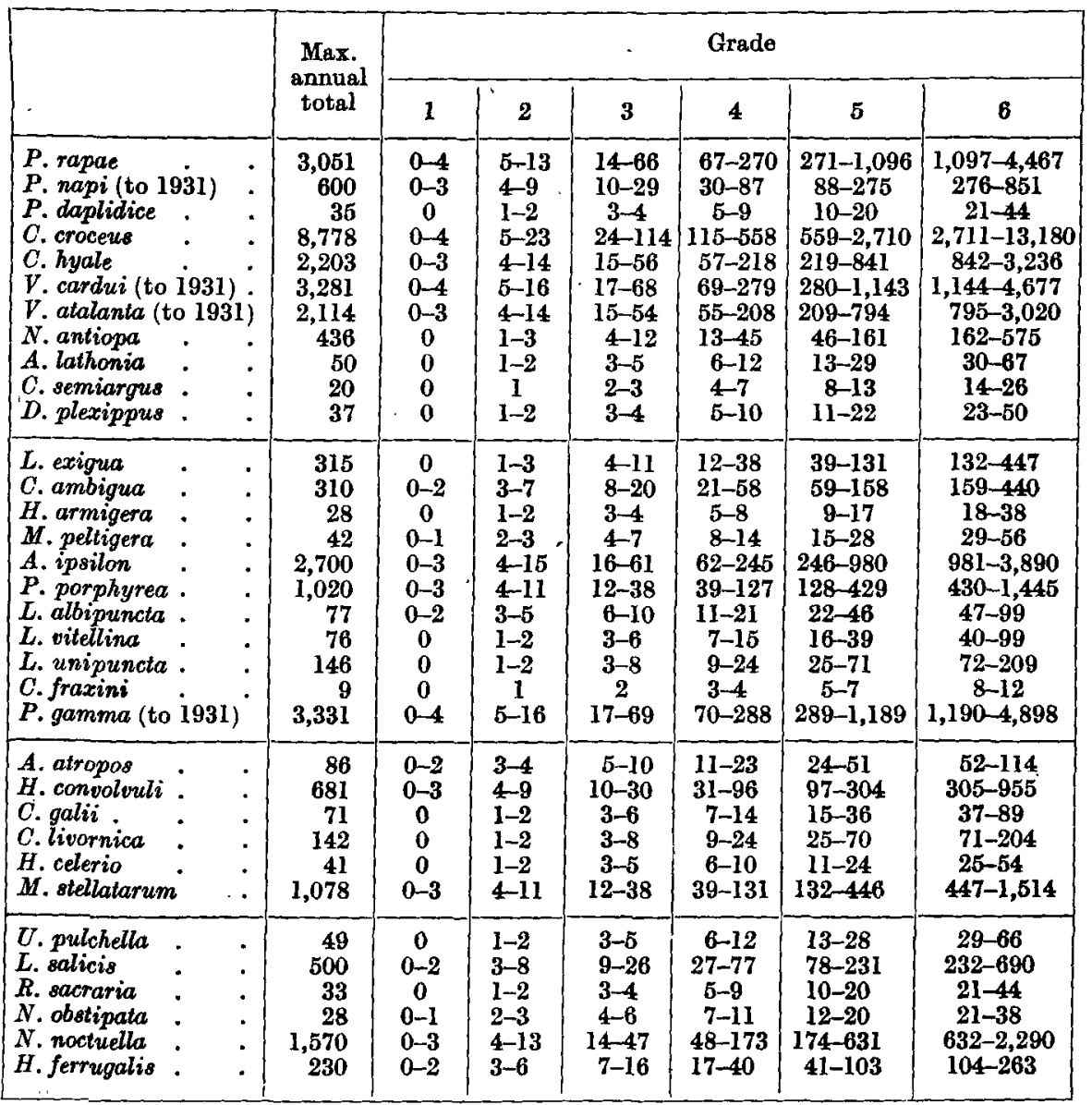


J. A. Downes on studies in the migration of Lepidoptera.

\begin{tabular}{|c|c|c|c|c|c|}
\hline \multirow{15}{*}{ 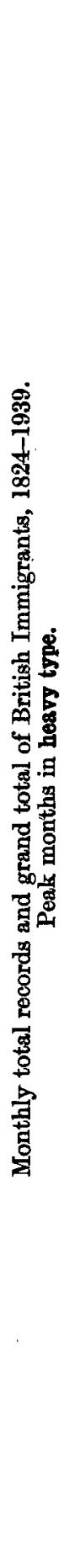 } & 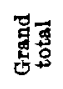 & 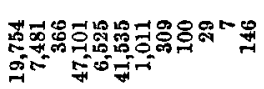 & 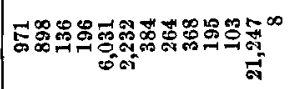 & 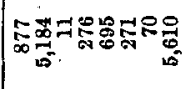 & 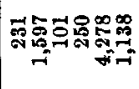 \\
\hline & 总兽 & 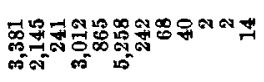 & 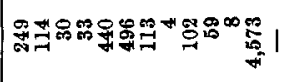 & 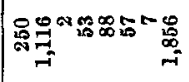 & ำ \\
\hline & $\stackrel{\Xi}{\Phi}$ & -110010011111 & $\mid 11111111$ | 1101 & $\mid-11000$ & 111111 \\
\hline & $\dot{0}$ & 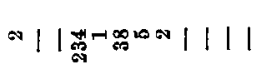 & ||||$|0 \pi||00|$ & $=\infty \mid 1 N$ & $-110-100$ \\
\hline & 宽 & 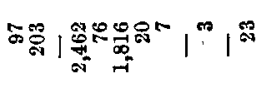 & 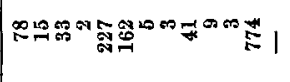 & 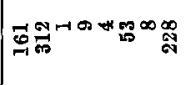 & 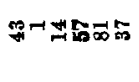 \\
\hline & 䓂. & 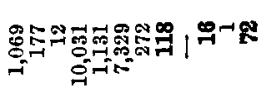 & 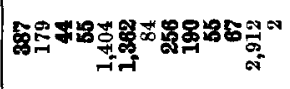 & 궁영 & 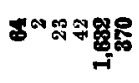 \\
\hline & $\frac{\dot{0}}{2}$ & 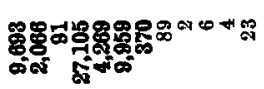 & 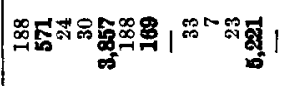 & 发尊 & 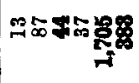 \\
\hline & 量 & 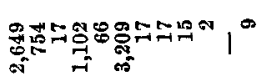 & 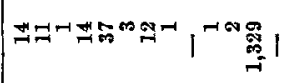 & 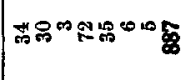 & 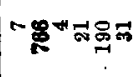 \\
\hline & 昌 & 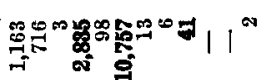 & 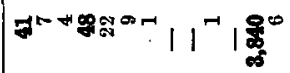 & 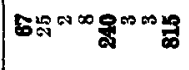 & 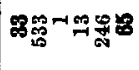 \\
\hline & 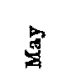 & 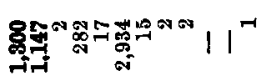 & 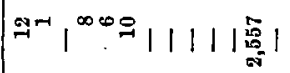 & $\because 111 \stackrel{\mathscr{\sigma}^{\infty}}{\circ}$ & 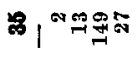 \\
\hline & 安 & 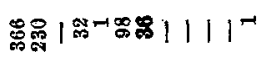 & $-11^{0 x 0-1} \mid 11^{-1} 1^{-1}$ & 0011 1 & 111111 \\
\hline & 峛 & 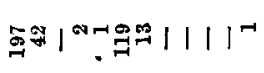 & $\left.\left|-11^{\infty} \boldsymbol{a}\right||| 1^{\infty}\right|^{\infty} \mid$ & $|\pi-1|^{\text {बन }} 1$ क & $\left.|1|\right|^{\infty} \mid$ \\
\hline & 审 & $21101 \Omega^{*}|1| 1 \mid$ & $|11-\infty| 1111111$ & 111100110 & 111111 \\
\hline & 秀 & $\infty n||+\infty|||| \mid$ & $111-111111111$ & 11110110 & 111111 \\
\hline & & 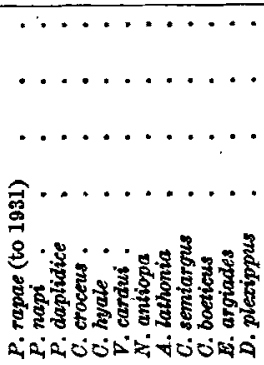 & $\begin{array}{l}\cdots \ldots \ldots \\
\ldots \ldots \\
\ldots \ldots \\
\ldots \ldots \\
\ldots \ldots\end{array}$ & 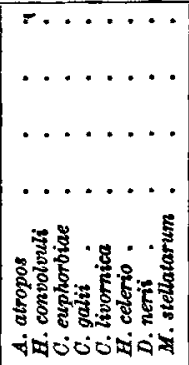 & 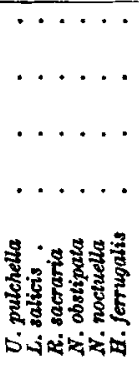 \\
\hline
\end{tabular}




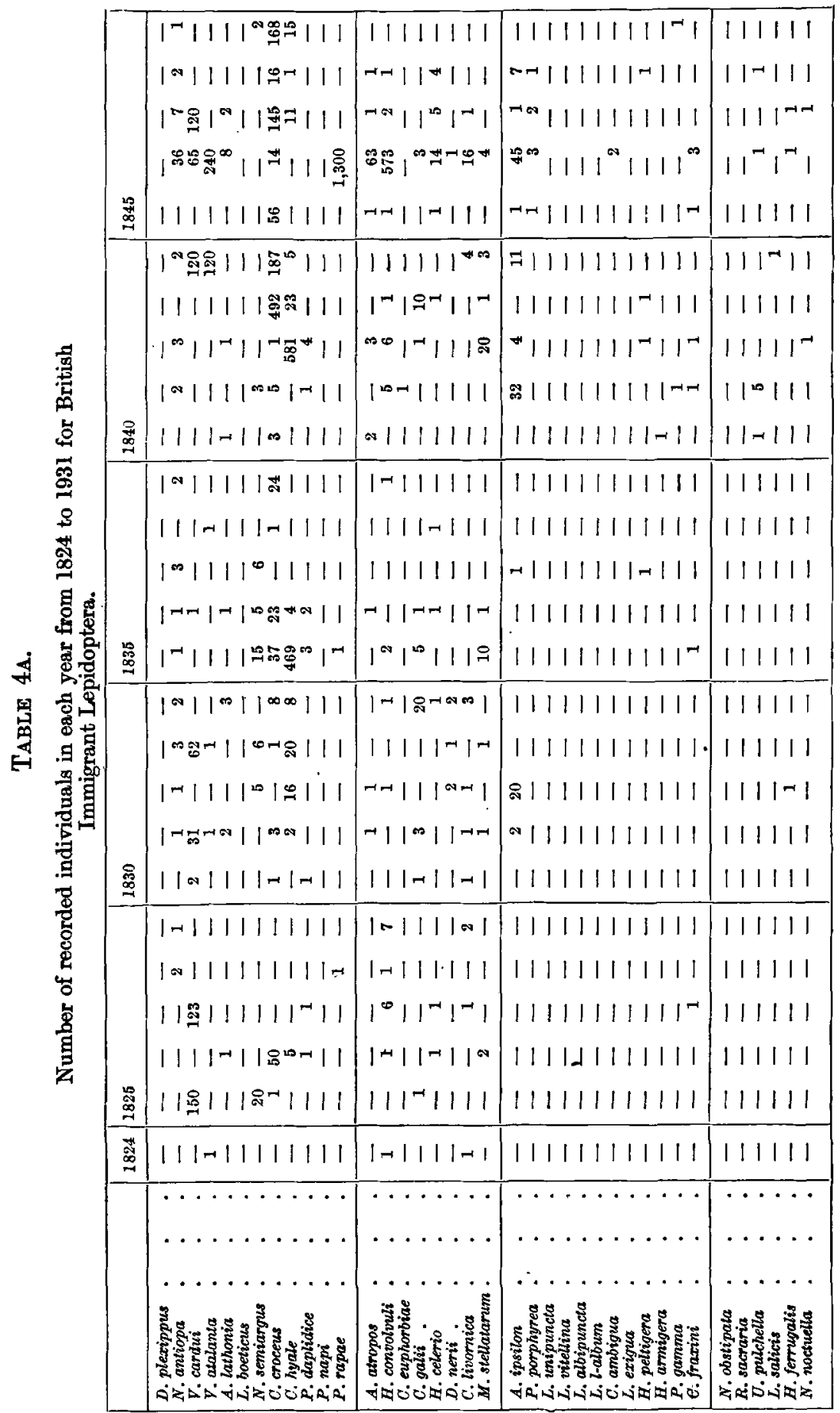




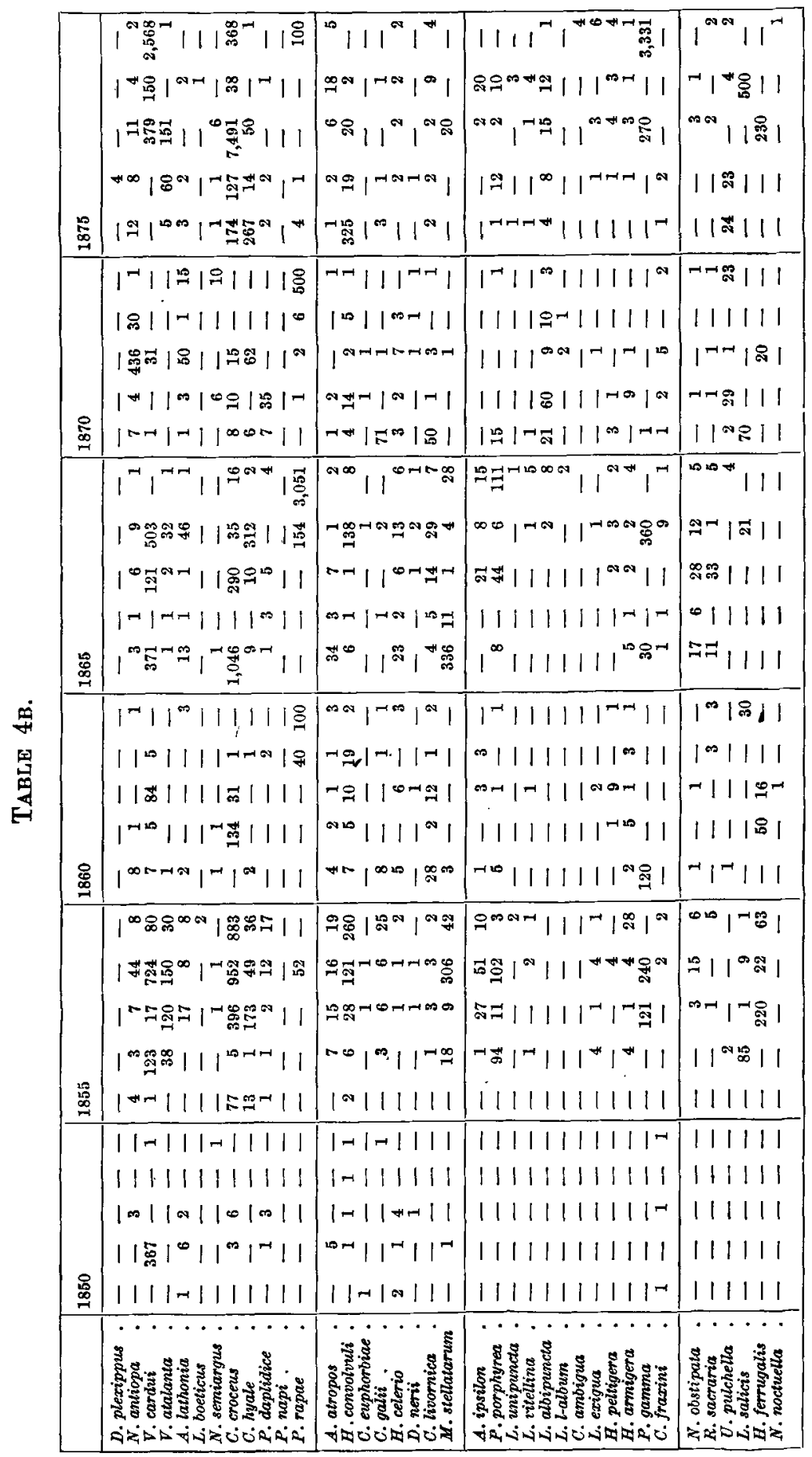




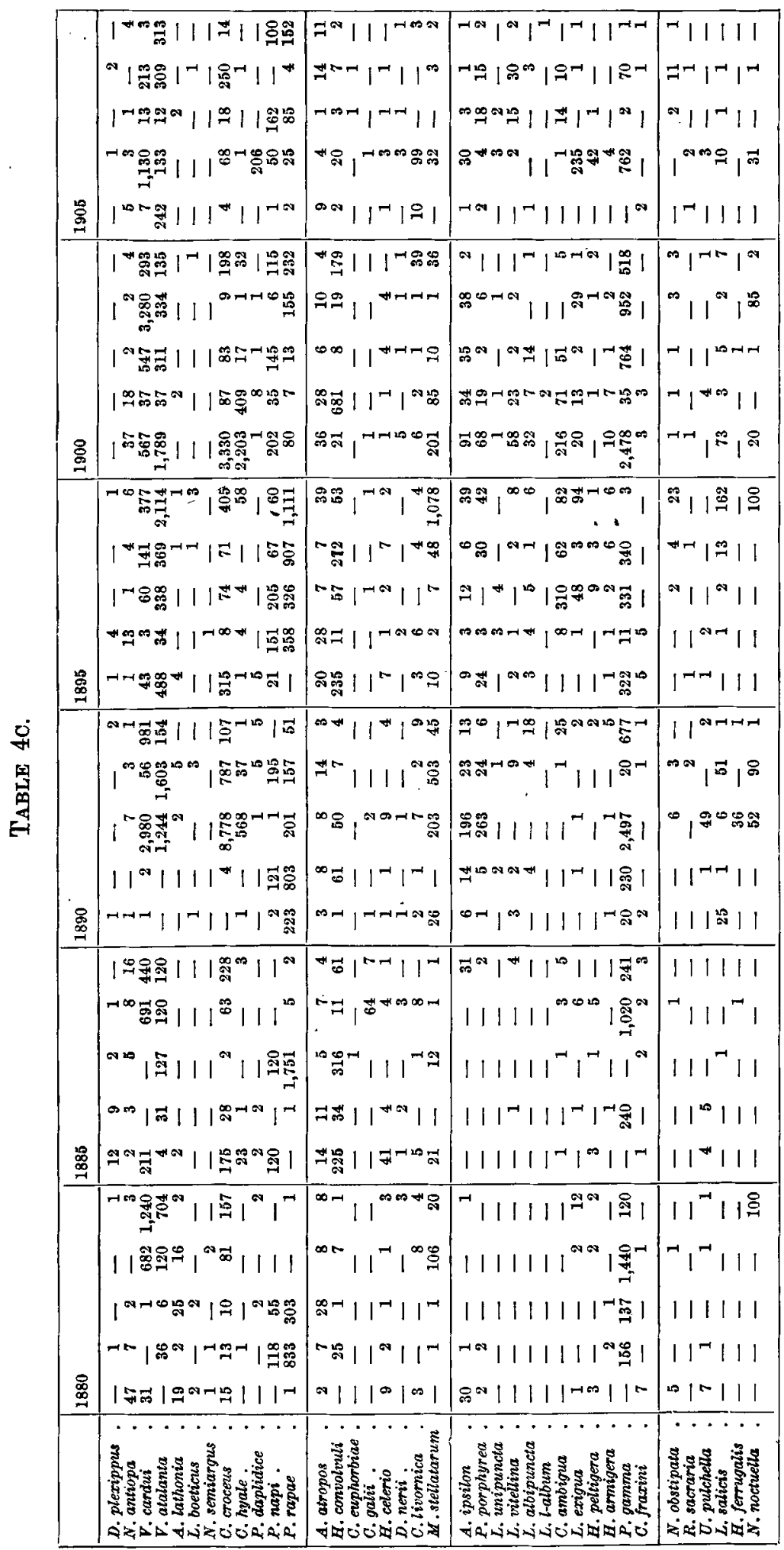




\begin{tabular}{|c|c|c|c|c|}
\hline 吕 & 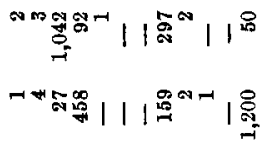 & 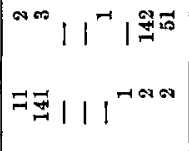 & 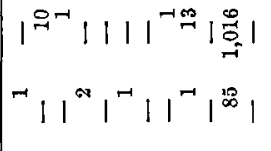 & $\left|1^{-1} 1^{-1}\right|^{-\infty} \stackrel{8}{=}$ \\
\hline & 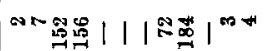 & $m \approx \||||| \vec{\pi}$ & $\operatorname{lm}^{-1}|1| 1||^{2}$ & $|\operatorname{sen} \theta \cos |$ \\
\hline & 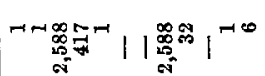 & $\ln 17-\pi+\infty$ & $1^{-1000} \mid 1^{-1}$ & $\underbrace{\infty}, 1$ \\
\hline & 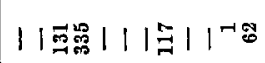 & 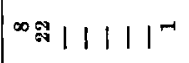 & $\left|1^{-1}\right| 1|1|||_{0}^{\infty} \mid$ & $11111^{\circ}$ \\
\hline & 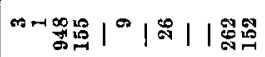 & 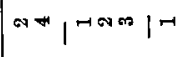 & O $\left.\left.\right|^{-1-1}||\right|^{\sin \alpha} \mid$ & +nos $\mid 1^{-7}$ \\
\hline$\stackrel{200}{g}$ & 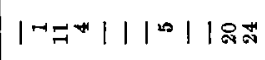 & $\infty n\left|1^{-1}\right|^{-\infty}$ & $1111111111-11$ & $|न| 1||$ \\
\hline & $1^{\infty}$ & $\pi^{\infty}|1|^{\tan x}$ & $\left|1^{\infty} 1^{-1+1}\right| 1^{\infty} \times 1^{\infty}$ & $\left|1^{-1} 1^{-1}\right|$ \\
\hline & ma ్ㅠㅇㅠ & क⿻ ||$^{n}||^{\infty}$ & $\left.\right|^{\infty}\left|1^{-\infty \infty}\right|^{\infty} \mid$ & 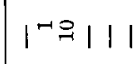 \\
\hline & 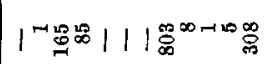 & 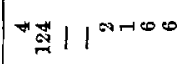 & $\left|1^{\infty \infty 00}\right| 1\left|1^{\text {तn }}\right|^{\text {N }}$ & $\ln || \mid$ \\
\hline & 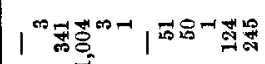 & $+\left.\infty|1|\right|^{\circ}$ & 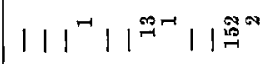 & $\left|1^{-\infty}\right|^{-1} \mid$ \\
\hline 嵒 & 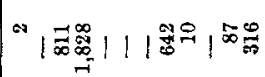 & 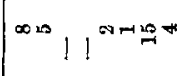 & 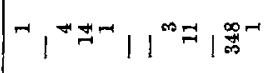 & $11111^{\circ}$ \\
\hline & 1 m & $\left.|\pi-1|\right|^{\infty} \mid$ & F⿻日禸 & 111111 \\
\hline & 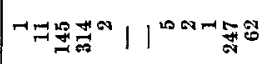 & $-1111^{-1} \mid$ & $-1111111^{-1} 111$ & 111111 \\
\hline & 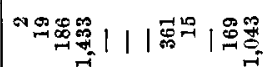 & 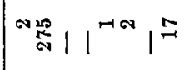 & $111111^{-1} \mid 11^{8-\pi}$ & 111111 \\
\hline & 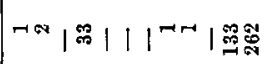 & $\|\left.\left. *||\right|^{-1}\right|^{-1}$ & 111111111111 & 111111 \\
\hline$\stackrel{s}{g}$ & 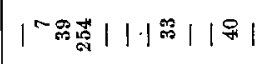 & $\rightarrow \infty 1^{-1}||^{-\infty}$ & $\infty \infty 111111191$ & $11111 \%$ \\
\hline \multirow{9}{*}{$\stackrel{9}{9}$} & 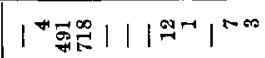 & 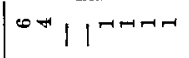 & $\mid-111111111$ 蛋 1 & $-11^{\infty \pi-1} \mid$ \\
\hline & 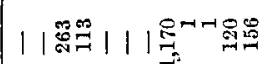 & $\left.|\infty \infty|\right|^{\pi-\infty} \mid$ & केष $\left.1^{+}|1| 1^{\infty}\right|^{-1}$ & $\left.\right|^{\infty} 1^{\cos }$ \\
\hline & $\mid 100$ & 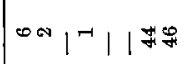 & $\left.\left.\infty \infty\right|^{\infty}\right|^{-7} F^{\infty}|\vec{n}|$ & $011 \times \infty \infty \infty 100$ \\
\hline & $\mid$ న⿻心口 & 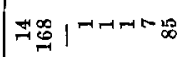 & $\left.\left|P^{\infty}\right|||^{\infty}\right|^{\infty}$ 路 $\mid$ & $-\left.\pi|1|\right|^{\infty}$ \\
\hline & $|\tan \theta-1||| \mid-g$ & $|\infty \infty-|-\infty|1|$ & $111^{\circ} 11111^{-17} 1^{-17}$ & 111111 \\
\hline & & & & \\
\hline & & & 10 & . \\
\hline & 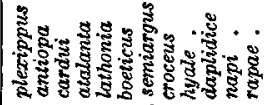 & 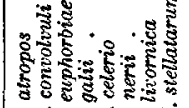 & 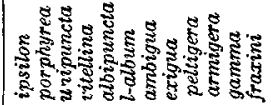 & 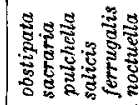 \\
\hline & 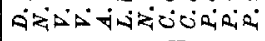 & 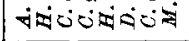 & 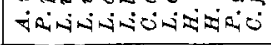 & संखing \\
\hline
\end{tabular}

TRANS. R. ENT. SOC. LOND, 92. PART 1. (JULY 1942.) 
year occurred in 1872 , when there were 436 recorded. The next highest total was 47 in 1880 . Here is a clear instance that although the number of observers has certainly increased since 1872 , the records have not shown any corresponding increase, which suggests that a high proportion of the insects has been recorded, and that this number is largely independent of the number of observers. Even after 1931, when the S.E.U.S.S. began an intensive search for migrants, the records have not shown any increase.

The species has occurred in Britain throughout the 12 months, August and September being the peak months (Table 3). It is outstanding among the British migrant butterflies in that most of the records are from the eastern portion of Britain, from Orkney to the south coast of England, strongly suggesting that the migrations come from the east, perhaps from Scandinavia.

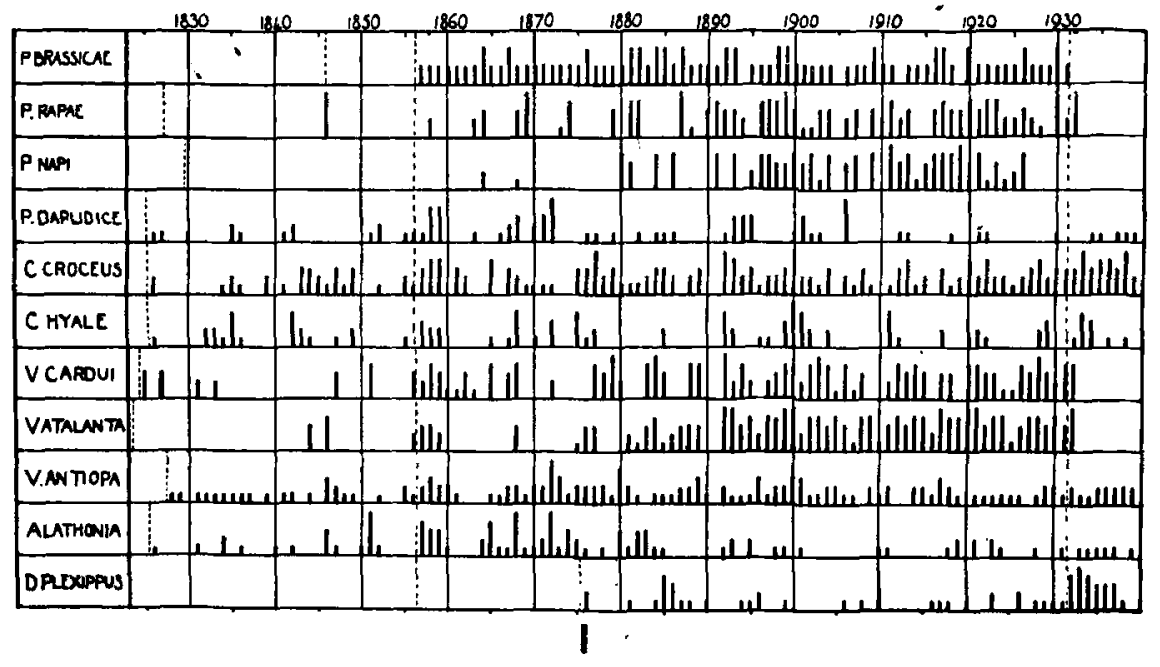

Fig. 1.-Annual abundance, in six grades, of British Immigrant Butterflies, 1824-1931.

Vanessa cardui (fig. 1).

The first records to come into this survey were in 1825. From that date to 1887 there were 30 years with no records, but since 1887 there has not been a year without mention of the species. It has occurred in all parts of Britain and in every month of the year (Table 3). There are, however, very few records during the winter months December to February. The grand total of records was 41,535 insects, and of these only 18 were reported in the winter months, in 11 out of 115 years. This is less than 1 in 2000 of the recorded individuals and even this probably represents too high a proportion, as "Painted Ladies" in winter are much more likely to attract attention than in summer. The summary of monthly totals, Table 3, shows two peak months, June and August, indicating that there are either two immigrations or that the second peak marks the brood resulting from the first immigration.

A contingency table giving the relation between " earliness" and "abundance" is shown in Table 5. The " early" migrants are considered as those occurring before June, and an " abundant year " is taken as being Grade 5 or 6 .

In each square the observed results are to the upper left and the expected, 
on the hypothesis of no relation, to the lower right. In all subsequent contingency tables this arrangement will be followed.

The evidence shows that there were 31 years of abundance and 44 not abundant. Also, in 39 years the immigrants were early and in 36 they were late. If there were no correlation, in 16.1 years "abundant" would occur with " early," and in 21.1 years " late" would occur with " not abundant." The observed values show that " abundant and early" occur together in 23 years, and "late and not abundant" in 28 , both considerably higher than the calculated. The values for "late and abundant" and "early and not abundant" are correspondingly lower than expected. The $\chi^{2}$ test of significance calculated from these differences is $9 \cdot 0$, which gives a probability which is smaller than 0.01 , a result which is certainly significant; otherwise, that there is less than 1 chance in 100 that this result has arisen by chance. The infereace is that in year early appearance of $V$. cardui would most likely be followed by a season of abundance, and that a late appearance would be followed by a season of small numbers.

Table 5.

Relation between earliness and abundance in $V$. cardui (1865-1939).

\begin{tabular}{|c|c|c|c|c|}
\hline & & Abundant & Not abundant & Total \\
\hline Early & $\cdot \quad \cdot$ & $\begin{array}{ll}23 & 16 \cdot 1\end{array}$ & $22 \cdot 9$ & 39 \\
\hline Late & . & 14.9 & $21 \cdot 1$ & 36 \\
\hline Total. & . & 31 & 44 & 75 \\
\hline
\end{tabular}

This result might be explained by assuming that Britain is on the fringe of the distribution area of $V$. cardui, the area of origin being north Africa. In years of abundance, the insects would spread farther afield more rapidly than in other years, and Britain would receive migrants earlier in the year, and would be well inside the fringe of the distribution area of the insect. As a result, the intensity of insects would be greater in such years. Also, the second brood, mainly homebred and dependent on the spring immigrations, would be increased by an early and abundant invasion.

\section{Vanessa atalanta.}

This is a regular migrant and has been recorded continuously with only a two-year gap since 1881. The relative abundance is shown in fig. 1 .

For the period 1857-1931 there occur 19 years in Grade 5, 17 in Grade 4, and 19 in Grade 1. This last includes 13 years in which no records were found, which, however, cannot be taken to mean that no insects occurred as the species is generally common. If these years of no records are excluded from the total, it will be seen that the species occurs most frequently in intensity corresponding to Grade 4 and 5.

The annual totals in this species were arrived at by a process little short of guesswork. Its justification lies in the fact that the numbers obtained are not regarded in any way as being absolute and are used only for comparison 
of abundance. An arbitrary figure of 30 was taken to interpret such descriptive accounts as " common," "frequent " or " numerous," and 120 to interpret "abundant," "very common" or any such superlative description. If a numerical estimate were given, it was utilised. The totals so obtained did not give rise to any anomglous findings.

These arbitrary numbers were not included in the table of occurrences month by month (Table 3).

From 1824 to 1875 the butterfly was recorded in only 16 years, but since 1875 there were only 4 years when it was not mentioned. Since 1892, the annual totals have all been higher than the range of Grade 1. The records since this date would seem to be a truer estimate of the occurrences of the species.

\section{Cyaniris semiargus.}

The records of this insect are unusual in that the largest number reported in any year (20) was in 1825. It has only occurred in 25 years out of 115 (Table 4).

The majority of the records are for June, the range being from May to August (Table 3).

\section{Cosmolyce boeticus.}

This insect is another sporadic visitor. As shown in Table 4, it was recorded in 1859 , and has been recorded in only 13 years since. The largest total taken in any year was 3 , with the possibility that 9 were observed in 1926 since the records show the capture of three specimens in Torquay, Devon, in September and it was also seen there on six occasions during the month. The records are mainly from the south of England.

The numbers were not sufficiently large for the inclusion of this species in the correlations (see later).

\section{Everes argiades.}

This is a very rare visitor to Britain. Only seven records have been found. The first was that of two taken in 1874 at Frome, Somerset. These specimens, a male and a female, are now in the Dale Collection, Hope Museum, Oxford. This point is worth mentioning, since in 1885 three specimens were captured and were reported as being the first British specimens. The only other captures were in 1921 and 1931. The insect has been taken in Somerset, Dorset and Hampshire and in Sussex; four in August, one in September and two without information as to the month of capture.

This species has not been included in the correlations.

\section{Argynnis lathonia (fig. 1).}

The Queen of Spain Fritillary is about as frequent and as numerous as $P$. daplidice. The longest absence of records was the period of eight years between 1902 and 1910. The highest annual total was 50 insects in 1872 (Table 4). The records range from May to November, with August and September as the months of maximum abundance (Table 3). Most records are from South and South-east England, with a doubtful record in 1834 from Northumberland. One was reported from Scarborough in 1868. 


\section{Colias croceus (fig. 1).}

The first record to come into this survey was that of a capture by B. Morris at Worcester in 1825. The following year it was taken in abundance at Charmouth, Dorset. In the period from 1825 to 1939 , i.e. 115 years, there were only 15 years when the species was not recorded, and 15 years when it was abundant, that is, Grade 5 or 6 . From fig. 1 it will be seen that the most frequent grade indices are 3 and 4 , indicating that a medium abundance of this species is usual.

The species tends to be most abundant during August, as shown in Table 3, but has been reported as early as February in 1857 and 1935, and as late as December in 1878 and 1896. The rise in numbers to a peak in August indicates a steady influx of migrants culminating in the August abundances, rather than a spring invasion followed by a late summer invasion. The only years in which there is clear evidence of two distinct immigrations, or of one invasion and a local bred brood, were 1877 and 1938, in which cases about nine hundred more insects were recorded in June than in July, while in August the numbers recorded were over 5300 and 2400 respectively more than in July.

Table 6.

Relation between earliness and abundance in Colias croceus, 1830-1939.

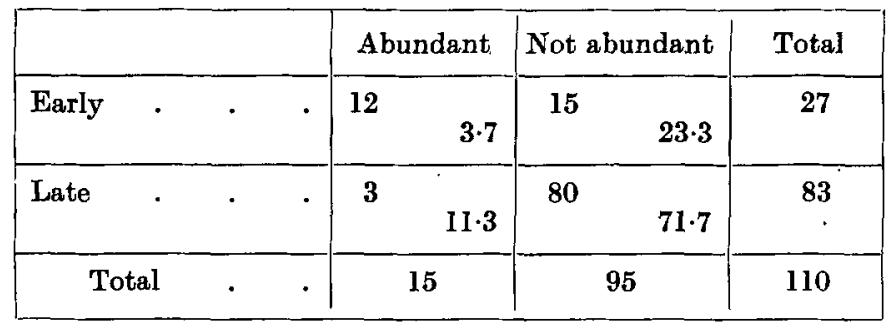

An attempt was made to see if there was in this species any relationship between the appearance of early spring migrants and years of abundance. Early spring migrants were regarded as being those occurring before June, and years of abundance those indexed by 5 or 6 . Table 6 shows a contingency table to illustrate the result.

In 110 years, from 1830 to 1939 , there were 27 years with early immigrants and 83 with late, and 15 years of abundance and 95 of non-abundance. In the absence of correlation it would be expected that 15/110 of the "early" years would be abundant and 95/110 would be " not abundant." The expected totals are shown. $\chi^{2}$ is 7.2 and is significant at 0.01 level. The observed totals of "early occurrence with abundant" and "late with not abundant" are significantly higher than the expected, and the observed totals of "late and abundant" and "early and not abundant" significantly lower. The inference is that early spring migrants are in general forerunners of a large immigration, and that a late appearance precedes a season with small numbers. Most of the records are from the south and south-east coasts and indicate that $C$. croceus arrives via France. 
Colias hyale (fig. 1).

This species was recorded as being taken in 1826. Since that year it has appeared fairly regularly (see Table 4) but there have been several groups of years without records. Thus, from 1827 to 1830 inclusive, and from 1837 to 1841,1850 to 1854,1861 to 1864 (only 1 record), 1878 to 1884 (only 1 record), 1905 to 1910 (only 2 separate records), and 1923 to 1927 , the species was not recorded. These periods of absence do not show any obvious periodicity. Grades 5 or 6 have occurred 9 times, and complete absence of records 45 times, out of the 114 years between 1826 and 1939. The species has been most abundant in Britain in August, and shows very little evidence of a double immigration (Table 3). In 1900 there were records of 36 insects in June, 15 in July, and 1758 in August. In 1901 there were 11 in June, 1 in July and 307 in August. Excluding these two years from the monthly summary, Table 3, it will be seen that the numbers show a steady increase from March and April (one record each) to August. There is one record of a capture as late as November in 1912.

TABLE 7.

Relation between earliness and abundance in Colias hyale, 1826-1939.

\begin{tabular}{|lrrr|rr|rr|c|}
\hline & & & \multicolumn{2}{|c|}{ Abundant } & Not abundant & Total \\
\hline Farly & $\cdot$ & $\cdot$ & $\cdot$ & 3 & 0.8 & 7 & $9 \cdot 2$ & 10 \\
\hline Late & $\cdot$ & $\cdot$ & $\cdot$ & 6 & & 98 & $95 \cdot 8$ & 104 \\
\hline Total & $\cdot$ & $\cdot$ & $\cdot$ & \multicolumn{2}{|c|}{9} & \multicolumn{2}{|c|}{105} & 114 \\
\hline
\end{tabular}

The records are mainly from the south and south-east counties, and indicate that the insects come via France.

A contingency table, Table 7, was drawn up on the lines of that of $C$. croceus and shows that the figures observed are not very different from the calculated ones. The test for significance shows that $\chi^{2}=4 \cdot 4$, which is significant at $1: 20$ but not at $1: 50$. It is therefore possible, but not certain, that $C$. hyale appears earlier in its years of greater abundance.

\section{Pontia daplidice (fig. 1).}

This species, while never numerous in Britain, appears fairly regularly. The longest absence from Britain since 1826 (the first record collected) was the period of 8 years from 1844 to 1851 . The total number of insects recorded between 1826 and 1939 was 366 . This includes one record for 1906, where it was stated that over 200 were seen on the Dover cliffs. Apart from this, the highest annual total was 35 in 1872, the year when $N$. antiopa was also very abundant.

Most of the records are from south and south-east England. The most northerly was one in 1852 from Whittlesea Mere, near Liverpool. It is most likely that this insect arrives from France.

The monthly totals, Table 3, show that the earliest records were in May and latest in October, with August as the month when most occurred. 
The Cabbage Whites.

The records of the three species $P$. rapae, $P$. napi and $P$. brassicae are complicated by the fact that they are normally present in numbers in Britain and tend to be reported only in the years of absence or of special abundance. In the case of $P$. brassicae, this is particularly noticeable.

Pieris brassicae (fig. 1).

The records of this species are not very reliable. In assessing the group indices of the years, the records were scanned, and were roughly placed in three categories : scarce, moderate and abundant; approximating to grades 2 , 4 and 6 . Any absence of records was regarded as indicating a moderate abundance. This method was not expected to be of great value, but on carrying out correlations with its related species, $P$. rapae and $P$. napi, it was found that the results obtained, although not as high as might be expected, were significant, and pointed to an observable fact that these species tend to be abundant together (see p. 257).

\section{Pieris napi (fig. 1).}

The records of $P$. napi are not of much use for this survey until 1880 , since when they have been fairly consistent. Fig. 1 shows that the most frequent grades are 4,5 and 6 . If the 10 years without records are not counted, the preponderance of the higher grades is more obvious. The species occurs almost everywhere in Britain and apart from one record, in January 1860 , appears to be limited to the period March to October, with a peak in August (Table 3).

\section{Pieris rapae (fig. 1).}

The records of $P$. rapae appear to be consistent since 1857, with the possible exception of 15 years in which there were no records (Table 4). It is very unlikely that in these years there were no $P$. rapae present.

The general abundance can be seen from fig. 1 , which shows that if these 15 years without records are not considered, the Grades 3,4 and 5 are the most frequent. The species has occurred in all months of the year, and all over Britain.

\section{The Hawk-Moths (fig. 2).}

The distribution of the hawk-moths in Europe suggests that the British migrants come from the Mediterranean region or from north Africa. Little information can be collected of their flight directions because most of the captures are taken at night over attractive flowers or at light, so that no positive evidence can be provided as in the case of $V$. cardui or $P$. brassicae.

\section{Acherontia atropos (fig. 2).}

This is one of the most regular British migrant hawk-moths. Since 1831 it has been unrecorded in only 17 years, and since 1857 , in only 2 years. It has always been an insect which attracted attention and is usually recorded if seen by any naturalist.

A. atropos has occurred from March (1 specimen) until November, with September and October as the peak months (Table 3). There is a small secondary peak in June, which might suggest that there are two immigrations. 
In this survey the larval and pupal stages have not been included. There have been more reports of larvae than of adults, but since the appearance of numbers of larvae throw little light on the numbers of the parents, they were omitted from this work. The most frequent grades are Grades 1 to 3, showing the tendency of the species to occur usually only in small numbers (fig. 2).

\section{Herse convolvuli (fig. ${ }^{2}$ ).}

This hawk-moth has been reported in Britain with few intervals since 1824 (Table 4). It has been unrecorded in 14 years between 1824 and 1939 .

It has occurred in all months except January, February and May, with September as the peak month (Table 3). The records of occurrences are distributed all over Britain with a preponderance in the south and southeastern part of England.

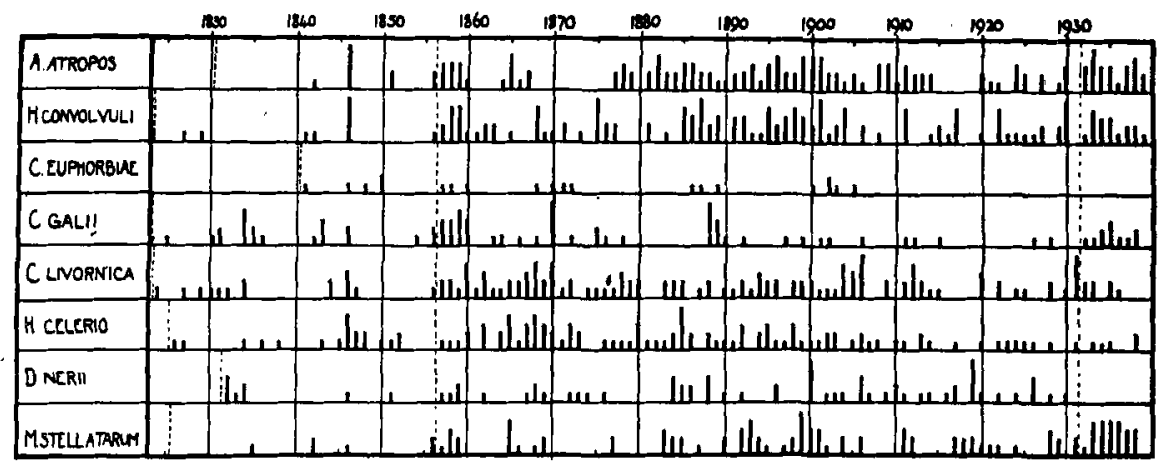

\section{2}

Fic. 2.-Annual abundance, six grades, of British Immigrant Hawk-Moths (SpHINaIda E), 1824-1939.

From fig. 2 it can be seen that from 1857 to 1931 Grades 1, 2 and 3 were most frequent. In only three of these years was the species unrecorded. Although it is a very frequent visitor, it occurs in small rather than large numbers.

The records since 1931 show no marked difference from those of previous years, indicating that the numbers of insects recorded are not limited by the numbers of observers.

\section{Celerio euphorbiae.}

This species is a very rare visitor to Britain. From 1841 (the first record) to 1940 , we have found records of only 11 adults and 33 larvae. The numbers were too small to include this species in the correlations given later. The months of occurrence of the adult are June to October, but 2 larvae were taken in March 1907. The records occur as far afield as Banffshire in Scotland, Cheshire, Norfolk and Somerset.

\section{Celerio galii (fig. 2).}

This species has been taken more frequently as a larva than as an adult. The first record since 1824 was one taken in 1825 . 
- It has appeared at intervals since then for periods ranging from a single year to a maximum of seven years from 1854 to 1860 , and eight years from 1932 to 1939. The largest number of adults recorded in any one year was 71 in 1870 . There were also 17 larvae recorded in the year. In 1888, the species was again abundant, when 64 adults were recorded : in that year, over 1100 larvae were recorded. After the 1870 immigration none was recorded in 1871 and only one in 1872. After the 1888 immigration, when so many larvae occurred, there were 7 adults and 30 larvae recorded in 1889 and only 1 adult in 1890 . It is possible that the 1888 immigration left progeny which became adult in 1889 , but did not persist.

From Table 4 it can be seen that since 1857 it has been absent more frequently than present, and that in the years, when it has occurred, 1 or 2 specimens is the most frequent number.

The species has occurred over Scotland and England. The adults have been most abundant in August, but have occurred from June to October. Apart from one record of 10 larvae in March 1892, the larvae and pupae have occurred also from June to October with peaks in August and September (Table 3).

D. galii is an example of a species that is capable of reaching Great Britain from Europe early enough in the year to produce a brood of larvae. The onset of winter, however, is so rapid that either the larvae do not reach maturity, or, reaching maturity, are unable to hibernate as adults.

\section{Hippotion celerio (fig. 2).}

Though not numerous, this species has occurred fairly frequently in Britain, and has been taken throughout the country, most of the records being from the south of England.

It has occurred in all months except January and February, with September as the month of maximum abundance (Table 3). Since 1857 there have been 20 years in which the species did not occur. The years of maximum abundance were 1865, with 27 insects, and 1885 with 41 insects (Table 4).

Fig. 2 shows that the most frequent grade is Grade 2, i.e. 1 or 2 individuals.

\section{Daphnis nerii (fig. 2).}

This hawk-moth has occurred sporadically in Britain as adult and larva. In 1832, four adults and two larvae were taken. It has been absent in 57 years out of the 100 years from 1832 to 1931 , and the maximum total in any year is 6 in 1919 . Occurrences of $D$. nerii have been reported from Aberdeenshire to Devonshire, including Lancashire, Yorkshire, Midlands, Norfolk and S. and S.E. England.

It has occurred from May to October, with September as the peak month (Táble 3).

Celerio livornica (fig. 2).

This species has been fully dealt with by Grant (1937) and will not be discussed here except in its correlations with other species (p. 257).

Macroglossum stellatarum (fig. 2).

This has occurred in every month of the year, the period of maximum abundance being June to September with a slight peak in July. The appear- 
ance of the moth during the winter months suggests that in isolated cases it may survive throughout the winter. That it does not establish itself in any numbers after such hibernation can be inferred from the contingency table, Table 8.

This table tests the assumption that abundant years follow winters in which the moth occurred. Abundance is taken as being a year in which Grade 5 or 6 occurred, and winter is taken as being November, December, January and February.

\section{TABLE 8.}

Relation between years of abundance and records in the previous winter for Macroglossum stellatarum, 1865-1939.

\begin{tabular}{|c|c|c|c|}
\hline & Abundent & Not abundant & Total \\
\hline In winter & 2 & $10 \cdot 88$ & 12 \\
\hline Not in winter & $5 \cdot 88$ & $57 \cdot 12$ & 63 \\
\hline Total & 7 & 68 & 75 \\
\hline
\end{tabular}

The numbers are almost exactly what would be expected if there was no relation between abundance and appearance in the previous winter. There is an indication that years of abundance are followed by occurrences of the insects in the winter months as the following contingency table shows (Table 9). Years of abundance are compared with occurrences of the insects in the following winter months. The actual occasions when it occurred in winter are 5 and the expected, $1 \cdot 1$. The value of $\chi^{2}$ is $13 \cdot 4$, which is highly significant. However, these numbers are too small for the result to be regarded as a proof.

\section{TABLE 9.}

Relation between years of abundance and records in the following winter for $M$. stellatarum, 1865-1939.

\begin{tabular}{|c|c|c|c|c|}
\hline & & Abundant & Not abundant & Total \\
\hline In following winter & - & 5 & 10.9 & 12 \\
\hline Not in following winter & • & 2 & $57 \cdot 1$ & 63 \\
\hline Total . & 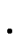 & 7 & 68 & 75 \\
\hline
\end{tabular}

There is a high proportion of Grade 1 as shown by fig. 2 . In 19 years out of the 38 in Grade 1, the species was not reported. It can be seen that this species tends to occur more frequently in small numbers.

Noctuids.

Agrotis ipsilon (fig. 3).

This insect is generally regarded as being native in Britain but supplemented by immigrations. The records show that it was found in 1831, and 
in the 109 years, 1831-1939, it has been recorded in 64 years, and has not been recorded in 45 years (Table 4 ).

The records reflect the activities of the South-Eastern Union of Scientific Societies in that, since 1931, they show two years of extreme abundance, greatly in excess of anything that had been previously recorded.

Well over half of the records are for August. The only months for which records were not obtained were January and December (Table 3).

\section{Peridromia porphyrea (= saucia) (fig. 3).}

This is an indigenous species that had not been reported in large numbers in Britain until 1938, when over a thousand insects were recorded. Since 1857, there has been a gap of 7 years in the records between 1882 and 1888,

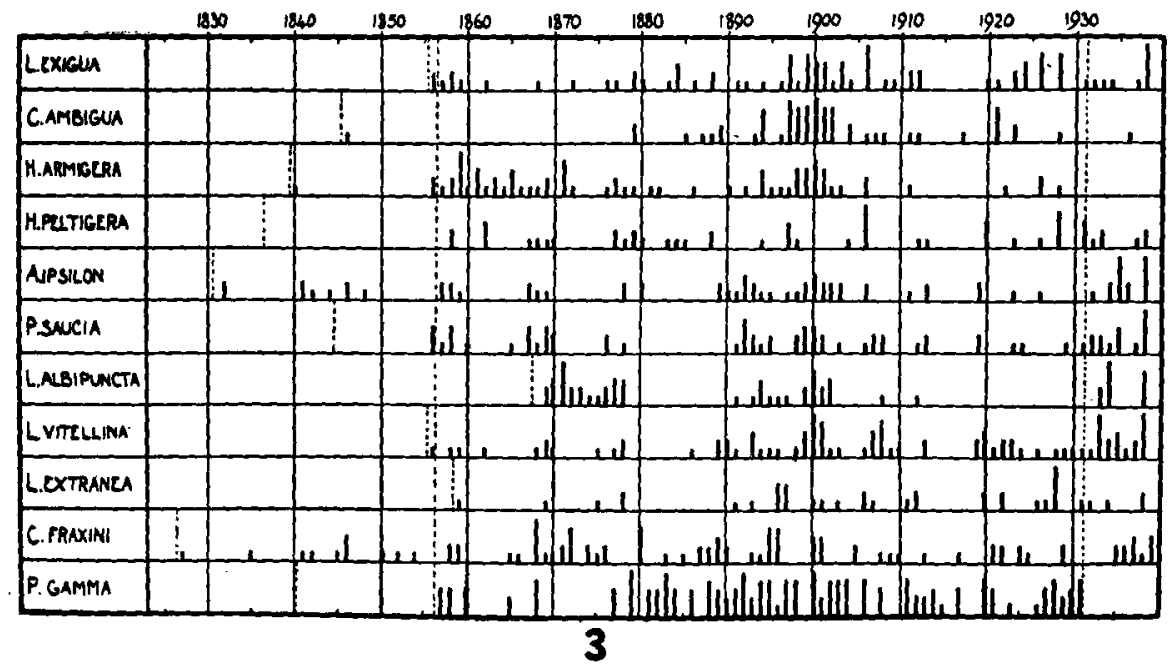

Fia. 3.-Annual abundance, in six grades, of British Immigrant NocturdaE, 1824-1939.

but apart from this the longest gap is 3 years. There is no evidence of a double peak in the monthly records. The month of greatest abundance is September (Table 3). It has occurred throughout Britain.

\section{Leucania unipuncta (= extranea) (fig. 3).}

This is the "Army Worm" of America, where it does great damage to crops in some years.

The first record in Britain appeared in 1859. It has occurred sporadically since then, having been present in 24 years out of 81 . There is little information in the records as to the months of maximum abundance. Table 3 shows that September has the highest total, but, since the year 1928 contributes over half of the September totals, most of those of October and November and all of those of December, not much can be inferred from the remaining years.

Captures are mainly from the south and south-west of England, from South Wales and the south of Ireland. 


\section{Leucania vitellina (fig. 3).}

This species has occurred frequently but in small numbers since 1856 when it was first recorded in Britain. It has been present in 47 years and absent in 37 years. The years of greatest abundance were 1900, when 58 specimens were recorded, 1933 with 41 specimens and 1938 with 76 specimens.

The seasonal range is short. Apart from two records in 1869 and 1870, it has occurred in August, September and October only, with September as the peak month (Table 3).

On 26th September, 1938, 2 specimens were recorded flying to the south at the Sunk Light Vessel, off Felixstowe, Suffolk.

\section{Leucania albipuncta (fig. 3).}

The first certain record of this insect in Britain was that of a capture at Folkestone, Kent, in August 1868, although there is a report of one captured in " 1862 or 1864 at Yaxley" (? Hunts). The records show an unusual fluctuation (Table 11). From 1868 to 1879 the species occurred every year; from 1880 until 1890 there were no records; from 1891 until 1905 there were only two years in which it did not occur, and from 1906 to 1931 it occurred in only 4 years. Since 1931 it has occurred in 5 years, and has been unrecorded in 3 years, despite the activities of the Insect Immigration Committee of the S.E.U.S.S.

These gaps in the records are not explained by gaps in the occurrences of periodicals, which indicates that had there been occurrences during these years, there was no lack of observers or of opportunities for publishing observations.

It has occurred in Britain from June to October, the month of maximum abundance being August with 169 individuals and September with 84 (Table 3). There is evidence here of a single immigration arriving during the summer months and disappearing before winter.

The species has occurred mainly in south and south-east England, the most northerly record being one from the Norfolk Broads in 1895 .

\section{Leucania loreyi.}

This is a very rare immigrant to Britain. Only six specimens have been recorded since 1862, when two were recorded in October. Two have been taken in September, three in October and the month of capture of the other was not given. The records are from Sussex, Devon and Co. Cork, Eire. The numbers recorded are too small to include in the correlation tables.

\section{Leucainia l-album.}

Until 1933-1939, this rare immigrant had been recorded in only six years in Britain, the total number of insects being nine. Since 1932, this has been brought up to 264, of which one occurred in July, 256 in September, three in October and four were without the month being stated (Table 3). The records are mainly from the southern counties of England. This species also is not included in the correlation tables.

\section{Caradrina ambigua (fig. 3).}

In 1879 there was a record of four specimens being taken at Brighton which were said to be the first British specimens. However, a previous record existed of two specimens taken at Brixton in 1846. 
Since 1879 , it has been unrecorded in 36 years and present in 25 years. The maximum occurrences were in the years 1879 and 1900 (Table 4). During the period 1896 and 1902, it was recorded in several months during a year, but since then has been recorded in only one month of any year (Table 3 ). The earliest occurrence was in May and the last occurrence in October, with most in August.

All records in Britain are from the south coast, in the counties of Hampshire, Sussex and Kent.

\section{Caradrina exigua (fig. 3).}

This was first recorded in Britain in 1856 and has occurred at intervals since then. The longest unbroken series of records was for the 9 years from 1896 to 1904 , and the next longest of 4 years from 1856 to 1859 inclusive (Table 4).

The sporadic occurrence strongly suggests that it is a migrant. The months of greatest abundance were August, September and October, with a peak in September (Table 3). Apart from the years 1906 and possibly 1938, there is no evidence of a double peak of abundance in the same year. In these two years, more insects were recorded in June than in July. Most of the records are from the south of England, but there are also records from Berwick and from Hartlepool.

\section{Heliothis peltigera (fig. 3).}

This has not appeared very frequently. in the records. It was recorded in.1837. From then to 1939 , a period of 103 years, it was present in 52 years and absent in 51 years. There are periods ranging from one to nine years when it was not recorded (Table 4). Larvae have been recorded in large numbers from May to September.

The monthly totals show a peak in June and another in September, and the species has occurred from January to October, though the January to March records are obtained from two years only (Table 3).

This species is able to produce a brood during the summer months, but there is very little evidence to show that it can maintain itself in Britain during the winter. There are no records of the larvae or pupae before July or after October. It would appear from the records that it should be regarded as a rare immigrant rather than as a resident.

\section{Heliothis armigera (fig. 3).}

This rare immigrant was first recorded in Britain in September 1840. It was not recorded again until 1856. From 1857 to 1903 it was absent in only 15 years, but from 1903 to 1939 it has been reported in only 5 years (Table 4). It was most abundant in 1859 when 28 specimens were recorded. The activities of the Insect Immigration Committee have not influenced the records in any way.

It has been seen as early as June in 3 years, as late as October in 8 years, and the months of maximum records are September and October (Table 3). There is no evidence of a double immigration:

The larva of $H$. armigera is the "Cotton Boll Worm" which damages corn and cotton crops in America and in Africa. 
Plusia gamma (fig. 3).

This is a well-known migrant moth, and it has received much notice in the literature since 1879 , when, together with $V$. cardui, it occurred in extreme abundance throughout Britain. Before 1879, it was mentioned in 9 years only, of which 3 years had a report of one specimen each (Table 4).

The records of $P$. gamma include many descriptive accounts of the numbers seen. The same system of transforming words into figures was used as for V. atalanta, where such terms as "very common," abundant" and "swarming "were given the arbitrary figure of 120 ; "common," "very frequent" and "numerous" were given the figure of 30 ; whenever actual numbers were given they were used as given. Although this system is so arbitrary, it has provided a method of comparing abundances which appears to give consistent results. It has long been known to collectors that $P$. gamma is usually abundant when $V$. cardui is abundant. A correlation of the occurrences of these two species gives a result significant at the 0.01 level (see Table 33).

The monthly totals have been made up to 1932 , after which the records became greatly increased owing to the activities of the S.E.U.S.S. These totals (Table 3) show that there are two peaks of abundance, one in May and June and the other in August and Séptember. This fact could be explained either as a double immigration in the year, or as a spring immigration followed by the resulting summer brood. The occurrence of a preponderance of spring flights to the northward and of autumn flights to the south for the years 1933-1936 (Fisher 1938) strongly suggests that the double peaks are partly at least the result of a double migration.

The distribution of the "Silver $Y$ " in Britain for the years 1933-1936 has been fully dealt with in a paper by $K$. Fisher (1938). It has been reported in all months of the year except January and February, but there are only two single captures in March (1879 and 1929); two years in which captures were recorded in April (1893 and 1903); and four years in which there were single captures in December.

The main season is therefore from May to October (Table 3). The relative abundance in the different years is shown in fig. 3. Grades 1 and 2 occurred in 35 years, of which 22 years were without records, and Grades 5 and 6 in 17 years. That is, the species was most abundant about half as frequently as it was least abundant.

\section{Catephia alchymista.}

This is extremely rare in Britain. It was first recorded in September 1858 , since when it has occurred in only six years, the maximum number in any year being 3 in 1875. In July 1894 two larvae were taken at Eastbourne. Apart from these two instances, all the records have been of single occurrences. Six of the eight adults were recorded in June, and two in September. One record comes from Cleobury Mortimer in Shropshire, one from Essex and the rest from the south coast of England. This is undoubtedly an immigrant reaching England from France. The number of records is too small to include it in the correlations.

\section{Catocala fraxini (fig. 3).}

The first record to come into this survey was that of two captures in Kent in 1827. There were a few previous records in England. The records since then are quite regular but few in any year. The highest total in any year 
was 9 in the year 1868 . After the 1827 record there was a gap of seven years before the next record in 1835 . Since then, however, the longest gap without a record was five years. The longest unbroken period of occurrences was the six years 1885 to 1890 inclusive, taking into account the occurrence of two larvae at Southport in 1886 (Table 11).

It has occurred in July, August, September and October with a maximum in September (Table 3). It arrives in Britain in late summer, and does not become established.

\section{Nycterosea obstipata (= faviata) (fig. 4).}

This insect has occurred in Britain in small numbers with frequent periods of absence. In the 75 years from 1857 to 1931 it has been unrecorded in 37 years, single specimens have occurred in 13 years, and the highest total for any year is only 23 , in 1899 . It has occurred in the months from May to November, and the months of maximum abundance are September and October (Table 3).

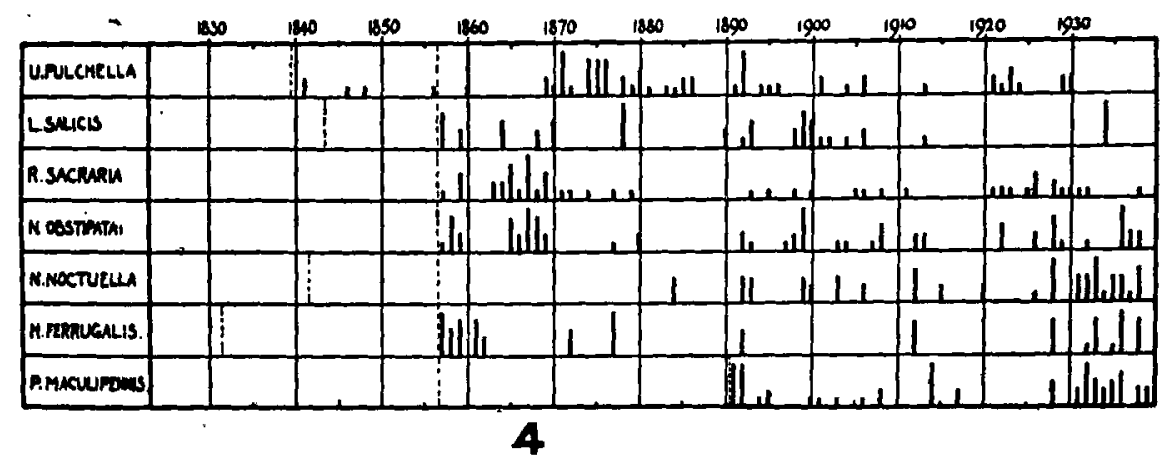

Fre. 4.-Annual abundance, in six grades, of certain British Immigrant Lepidoptera, 1824-1939.

$$
\text { Rhodometra (= Sterrha) sacraria (fig. 4). }
$$

The first record of this insect to be included was one taken in September 1857. It has occurred since then in 32 years out of 83 .

The records of monthly totals (Table 3) show that most occur in August, and that the range is from April to October.

It has occurred throughout Britain, but is recorded mainly from the southern counties of England.

\section{Utetheisa pulchella (fig. 4).}

This is a rare migrant that has appeared in Britain at intervals for periods of from one to four years.

The first record is one taken in 1840 . Since that date it has occurred in 36 years, and has been unrecorded in 64 years. The largest number reported in any year is 49 in 1892 (Table 4).

The seasonal range is from May to October, with one record for November. From Table 3 it can be seen that, although the numbers are small, there appears a definite peak in April and May, and another in September and October.

In Britain it has occurred mainly in the South of England, but has been taken as far north as Aberdeen. Blair (1925, Entomologist 58 : 5) has suggested that it might be resident in the Scilly Islands. 


\section{Leucoma salicis (fig. 4).}

This insect is a resident in Britain but is reinforced at times by immigration. In June 1878, at Harwich, "thousands appeared . . . having crossed the sea. They resembled a fall of snow." At Salzburg, Germany, on 22nd August 1886, "millions were flying from N.E. to S.E. (sic) between 2 and 4 p.m."

Towards the end of August 1900, large numbers were observed about 10 miles off Flushing at about $5 \mathrm{a} . \mathrm{m}$. All were flying to the north-west.

In early July 1929, an immigration was recorded at Southwold, Suffolk.

The occurrences of the moth are shown graphically in fig. 4. The maximum abundances occurred in 1878 and 1934.

It occurs as adults mainly in June, July and August, but in 1908 and 1912 single specimens were recorded in September and in 1933 one occurred in October.

\section{Nomophila noctuella (fig. 4).}

This species, although now recognised as a regular migrant, was not well recorded before 1931. Since then, however, very full reports have been collected. It has been noted particularly when it has occurred in abundance with $P$. gamma and $V$. cardui. It has occurred in all months except January, February, April and December, but only once in March, once in November and three times in October, so that the main period of occurrence is May to September, with a peak in August and September (Table 3).

It is fairly widespread in Britain. The only record of a definite flight direction was on 20th March 1935, at Round Island Lighthouse, Scilly Islands, when 6 or 7 were seen flying to the north.

\section{Hapalia ferrugalis (fig. 4).}

This is a migrant which is recorded in only 18 years between 1857 and 1931. Of these, single specimens have been recorded in 8 years. The highest totals occurred during the years 1857, 1877 and 1936, each with over 200 insects (Table 4).

It has occurred from May to November, with the peak months August and September (Table 3). It has been recorded mainly from the southern counties of England, but also in Scotland, the North of England and in Ireland. In August 1898 and in September 1930, numbers were taken at sea in the Mediterranean.

\section{Plutella maculipennis (fig. 4).}

This insect, "The Diamond-Back Moth," causes extensive damage at times to the crucifer crops in Britain. It has occurred sporadically in great swarms mainly along the east coast of Britain, from the Shetlands to Kent.

The records begin as late as 1891. Since then, it has been reported in 22 years. It is quite likely that, as it is not conspicuous, it becomes recorded only when it occurs in great abundance.

The records were almost entirely descriptive, those since 1931 have been in greater detail than those previous. It appears to occur from May to October, and most frequently in June and August. It has not been included in the correlations. 
J. A. Downes on studies in the migration of Lepidoptera.

IV. LEPIDOPTERA OBSERVED AT LIGHTSHIPS OFF THE SOUTH AND EAST COASTS of Exgland, 1932-1939.

By M. E. Grbis.

The material available consists of records of Lepidoptera appearing at ten light vessels off the south and east coasts of England. Through the activities of

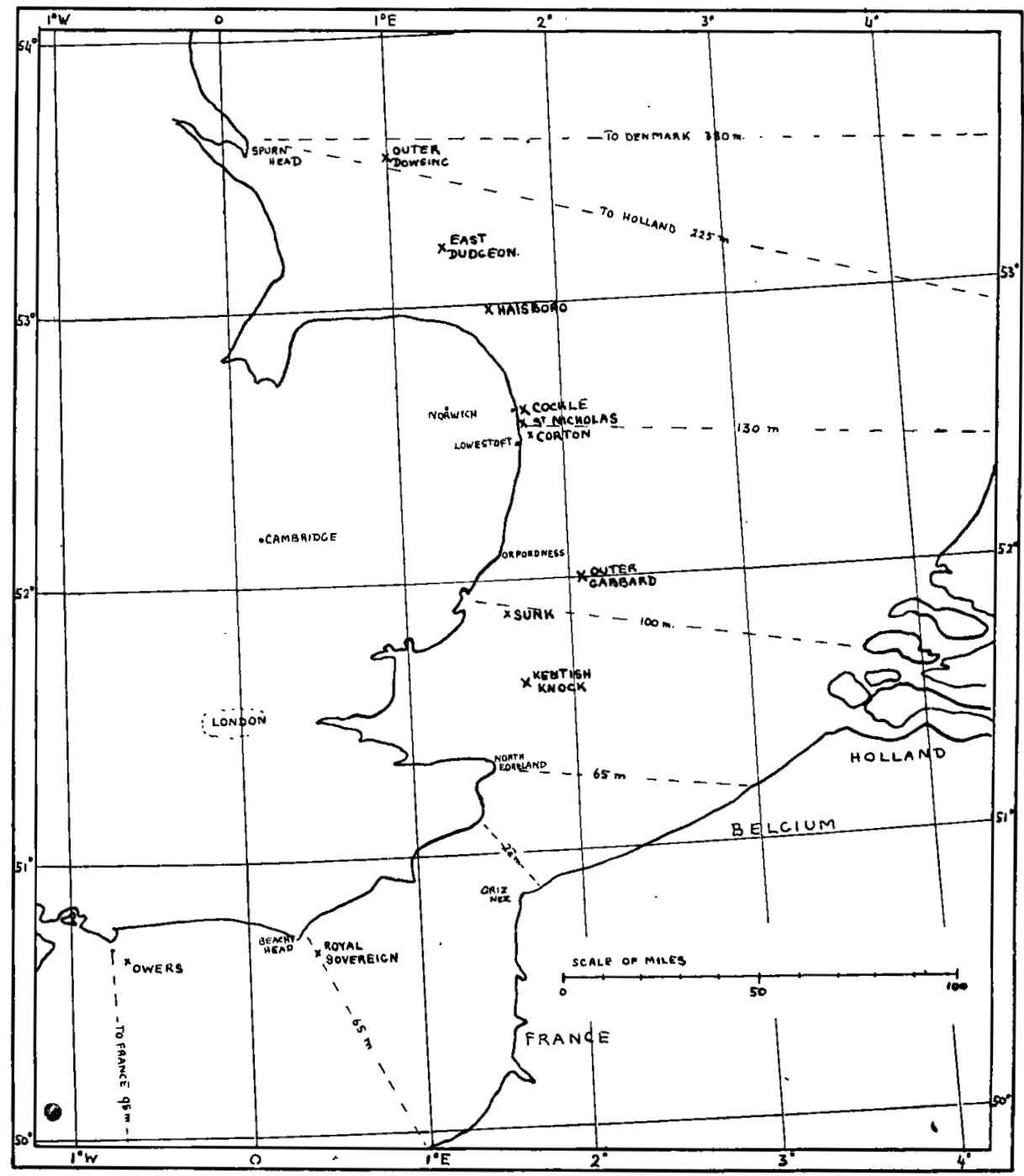

5

FIG. 5.-Map showing the position of the lightships from which records were received.

the Insect Immigration Committee of the South-Eastern Union of Scientific Societies about three hundred and ninety records have been sent in by various TRANS. R. ENT. SOC. LOND. 92. PART 1. (JULY 1942.) 
lightship keepers during the seven years 1932-1939, and these were passed on to Rothamsted for study.

The names and positions of the lightships are shown in the map (fig. 5) and in Table 10. The latter gives also the distance from the nearest land and the name of the observers. Our thanks are due to all those voluntary assistants, and to the officials of Trinity House who gave permission for their co-operation.

Naturally records collected in this way are fragmentary; only a few of the lightships assisted, and often some of our best observers were transferred to other localities. Therefore, the number of observations at any lightship

TABLE 10.

List of lightships with their positions and the names of observers who sent in records.

\begin{tabular}{|c|c|c|c|}
\hline Name & $\begin{array}{c}\text { Con- } \\
\text { traction }\end{array}$ & Position & Observers \\
\hline $\begin{array}{l}\text { 1. Outer Dowsing. } \\
\text { 2. East Dudgeon. } \\
\text { 3. Outer Gabbard. } \\
\text { 4. Haisboro'. } \\
\text { 5. Sunk. } \\
\text { 6. Royal Sovereign. } \\
\text { 7. Owers. } \\
\text { 8. Corton. } \\
\text { 9. Cockle. } \\
\text { 10. St. Nicholas. }\end{array}$ & $\begin{array}{l}\text { OG. } \\
\text { H. } \\
\text { S. } \\
\text { R.S. } \\
\text { o. } \\
\text { Cn. } \\
\text { Ce. } \\
\text { St. N. }\end{array}$ & $\begin{array}{l}30 \mathrm{~m} . \text { E. of Spurn Head, S. Yorks. } \\
22 \mathrm{~m} \text {. N.E. of Blakeney Pt., N. Norfolk. } \\
20 \mathrm{~m} \text {. E.S.E. of Orfordness, S. Suffolk. } \\
11 \mathrm{~m} \text {. E.N.E. of Cromer, Norfolk. } \\
9 \mathrm{~m} \text {. N.E. of Mundesley, Norfolk. } \\
10 \mathrm{~m} \text {. S.E. of Felixstowe, S. Suffolk. } \\
7 \mathrm{~m} . \text { S.E. of Eastbourne, Sussex. } \\
7 \mathrm{~m} \text {. off Selsea Bill, W. Sussex. } \\
3 \frac{1}{2} \mathrm{~m} . \text { N.E. of Lowestoft, N. Suffolk. } \\
2 \mathrm{~m} \text {. E.N.E. of Yarmouth, Norfolk. } \\
1 \mathrm{~m} \text {. off Gorleston, S. Norfolk. }\end{array}$ & $\begin{array}{l}\text { J. W. R. Reeve. } \\
\text { H. Maylett. } \\
\text { S. G. Sharman. } \\
\text { J. Audley. } \\
\text { W. F. Fuller. } \\
\text { C. L. R. Turnor. } \\
\text { W. F. Willgress. } \\
\text { F. England. } \\
\text { C. L. R. Turnor. } \\
\text { F. J. Morgan. } \\
\text { S. G. Rowe. } \\
\text { W. F. Willgress. } \\
\text { H. G. Hollis. } \\
\text { S. G. Sharman. } \\
\text { E. Bulley. } \\
\text { W. F. Willgress. } \\
\text { S. G. Sharman. }\end{array}$ \\
\hline
\end{tabular}

cannot be taken as a measure of the comparative frequence of flights in that neighbourhood. However, the positive evidence obtained, always holds good, and much of its value lies in the possibility of correlation with records on land.

In most cases specimens have been sent in with the observations; whenever identification was doubtful the records have not been used. A source of inaccuracy more difficult to correct is that associated with the estimation of the numbers of insects present in a flight : for example, the term " several " has a wide scale of values and may easily vary in its meaning from one observer to another. Data concerning the direction of movement and that relating to the weather conditions are probably unusually accurate as such things help to make up the daily routine of the lightship keepers.

Altogether about 120 species of Lepidoptera have been recorded by the observers. Of these the majority only occurred on very few occasions and their presence may have been accidental. Table 11 shows 85 species which occurred only singly or on not more than three occasions. Of these only 7 (or 1 in 12) were previously considered as, or suspected to be, migrants; these are marked with an asterisk in the table. The others may be considered as possible migrants but a final decision must await further evidence. 


\section{TabLe 11.}

List of Lepidoptera which were recorded on not more than three occasions at the lightships. * denotes previously considered as, or suspected to be, a migrant.

Rhopalocera.

* Nymphalis antiopa
*Pieris napi
Pararge megera
Maniola jurtina .
Lycaena phlaeas
Lycaenopsis argiolus
Polyommatus icarus

Sphingidat.

* Acherontia atropos

* Macroglossum stellatarum

* Herse convolvuli

Lathoe populi

Mimas tiliae

Bombyces.

Leucodonta bicoloria Lophopteryx capucina Asphalia dilutata .

* Leucoma salicis Malacosoma neustria Lasiocampa quercus Philudoria potatoria Gastropacha quercifolia Cilix glaucata Spilosoma lubricipeda Spilosoma lutea Eilema lurideola

\section{Noctuldae.}

Apatele rumicis Agrotis exclamationis

Euxoa nigricans
Euxoa tritici
Amathes xanthographa
Diarsia rubi
Triphaena comes
Triphaena orbona
Mamestra brassicae
Hadena trifolii
Hadena bicruris :
Apamea sordens :
Apamea secalis :
Procus strigilis
Actinotia polydon
Aporophyla australis
Nonagra typhae
Nonagra dissoluta
Arenostola pygmina
Arenostola phragmitidis
Leucanea pallens .
Leucanea impura
Meristes trigrammica
* Laphygma exigua
Petilampa minima?
Amphipyra tragopoganis

Euxoa nigricans Diarsia rubi Triphaena comes Hadena trifolii Hadena bicruris Procus strigilis Actinotia polydon Aporophyla anstralis Nonagra dissoluta Arenostola pygmina Leucanea pallens . Leucanea impura. * Laphygma exigua Amphipyra tragopoganis
H. 1936 Aug. 26 . Cn. 1934 Aug. 21. Cn. 1935 Aug. 10; 1935 Aug. 22. OD. 1933 Aug. 20.

RS. 1933 July 1.

RS. 1933 Aug. 29.

Cn. 1935 Aug. 10. Cn. 1934 Aug. 16.

OD. 1937 Sept. $23 . \quad$ St. N. 1932 Sept. 18. S. 1938 Sept. $25 . \quad$ Cn. 1934 July 6. ED. 1932 Aug. 30. OG. 1939 Aug. 15. Cn. 1935 July 1.

Ce. 1935 June 30.

S. 1938 Aug. 24.

H. 1934 Sept. 10.

Cn. 1934 Nov. 21.

OG. 1939 Aug. 1.

S. 1938 Aug. 10.

Ce. 1935 July 27.

S. 1938 July 19.

St. N. 1938 July 29.

OD. 1935 Aug. 12

OG. 1939 July 11 .

RS. 1933 July 12.

Cn. 1935 Aug. 10.

Ce. 1935 July 16.

OD. 1935 Oct. 3. OG. 1939 July 8. Cn. 1935 July 1.

St. N. 1938 Sept. 24.

OD. 1935 Aug. 24. Cn. 1935 Aug. 31.

OD. 1935 Sept. 5. Cn. 1935 July 23.

S. 1939 June 11.

OD. 1935 July 6. S. 1938 Aug. 18.

S. 1938 July 25.

RS. 1934 July 23.

St. N. 1938 June 21.

RS. 1933 Aug. 7. St. N. 1938 Sept. 27.

Cn. 1935, July 10.

OG. 1939 July 29.

RS. 1939 Aug. 19.

St. N. 1938 Aug. 23.

H. 1934 Aug. 19.

H. 1934 Aug. 6.

H. 1935 Aug. 12.

St. N. 1938 Aug. 29.

OD. 1935 July 23.

OG. 1939 July 11.

St. N. 1938 Aug. 24.

St. N. 1937 June 16.

S. 1938 Sept. 26.

RS. 1939 Âug. 23.

OD. 1933 Aug. 25. S. 1938 Aug. 5. 
Noctuidae.

Cosmia trapenzina

Agrochola pistacina

Cucullia asteris

Scoliopteryx libatrix

Geometridat.

Comibeana pustulata

Sterrha aversata.

Scopula imitaria.

Operophtera brumata

Lygris prunata

Lygris populata

Ephyia bilineata.

Eupithecia centaureata

Cabera exanthemata

Deuteronomos alniaria

Selenia bilunaria.

Crocalis elinguaria

Ourapteryx sambucaria

Lycia hirtaria

Cleora repandata:

Lithina chlorosata

Chiasmia clathrata

Hepialidae.

Hepialus humuli .

Pyralidae.

Loxostege verticalis

Hydrocampa sp.

Pyralis glaucinalis

Crambidae.

Crambus sellasellus

Crambus sp.

Tortrictoan.

Tortrix forsterana

Tortrix viridana

Tortrix sp.

Cydia (Carpocapsa) pomonella

Argyroploce salicella

Argyroploce striana

Tineidae.

Borkhausenia pseudospretella . Tinea sp.

Phthorimea instabillella
OG. 1939 July 7. S. 1937 Aug. 5; 1938 Aug. 11.

St. N. 1935 Oct. 1.

RS. 1939 Aug. 16.

S. 1937 Oct. 29.

O. 1932 July 10

OD. 1934 July 18.

OD. 1934 July 17.

S. 1937 Nov. 24; 1938 Nov. 23; 1938 Dec. 12.

OG. 1939 July 13.

OD. 1934 July 23.

OD. 1935 July 13.

S. 1937 Aug. 6; 1937 Aug. 7; 1938 Sept. 6.

O. 1932 July 10.

OD. 1933 Aug. 15. Ce. 1935 Sept. 7. St. N. 1935 Sept. 26.

S. 1939 April 12.

H. 1934 Aug. 21. RS. 1934 July 22.

. S. 1938 June 24; 1938 July 22. O. 1932 July 13.

H. 1934 May 12.

- St. N. 1937 July 2.

- ED. 1933 May 29.

- OD. 1933 July 18.

Cn. 1935 July 10.

- OD. 1934 July 18; 1934 Aug. 4. S. 1938 Aug. 27.

OD. 1935 Aug. 12.

OD. 1934 July 18; 1935 Aug. 17; 1935 Aug. 19.

OD. 1935 Aug. 19.

OD. 1935 July 19. ED. 1933 June 17. OG. 1939 July 13. Cn. 1935 Aug. 3.

OD. 1935 July 19.

S. 1938 June 18; 1938 June 19. O. 1932 July.

OG. 1939 July 19.

OD. 1935 Aug. 17

- OD. 1934 July 18.

- Cn. 1935 July 13.

OD. 1935 July 20.

- OD. 1934 July 18.

- Cn. 1935 July 5.

Table 12 shows the 35 species which have occurred on more than three occasions or in considerable numbers on one or two days. Of these 13, or more than 1 in 3, were known or suspected migrants. The species are arranged in order of frequency of occurrence and the lightships in order of distance from land. It will be seen that 6 out of the 8 most frequently occurring species were known to be migrants; and that only 4 out of the 35 species did not occur in the first three light vessels, which are 20 miles or more from land. 


\begin{tabular}{|c|c|c|c|c|c|c|c|c|}
\hline 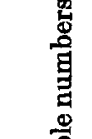 & 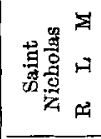 & $\mid \begin{array}{llll}1 & 1 & 1 & 1 \\
1 & 1 & 1 & 1 \\
01 & 1 & 1\end{array}$ & $\left|\begin{array}{l|lll}-1 & 1 & 1 & 1 \\
-1 & 1 & 1 & 1 \\
- & -\infty & 0 & 1\end{array}\right|$ & $\begin{array}{lllll}1 & 1 & 1 & 1 & 1 \\
1 & 1 & 1 & 1 & 1 \\
\mid & -1 & 1 & 1 & 1\end{array}$ & \begin{tabular}{rll|ll}
1 & 1 & 1 & 1 & 1 \\
1 & 1 & 1 & 1 & 1 \\
-1 & 1 & 1 & 1
\end{tabular} & 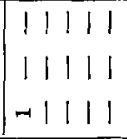 & $\begin{array}{llllll}1 & 1 & 1 & 1 & 1 \\
1 & 1 & 1 & 1 & 1 \\
1 & 1 & 1 & 1 & 1 \\
\end{array}$ & $\begin{array}{lllll}1 & 1 & 1 & 1 & 1 \\
1 & 1 & 1 & 1 & 1 \\
1 & 1 & 1 & 1 & 1 \\
\end{array}$ \\
\hline & & 11111 & 11111 & 11111 & 111111 & 11111 & 11111 & 11 \\
\hline & & 11111 & 11111 & 11111 & 11111 & 11111 & 11111 & 11,111 \\
\hline & & 11110 & $|--1| \mid$ & 11111 & 11111 & 1111 & 111111 & 11111 \\
\hline & & $|-1|||$ & $|\sim|||$ & 11111 & 11111 & 11 & 11111 & 11111 \\
\hline & H & 11111 & -1111 & 11111 & 11111 & 11111 & -1111 & 11111 \\
\hline & & andant & $|\neg \pi| r|r|$ & 111111 & 11111 & $\mid 10001$ & $|\pi-1| \mid$ & 11111 \\
\hline & & $|-|-\mid$ & $\infty 1111$ & 111111 & 11111 & 11 & 11111 & 11 \\
\hline & & 11111 & 11111 & 11111 & 11111 & 11111 & 111111 & 11111 \\
\hline 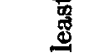 & & trasens & $|+n|-1 \mid$ & - $\operatorname{|rar} \mid 1$ & $11+11$ & $|1-1| \mid$ & 1111111 & 11111 \\
\hline & & 11111 & 11111 & 11111 & 11111 & 11 & 11111 & 11111 \\
\hline & & 11111 & -1|| $\mid$ & 11111 & 11111 & 11 & 11111 & 11 \\
\hline & & 11 मतल & $1-1111$ & $|-| \otimes \mid-1$ & $|1-1|$ & $1-1$ & 111111 & 11 \\
\hline & & - $\mid$ | on $\mid$ & 1||$न-1$ & 11111 & 11111 & 1 & 1111 & 11 \\
\hline & 悬 & $|-| a|| \mid$ & ||$|-1|$ & 111111 & $1111=$ & $|-1||-1|$ & ||$-1 \mid$ & $|A-1|||$ \\
\hline 5 & & $\left|m+g^{\infty}\right|$ & $\rightarrow \infty$ & $|+n|||$ & $\infty 1$ तnt & $r$ & 11 & an \\
\hline$F$ & & $|-1| 1$ & 11111 & 11 & 11 & & 11 & 11 \\
\hline 。 & 惫 & $\mid \begin{array}{llll}-1 & 1 & 1 & 1\end{array}$ & 11111 & & 11 & & 11 & \\
\hline$\overline{9}$ & & 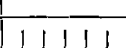 & 111 & & & & & \\
\hline & & $|\sim||-1|$ & $|\pi \infty| \pi$ & 11111 & 111111 & ||$-1 \mid$ & $11111-1$ & \\
\hline & & $|-+| \infty \mid$ & $|\pi \infty| \mid-$ & $\sin |1|$ & $|\approx|||$ & $|1-1| 0$ & 11110 & 11111 \\
\hline & & 11111 & & 11 & 11111 & 11111 & 11111 & 11111 \\
\hline & & $|-1| \pi$ & $\infty||-\mid$ & $|1-| \mid$ & 11111 & 11111 & $|-|-|-|$ & 11111 \\
\hline & & $\rightarrow \infty 10 \infty$ & $=11=1$ & In & 11111 & 11 & $|-| \theta \mid$ & 11111 \\
\hline & 㫮 & 1111 & 1111 & 11 & 11111 & 1 & 11 & 11 \\
\hline 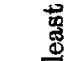 & 岁巻 & -1111 & $|-111|$ & $|-||\cos |$ & 11111 & 11 & 11111 & 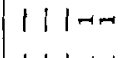 \\
\hline & & & & & & & & \\
\hline 7 & 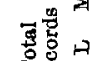 & $\infty$ & $A-$ & $4 \infty 1$ & $1 \pi$ & - & $\mid \begin{array}{l}-\pi a m a n \\
11\end{array}$ & | \\
\hline & & $\mid$ & $\because=12 \pi \infty \pi^{\infty}$ & armonas & 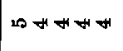 & 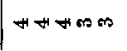 & mancint & 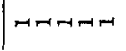 \\
\hline 要 & & 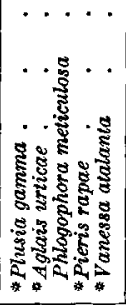 & 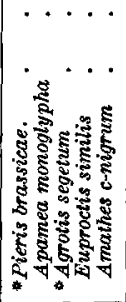 & 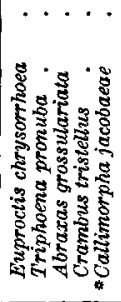 & 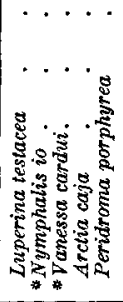 & 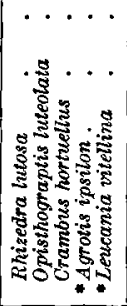 & 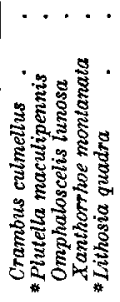 & 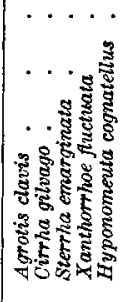 \\
\hline
\end{tabular}




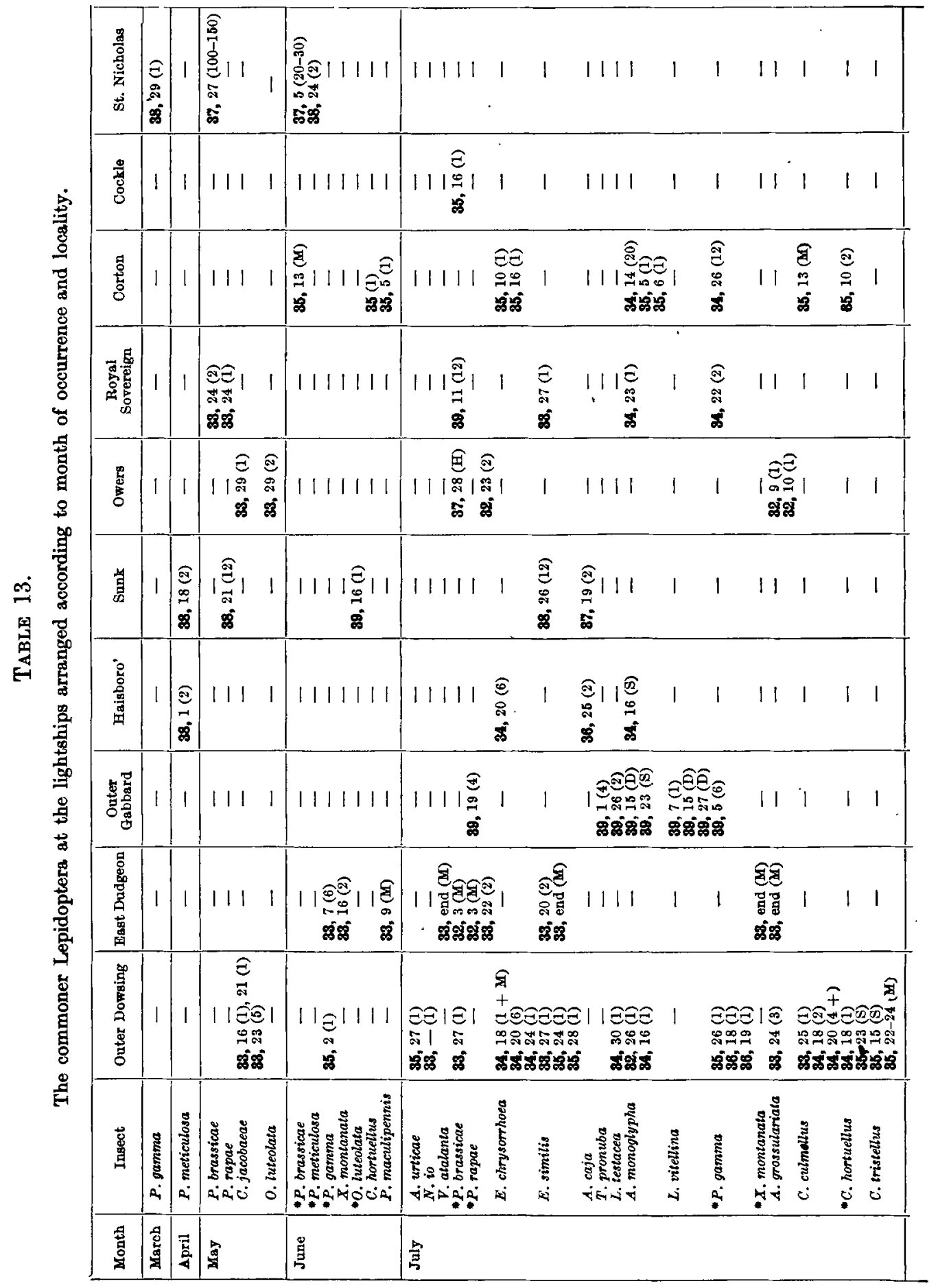




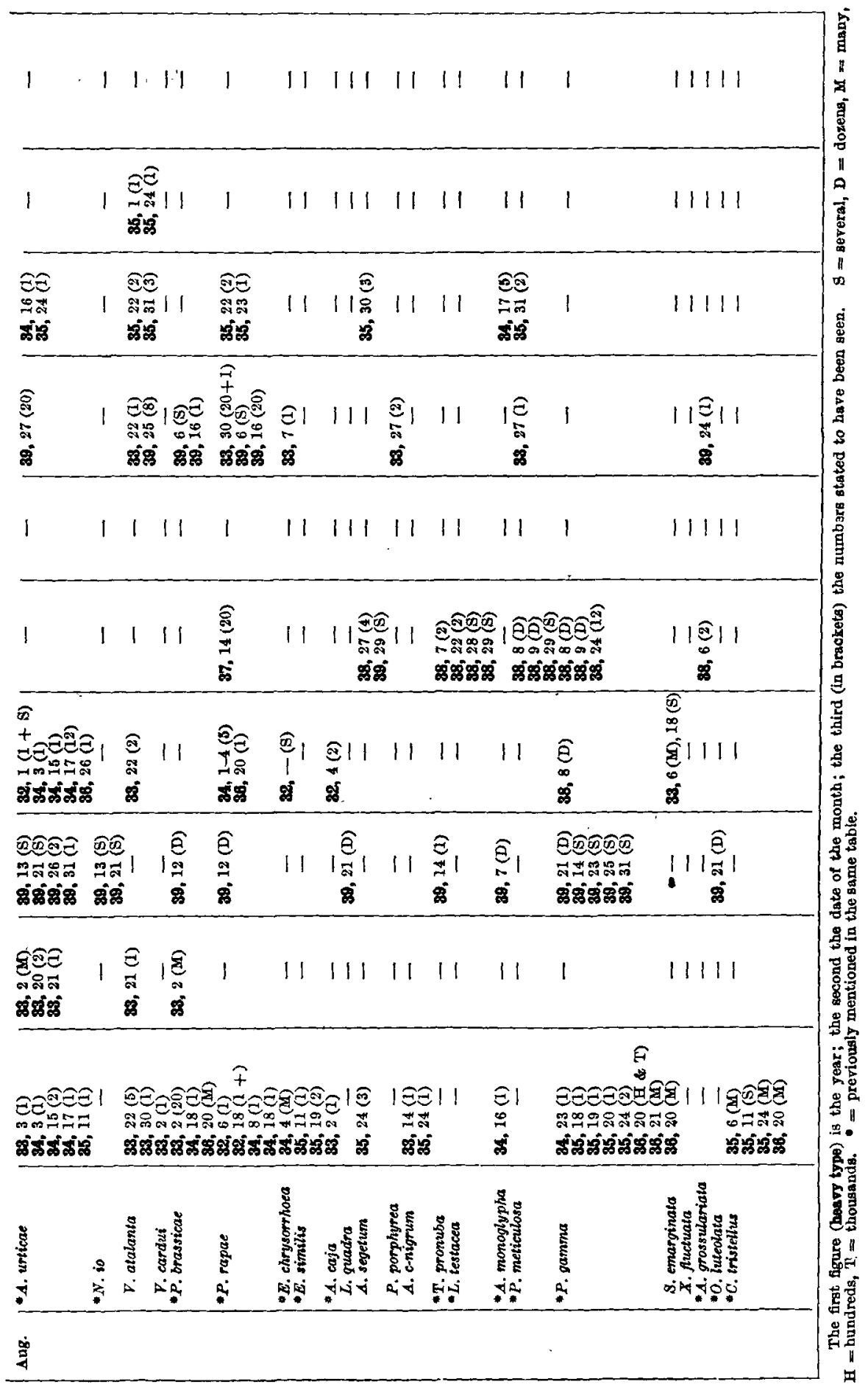




\begin{tabular}{|c|c|c|c|c|}
\hline 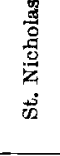 & 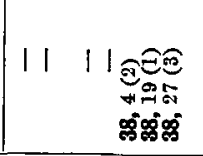 & 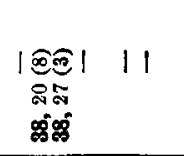 & 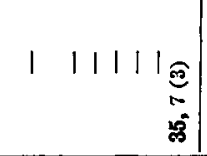 & 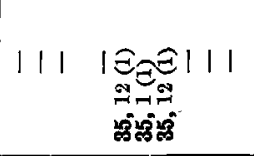 \\
\hline 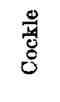 & 11111 & 111111 & 111111 & 11111111111 \\
\hline 密 & 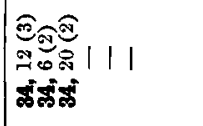 & 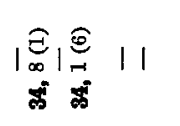 & 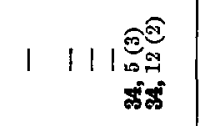 & 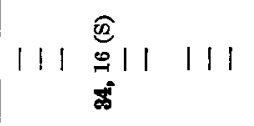 \\
\hline 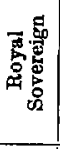 & 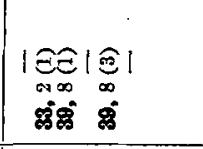 & 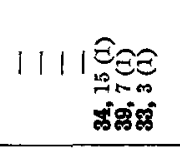 & 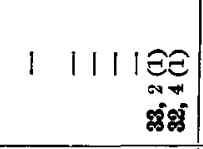 & 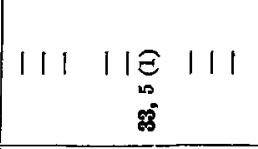 \\
\hline 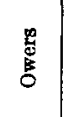 & 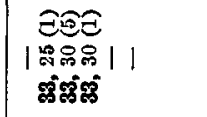 & 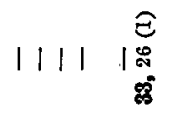 & 111111 & 1111111111 \\
\hline 喜 & 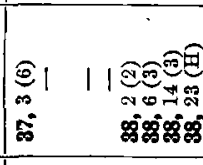 & 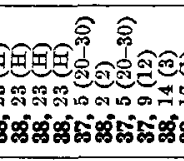 & 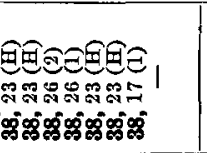 & 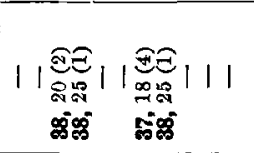 \\
\hline 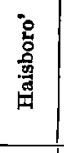 & 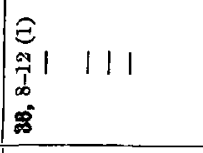 & 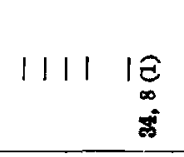 & 1.11111 & $\begin{array}{lllll}11 & 11 & 1 & 11\end{array}$ \\
\hline 焉 & 11111 & 111111 & 111111 & 11111111111 \\
\hline 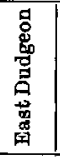 & 111111 & 111111 & 111111 & 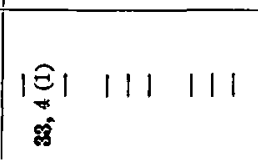 \\
\hline 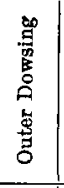 & $\mid \begin{array}{lll}E^{1} & 111 \\
6 & 11 \\
5 & & \\
0 & & \end{array}$ & 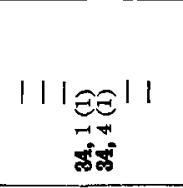 & 111111 & 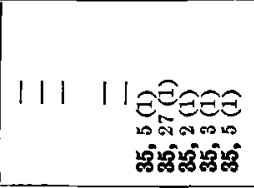 \\
\hline $\begin{array}{l}\overrightarrow{\mathbf{D}^{\circ}} \\
\text { 晋 }\end{array}$ & 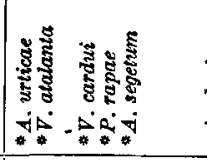 & 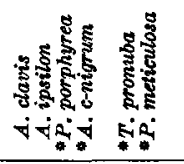 & 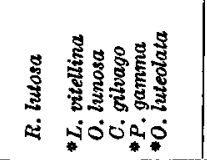 & 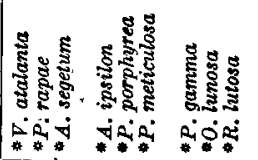 \\
\hline 善 & 蒡 & & & $\dot{8}$ \\
\hline
\end{tabular}


On the whole the species in this table must be considered as likely to be regular migrants, and this applies particularly to the noctuids $P$. meticulosa (see also p. 141) and $A$. monoglypha, both of which occurred on more than ten occasions.

One of the most unexpected species to be high up in the list is the geometrid moth Abraxas grossulariata, which occurred on seven occasions. On only one of these was any number present, but three records were over 20 miles from land. We are not aware that there had been any previous suggestion of migration in this insect.

It is interesting to note that of the six butterflies included in Table 12 all were previously known as migrants. The new suspected species are all moths about which our knowledge of possible movements is at a much lower level.
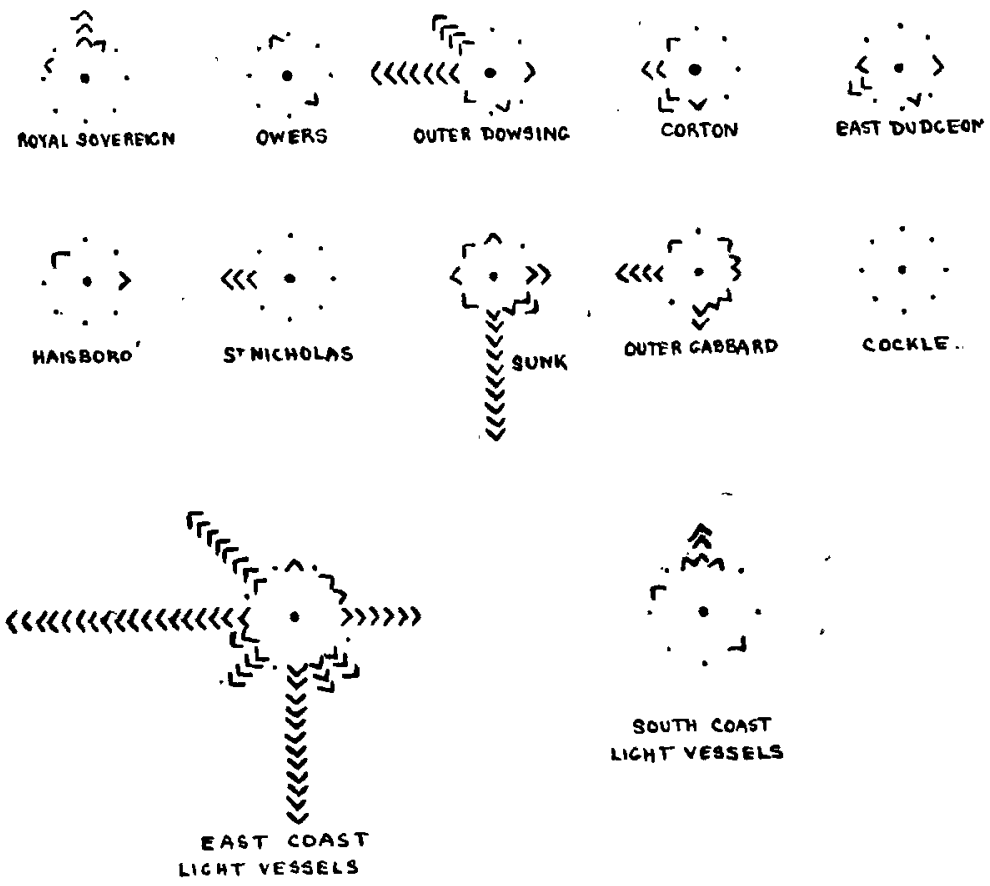

$$
\text { LICHT VESSELS }
$$

Fra. 6.-Compass direction of the flights observed at the different lightships.

North at the top of the page.

Table 13 shows the more common migrants listed according to their seasonal distribution, with the lightships at which they were reported. There are 9 occurrences of 4 species in May, and 10 of 8 species in June. In July activity increases rapidly with 61 records of 18 species, and reaches its maximum in August with 109 records of 23 species. In September activity falls off to 48 records of 17 species and again in October to 17 records of 9 species.

Finally Table 14 shows further details of the larger flights arranged under the species concerned, with the time of day, numbers present, wind direction and notes.

Altogether there are 88 records of occurrences of more than five insects at a time, on which either the direction of flight, or the direction of wind, or both, was given by the observer. These have been analysed in figs. 6,7 and 8 .

Fig. 6 shows the compass directions of the flights recorded at each of the 


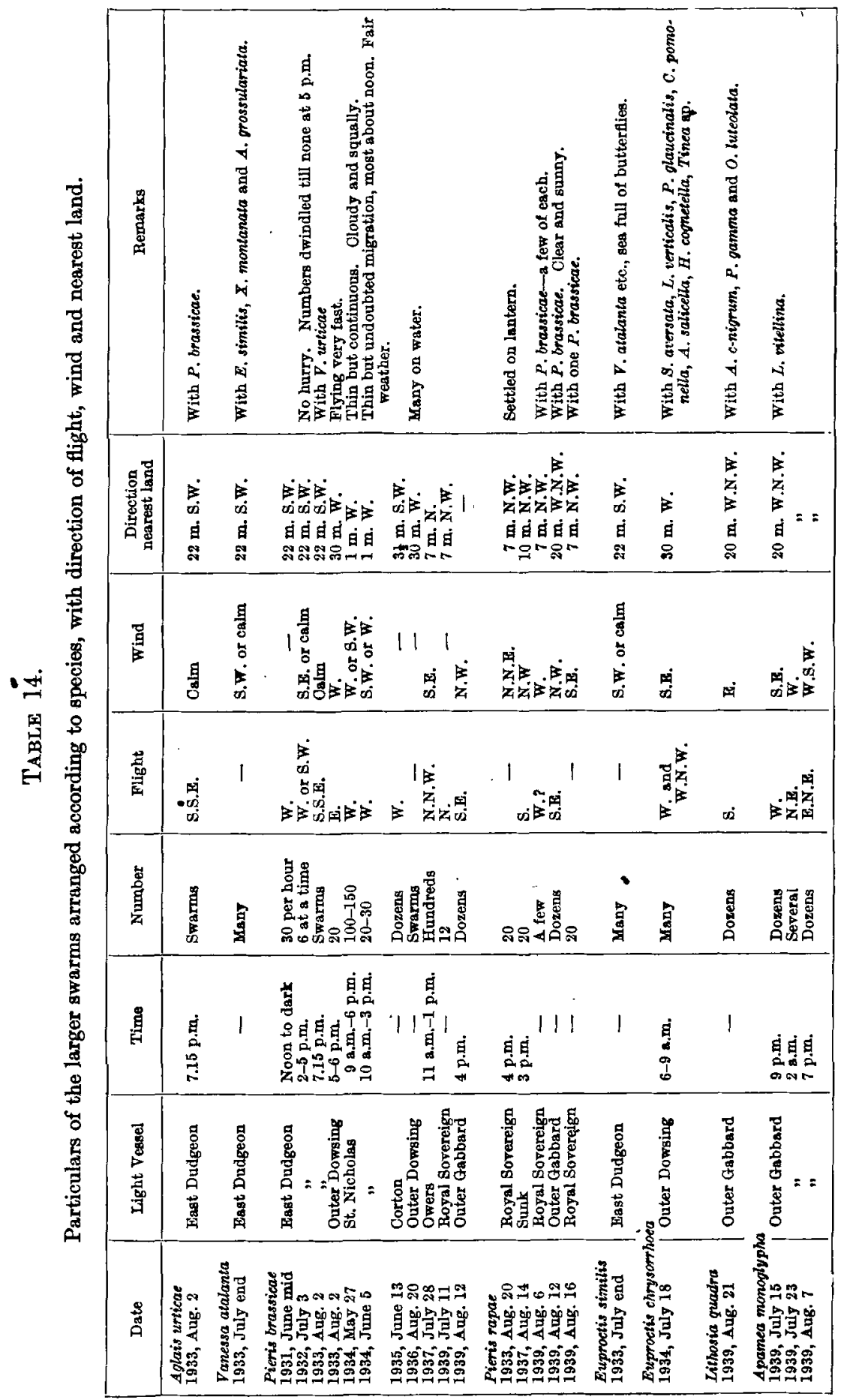


J. A. Downes on studies in the migration of Lepidoptera.

\begin{tabular}{|c|c|c|c|c|c|c|c|c|c|c|c|c|c|}
\hline & $\begin{array}{r}r \\
\\
\end{array}$ & 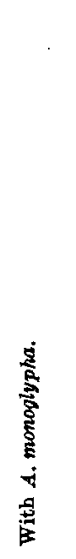 & & 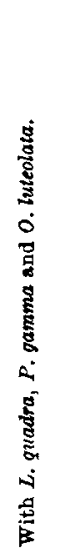 & 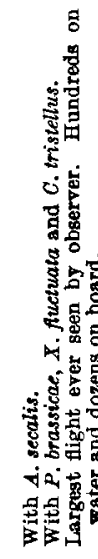 & & 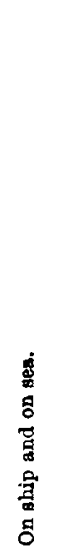 & 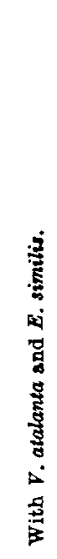 & 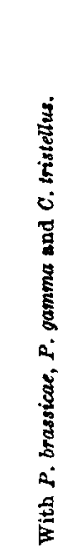 & 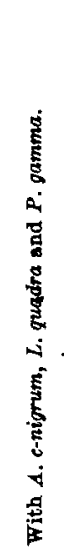 & & 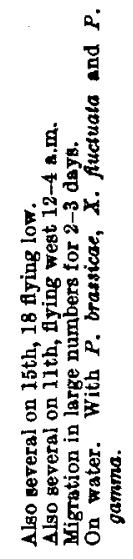 & 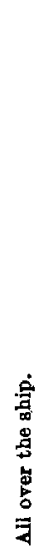 \\
\hline 递 & $\begin{array}{l}\dot{8} \\
\dot{z} \\
\dot{g} \\
\dot{1}\end{array}$ & 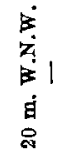 & 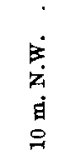 & 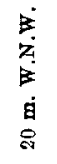 & 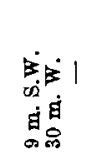 & & $\begin{array}{l}\dot{B} \\
\dot{a} \\
\dot{g} \\
\dot{a}\end{array}$ & 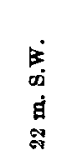 & $\begin{array}{l}\dot{8} \\
\text { 昌 } \\
\text { 品 }\end{array}$ & 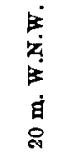 & $\begin{array}{l}B \\
\infty \\
\dot{a} \\
\dot{m}\end{array}$ & $\begin{array}{l}\dot{8} \\
\text { 自: = }\end{array}$ & $\begin{array}{l}\dot{B} \\
\dot{0} \\
\mathbb{a}\end{array}$ \\
\hline$\tilde{z}$ & 安安安 & ल9 & 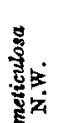 & $\dot{x}$ & 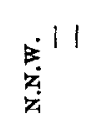 & Pi & 里 & 영 & 1 & $\mathbf{x}^{\circ}$ & $\dot{x}$ & $\begin{array}{l}1 \\
\frac{1}{8 x} \\
8 x_{i}\end{array}$ & 1 \\
\hline 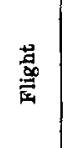 & 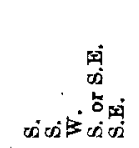 & 1 & 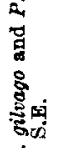 & $\dot{\omega} \dot{A}$ & & $\ddot{D}$ & $!$ & $\begin{array}{l}\$ \\
8\end{array}$ & $\begin{array}{l}8 \\
8 \\
8\end{array}$ & $\omega^{*}$ & 1 & 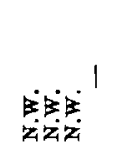 & 1 \\
\hline 岁 & 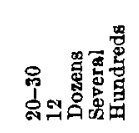 & 善善 & 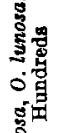 & 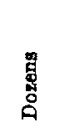 & 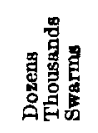 & & 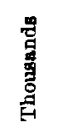 & 塄 & 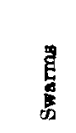 & 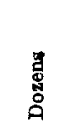 & 总 & 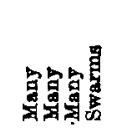 & 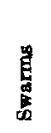 \\
\hline 其， & 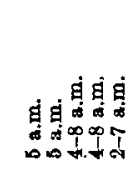 & $\underset{\infty}{\dot{g}}$ & 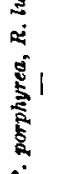 & 1 & 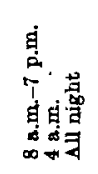 & & 1 & $y^{1}$ & 1 & 1 & 1 & | & 造 \\
\hline 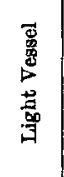 & 意 $=:=$ & 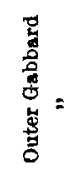 & 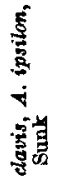 & 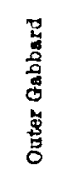 & 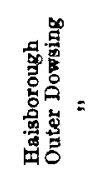 & 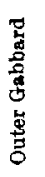 & 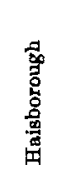 & 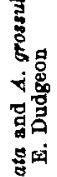 & 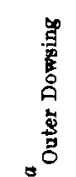 & 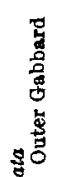 & 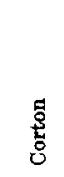 & 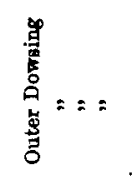 & 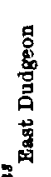 \\
\hline 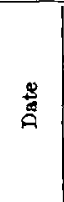 & 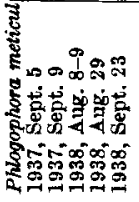 & 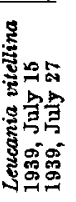 & 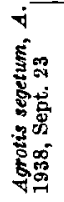 & 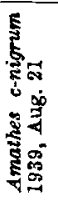 & 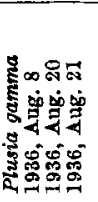 & $\dot{\theta}$ & 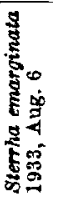 & 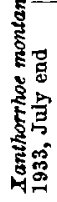 & 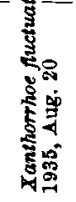 & 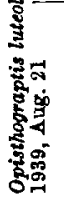 & 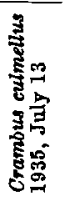 & 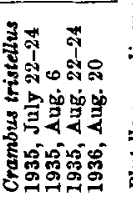 & 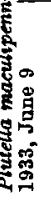 \\
\hline
\end{tabular}


ten lightships and also a general summary for those off the east coast and those off the south coast. The former records are predominantly to north, northwest and south (see below). The latter are very few in number and chiefly towards the north.
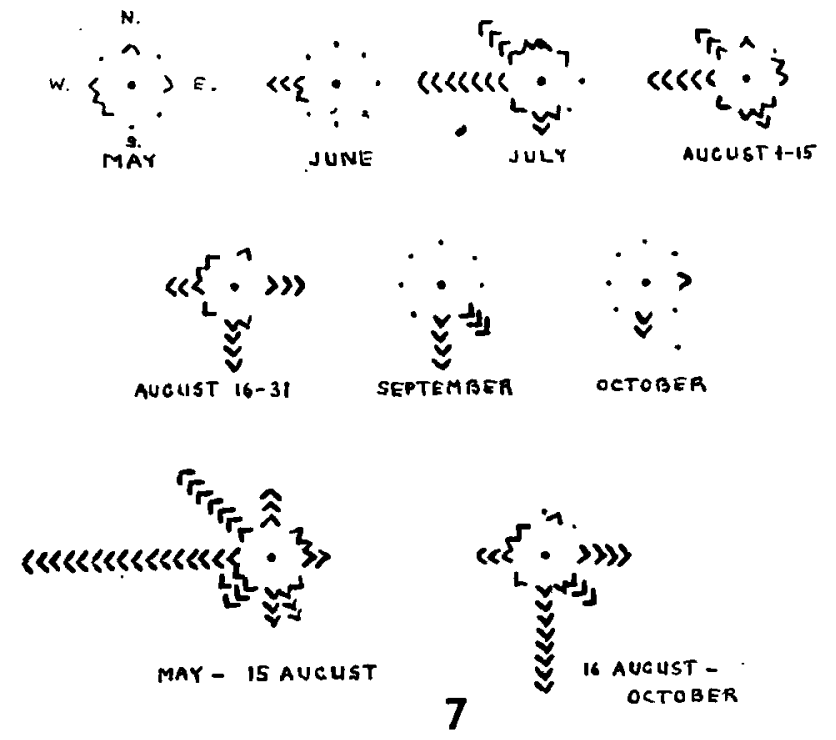

Fra. 7.-Directions of flights observed at the different lightships according to the month of occurrence.

Fig. 7 shows the same records analysed according to month. They range from May to October, with a maximum of 31 flights in August. It was decided to,divide August into two periods as there appeared to be a change in direction of flights during this month. The summaries from May to mid-August

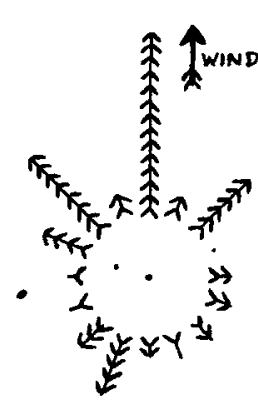

A

FLICHT AND WIND

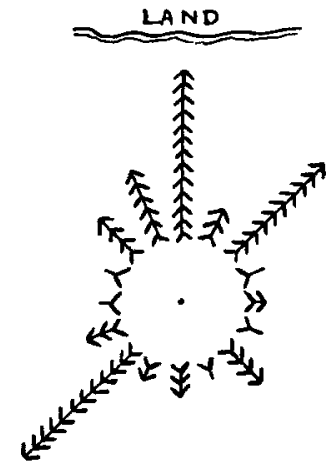

B

FLIGHTAND LAND

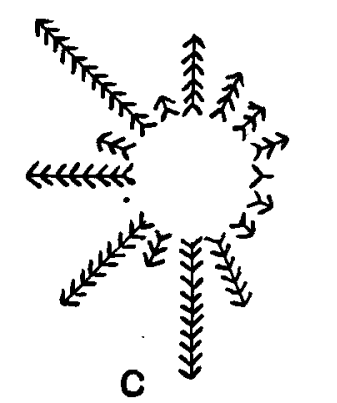

WINO AND LAND

Fra. 8.-Direction of flights observed at lightships in relation to wind and land :-A. Angle between flight and wind; B. Angle between flight and nearest land; C. Angle between wind and land at time of flight. 
and from mid-August to October show a quite definite change of direction from predominantly west and north-west in the first period to towards the south, south-east and east in the second.

Fig. 8 shows an analysis of the same flights in relation to the direction of the wind, and the nearest land. Fig. 8, A, indicates that there have been distinctly more records of flights with the 'wind than against it. Fig. 8, $\mathbf{B}$, seems to suggest a slight preference for the insects to fly towards the land, but the preponderance is not definite. Fig. 8 , c, indicates that the flights are not more frequently recorded with a wind on or off shore. The apparent asymmetry of this figure is probably due to the presence of prevailing winds in one direction along the shore.

\section{Previous records at British light vessels.}

W. Eagle Clark, a great student of the migration of birds, made some observations on the presence of insects at light vessels.

In 1901 on Eddystone Lighthouse, situated 10 miles south-south-west of Rame Head near Plymouth, he recorded as follows (1904, Ent. mon. Mag. $40: 9-10):-$

" 23rd September, Agrotis segetum (1).

" 1st October; 10 p.m. to 2 a.m. (on 2nd); Many hundreds of moths, of which captured specimens included $A$. ypsilon, $A$. segetum and $H$. meticulosa. Wind west light to calm.

" 12 th October; Moths present in great numbers including $H$. meticulosa, $A$. ypsilon, $A$. segetum and $\bar{P}$. gamma.

"6th November; H. meticulosa."

He adds: " $H$. meticulosa appears to be the greatest traveller, it was not only the most abundant species observed but also the most frequent visitor."

Again in 1903 on the Kentish-Knock light vessel, which is in the mouth of the Thames 21 miles north-east of Margate, Kent, and 21 miles south-west of the Naze, Essex (see fig. 5), he records (1903, Ent. mon. Mag. 39 : 289) numbers of $V$. cardui and $P$. gamma from $8.45 \mathrm{p} . \mathrm{m}$. to midnight on the night of 22nd September. On the 28th September specimens of $E$. alniaria and $A$. testacea were also captured.

It will be seen that all his species are on our list and that there is still greater evidence for considering $P$. meticulosa as a migrant.

\section{Records of insects at the lightships and lighthouses in Scotland.}

In 1914, 1915 and $1916 \mathrm{~W}$. Evans published a full account of insects captured at certain Scottish lighthouses over a period of about six years. Thirteen lighthouses sent in material and of these seven were in or near the Firth of Forth; the others were on the south-west coast, in the Hebrides, and in the Orkneys and Shetlands. Over 6000 specimens were examined and identified to 164 species of Lepidoptera.

Unfortunately this wealth of material does not throw much light on the subject of migration as nearly all the lights were either on the mainland or, if not, on the islands quite close to the coast or large enough to have their own resident fauna.

For example 101 species are recorded from the Isle of May in the Firth of Forth, about five miles from the Fifeshire coast and nine miles from the East Lothian coast. But the island itself is nearly one mile long and has quite a considerable vegetation. 
The only light to which captures must have flown some considerable distance is the Bell Rock, which is off the Firth of Tay about 11 miles south-east of the coast of Forfarshire. At this light only 4 species were recorded : $X$. monoglypha. 1 male on 12th July. 1915. C. quadripunctata. 1 male on 10th July 1915. P. gamma. 1 male on 8th July 1914. P. maculipennis. A " rush of small moths " believed to be this species in August 1914, but no specimens were kept for identification.

Of these, only C. quadripunctata is not on our list of captures.

\section{Observations on migrant Butterflies in Florida, U.S.A., made by Mr. aNd Mrs. K. Hodges dURING 1937, 1938 aNd 1939.}

\section{By C. B. Williams.}

In May 1937 a letter was received from Mr. and Mrs. Karl Hodges of Indiatlantic-by-the-Sea, Melbourne, Florida, with a full account of a migration of Ascia monuste and an offer of help for further observations, which was gratefully accepted.

Specimens of many species were sent to Rothamsted for idéntification, and named ones were returned to the observers so that they rapidly got to know the more conspicuous species.

During the remainder of $1937 \mathrm{Mr}$. and Mrs. Hodges sent in other general observations on movements, and at the beginning of March 1938 they started an almost daily watch which was continued until November.1939. Each day a smaller or larger number of butterflies was caught and placed in an envelope, on the outside of which were written notes on the temperature, wind, weather, the species observed and the direction of their flight. These have been sorted out and tabulated, and form a unique series of observations giving information on several new migrants as well as on butterflies whose migration was already established.

Altogether nearly 2200 specimens have been sent in, so that there has been a very frequent check on all the identifications. Fortunately the principal migrants of this area are easy to distinguish from related species, but some difficulty has been experienced in separating the "Skippers" (HESPERIDAE) and the observations on these are not given in full here.

The locality where almost all the observations have been made is Indiatlantic-by-the-Sea, which is on the Atlantic coast of Florida, on the long narrow island which is separated from the mainland by the so-called "Indian River," really a lagoon. The nearest town is Melbourne, a few miles due west, which is itself about 60 miles S.E. of Orlando. The island is at this point about 2 miles wide and the Indian River about the same width. Most of the observations were made within a quarter of a mile of the shore but a few were made on the banks of the Indian River or from the bridge which crosses it.

Owing to the immediate vicinity of the Atlantic Ocean to the east almost all records of flight are either to the north or to the south. No butterflies could be flying from east to west as they would have to come out of the ocean, and the butterflies observed showed no tendency to fly out to sea to the east.

I would like to take this opportunity of thanking Mr. and Mrs. Hodges for the great enthusiasm and intelligence they have shown in making the observations.

In fig. 9 are shown diagrammatically the days on which observations were taken and the direction of the wind whenever mentioned. Between the 7 th 
March 1938 and the 31st October 1939, observations on insects were made on 576 days. On 45 of them the wind was not noted, on 100 of the remainder it was stated to be "calm," or " no wind." During the 431 windy days the wind was from the S.E. on 173 days or about $40 \%$; the next most frequent directions being N.E. and E. These three directions, all from the easterly quarter, account for $75 \%$ of all the days with wind. On the other hand, on only 57 days $(13 \%)$ were the winds from the W., N.W. and S.W.

An examination of the records for each month shows that the prevalence of S.E. winds is most marked from February to September inclusive. From

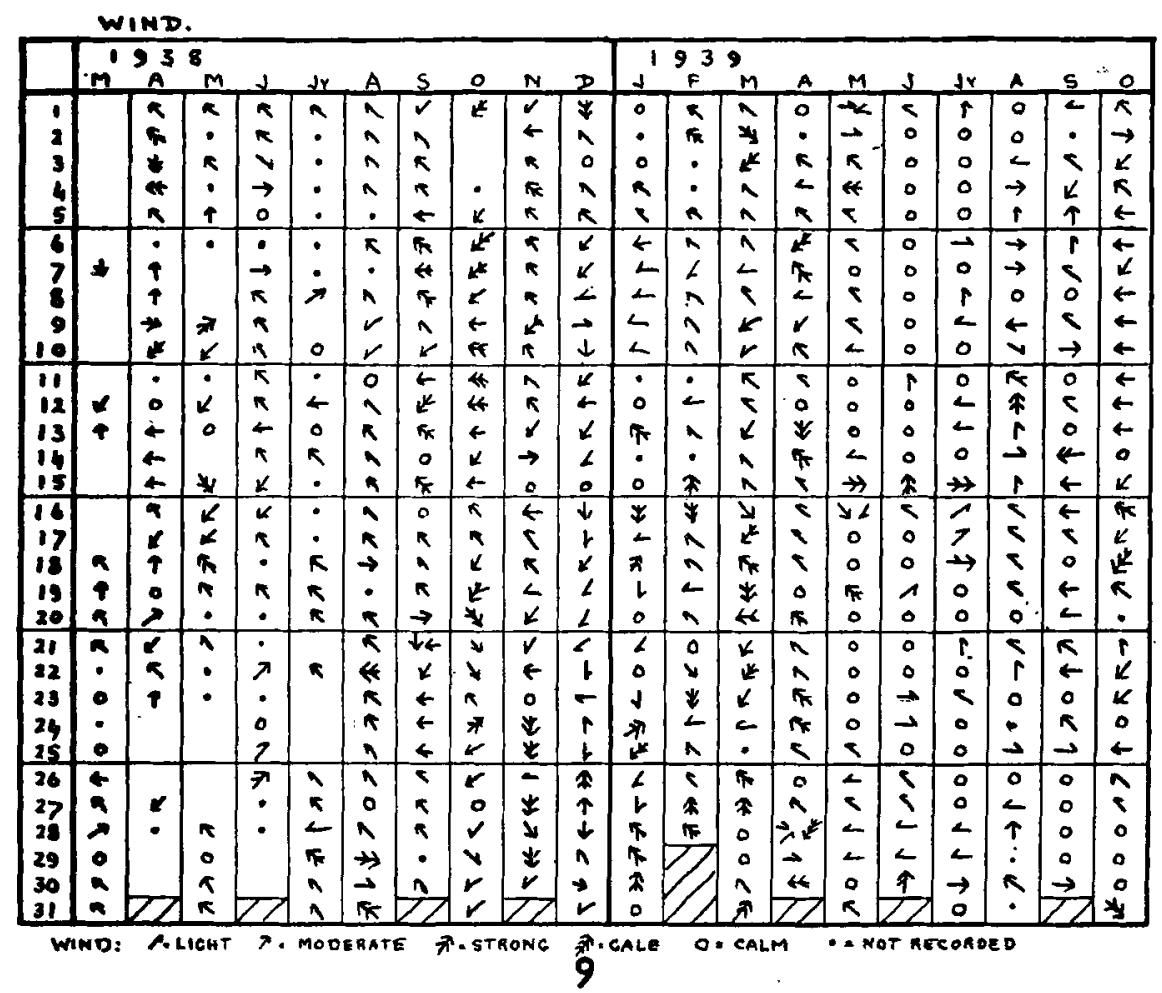

Fra. 9.-Direction of wind during the period of observations of migrant butterflies made by. Mr. and Mrs. Hodges in Florida.

October to January the most prevalent wind is from the N.E., with E. and S.E. next in occurrence.

Ascia monuste L. (The Great Southern White).

In a recent paper (Williams $1938 \mathrm{~b}$ ) the information available on the migrations of this butterfly in the U.S.A. was summarised. There was a number of records almost all along the Atlantic coast of Florida and nearly all in the months of April to June. About 24 records from localities south of New Smyrna (lat. $29 \cdot 3^{\circ} \mathrm{N}$.) were all in a southerly direction, while about a dozen records north of New Smyrna were more frequently to the north than to the south but included both directions. The information appeared to support a theory that there was some point of origin of the swarms about the latitude 
of New Smyrna from which migrations went both to the north and to the south.

Mr. and Mrs. Hodges' records during 1937 were included in this summary. In this year they observed a movement towards the south at Indiatlantic Beach from the end of May to the end of July; but they noted that on the 5th and 6th of July only the flight changed direction and went towards the north. Not one butterfly was seen from the end of July until the early spring of 1938.

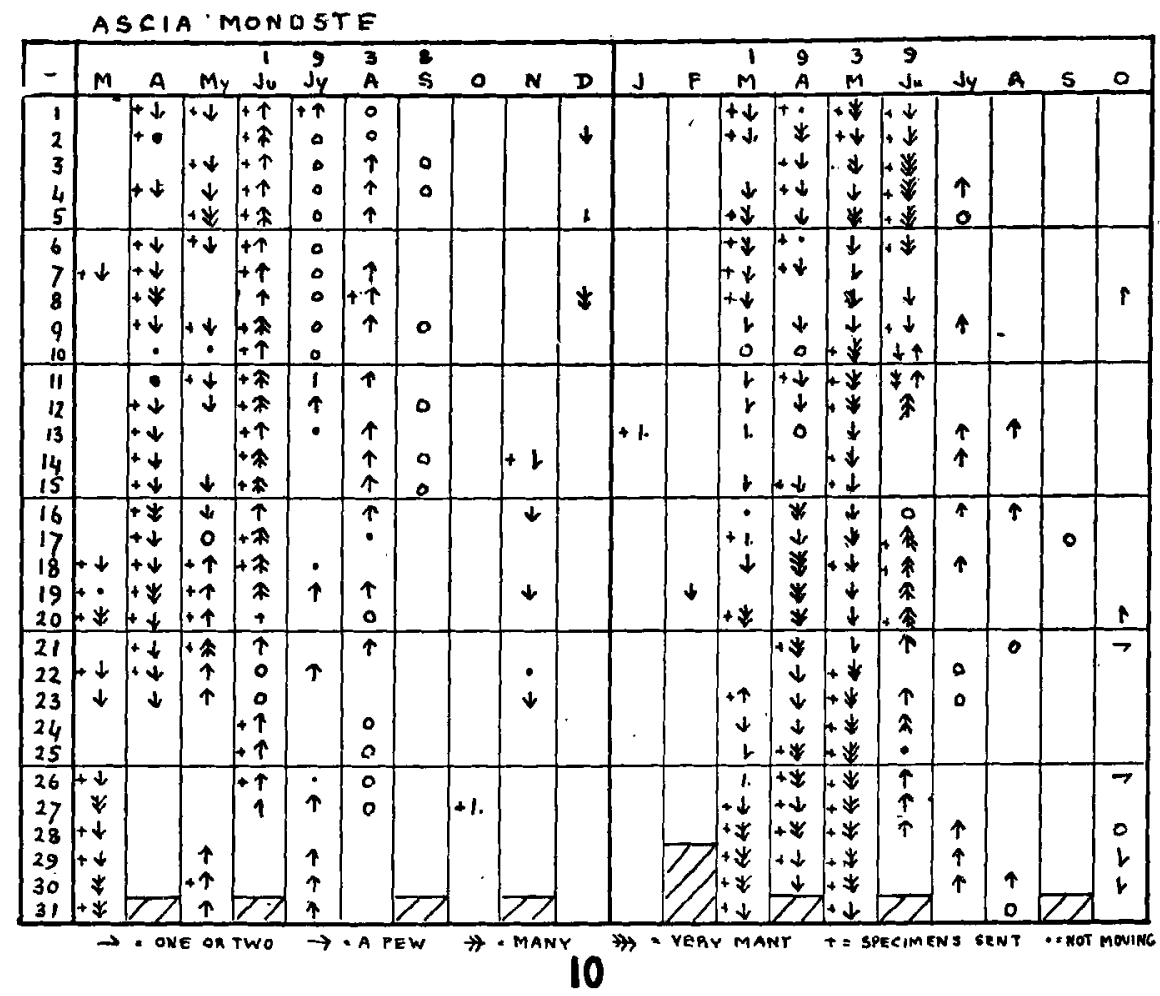

Fig. 10.--Observations by Mr. and Mrs. Hodges in Florida on the movements of Ascia monuste.

In 1938 the first one caught was on the 7th March and the observations from then on are tabulated in fig. 10. The results in the first half of 1938 are very striking and unexpected. A. monuste flew southward in very large numbers almost every fine day from the end of March to the 16th May. Then, after no butterflies seen on the 17th, the flight resumed on the 18th in the exactly opposite direction, towards the north, and continued in this direction quite markedly during the whole of June, with occasional individuals during July and the first half of August, all to the north.

From the 21st August no butterflies were seen until a single one on the 27 th October and a few scattered individuals, mostly apparently moving to the south, in November and December.

The species did not become abundant again until the beginning of March 1939, when the southward flight set in and continued without a break until 
the 9th June, with specially heavy flights about the 18th April, the 10th and 25th May and the 3rd-5th June. On the 10th and 11th June individuals were seen going both to the north and to the south. On the 12 th June a very definite flight set in towards the north, which lasted throughout June in considerable numbers and was noticed in small numbers on several days in July and occasionally throughout August. None was noticed in September and only one or two individuals in October flying in various directions.

TABLE 15.

Numbers of white, intermediate, and grey individuals of $A$. monuste captured at different times of the year in Florida. The row of crosses xxx indicates the time of reversal of flight direction.

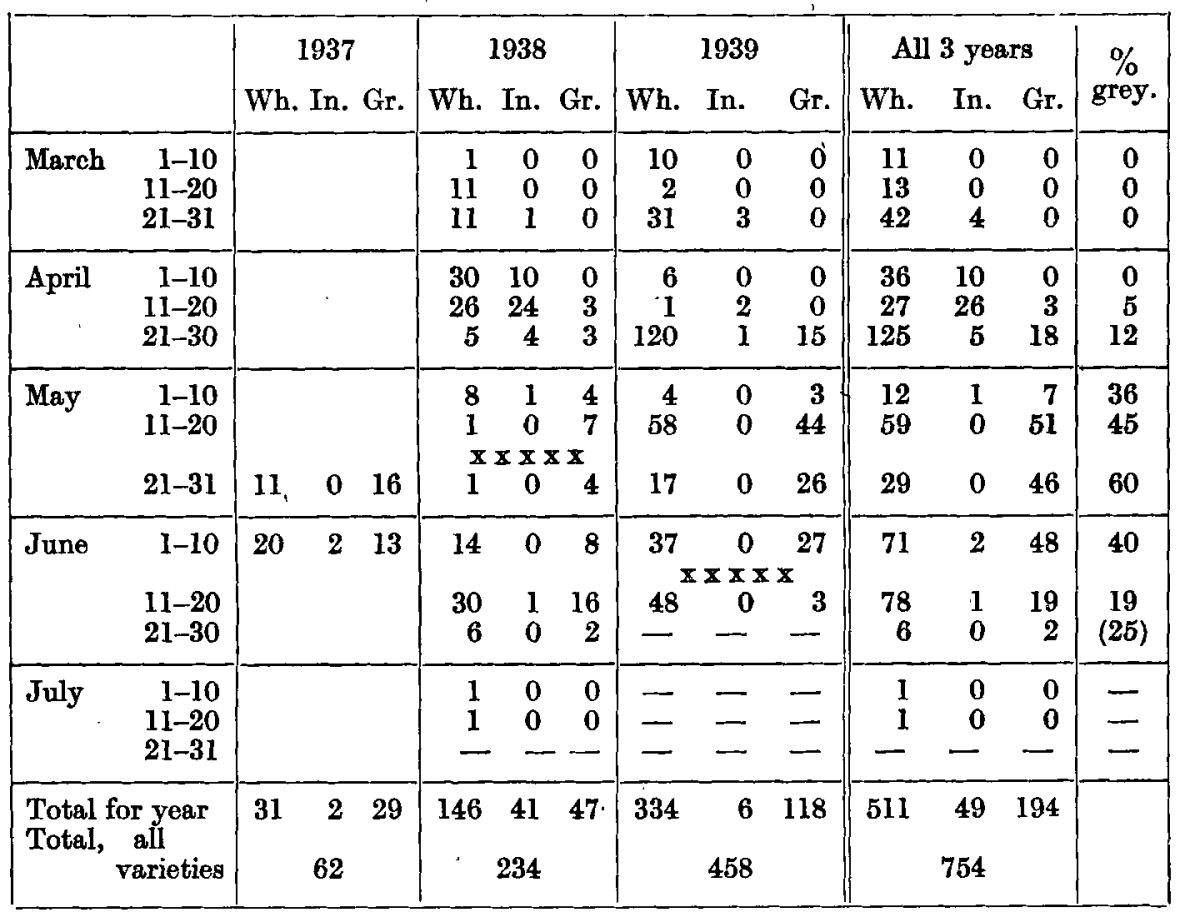

Thus in 1937 there was evidence of a change of direction from the southerly to the northerly flight for two days at the beginning of July; in 1938 the direction changed definitely and permanently after the 18th May; and in 1939 the same change happened on and after the 9th and 10th June.

The species $A$. monuste is always white in the male sex, but the female can be either white or grey (form phileta Fabr.) or more rarely intermediate in colour.

In the course of the three years Mr. and Mrs. Forbes sent over seven hundred and fifty specimens for examination and the proportion of the whites, intermediates and greys is shown in Table 15. Unfortunately it is very difficult and sometimes impossible to distinguish between the white males and the white females in the dried and somewhat rubbed material available for study.

TRANS. R. ENT. SOC. LOND. 92. PART 1. (JULY 1942.) 
It will be seen that neither grey nor intermediate forms are present at the beginning of March, all specimens sent being white. In the last week in March a few intermediates begin to appear and by the second week in April full grey females are found in small numbers. The percentage of these to the total population rises rapidly to a maximum of about $60 \%$ in the last week in May and then falls again during June. The exact extent of the fall. is uncertain as only a few specimens were captured after the second week in June.

In 1938 the specimens captured in the second half of May, just after the change of direction from south to north, were 2 whites and 11 greys-a considerably higher proportion of greys than had been present in the weeks before the change of direction.

In 1939, on the contrary, the specimens caught in the second ten days of June just after the change of direction were 48 whites and only 3 greys, a very sudden drop in the proportion of greys. The evidence is contradictory but does not seem to support the idea that the same individuals that have gone south turn round and come north again.

After the end of July very few specimens were captured. They included one grey in August 1939 and one white in October and November 1938 and in January and October 1939.

There is a small amount of evidence that the whites and the greys keep apart in the flights; thus Mr. and Mrs. Hodges write on 3rd May 1939: "The grey females have been fewer this year and it was not until the 28th April that they appeared in any numbers. We netted many in the morning flying south with the whites but in their own column. They were flying in about equal numbers with the whites." Again they say, speaking of the same date: "Whites and greys flying about 60 per minute. Nearly all the greys in this envelope were netted in single column without whites."

Mr. and Mrs. Hodges made also many general observations on the flights, of which the following might be quoted to give some idea of the migration at its height:-

"On Wednesday, 26th April 1939, the whites were flying south all day in single column from the Indian River to within about 100 yards of the Atlantic Ocean beach, which we call the 'Beach Lane'. Here the butterflies spread out in a blanket of white several yards wide, flying fast. Over a hundred per minute passed just like a cloud in the morning, while in the afternoon they increased to at least 300 per minute for a width of over 300 feet. Close to the rim of the ocean was another column with Ocean Drive separating it from the last described.

"At intervals within the space of a mile all those on the east side of the drive had crossed until only a single column was left to pass through Melbourne Beach Town, all others joining and flying on towards Sebastian Inlet some twenty miles south.

"In this flight only a few greys could be seen. All were flying from 2-5 feet from the ground at a speed of about 25 miles per hour. They would fly into the net as you held it in front of them and were so close that five or six or more"were netted at one sweep."

The observations just summarised do not support the suggestion made in the Ifirst paragraph (p. 143) that the flights originated in the New Smyrna district and from there spread both north and south. Although these new observations relate to only one locality, they extend very considerably to the south the area where northerly flights occur, and show that a definite change of direction can occur in a single locality. 


\section{Danaus plexippus.}

In 1937 two specimens were captured on 31st May, but at the end of September Mr. and.Mrs. Hodges reported that altogether they had seen only these two. Individuals were again seen, flying to the south, on 13 th and 30 th October and on 5th and 9th November 1937. On the latter day they reported Monarchs flying to the south 3-20 feet above the ground.

No others were noted till the 5th April 1938 and the observations from this date are summarised in fig. 11. From the 20th April to the 12th May a few were seen going north but from that date till 4th October not a single one was observed. On this date, however, they reappeared in numbers and there was

DANAUS PLEXIPPUS

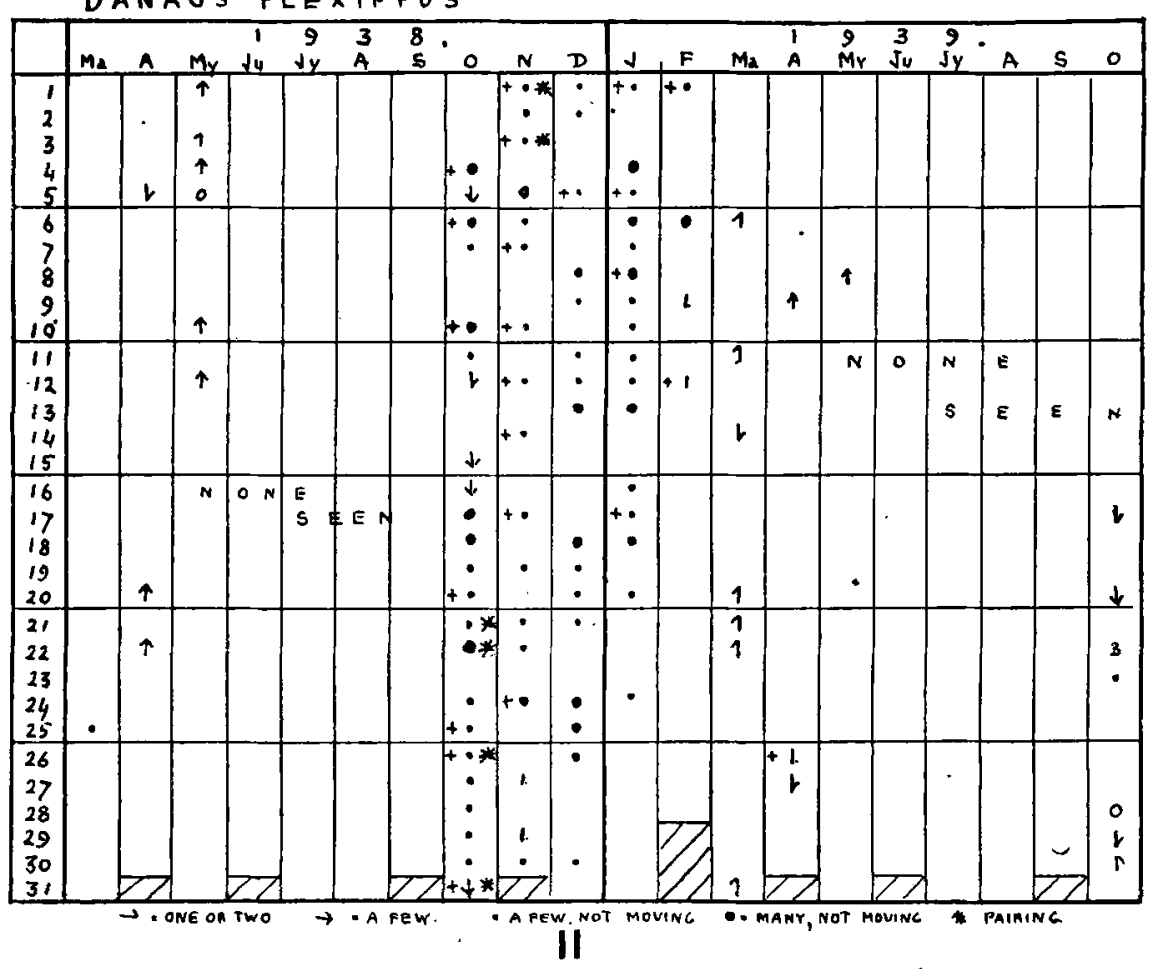

Frc. 11.-Observations by Mr. and Mrs. Hodges in Florida on the movements of D. plexippus.

some evidence of a southward drift during October. They remained in the neighbourhood in moderate numbers throughout the winter and were again seen going north in small numbers during March and April 1939, and the last individual was seen on the 8th May also going north. They reappeared in the autumn on the 17th October and were seen in small numbers during the rest of October, most moving to the south.

The dates of first appearances in the autumn were thus 13th October in 1937,5 th October in 1938, and 17th October in 1939; and the last appearances in the spring were 31st May in 1937, 12th May in 1938 and 8th May in 1939. 938.

Pairing was noticed at the end of October and the beginning of November 
The evidence is entirely consistent with the theory of an autumn migration into Florida from the north and a return flight to the north in the spring.

About 42 specimens were captured which were all of the typical North American type with the spots just beyond the cell in the fore-wing pale buff, and distinct red-brown markings in the dark apex of the wing (see p. 156). There is no evidence from this material of the presence in Florida of the Central American type which is believed to be non-migratory. There seems also to be little evidence of a resident population remaining in the Melbourne District of Florida during the simmer.

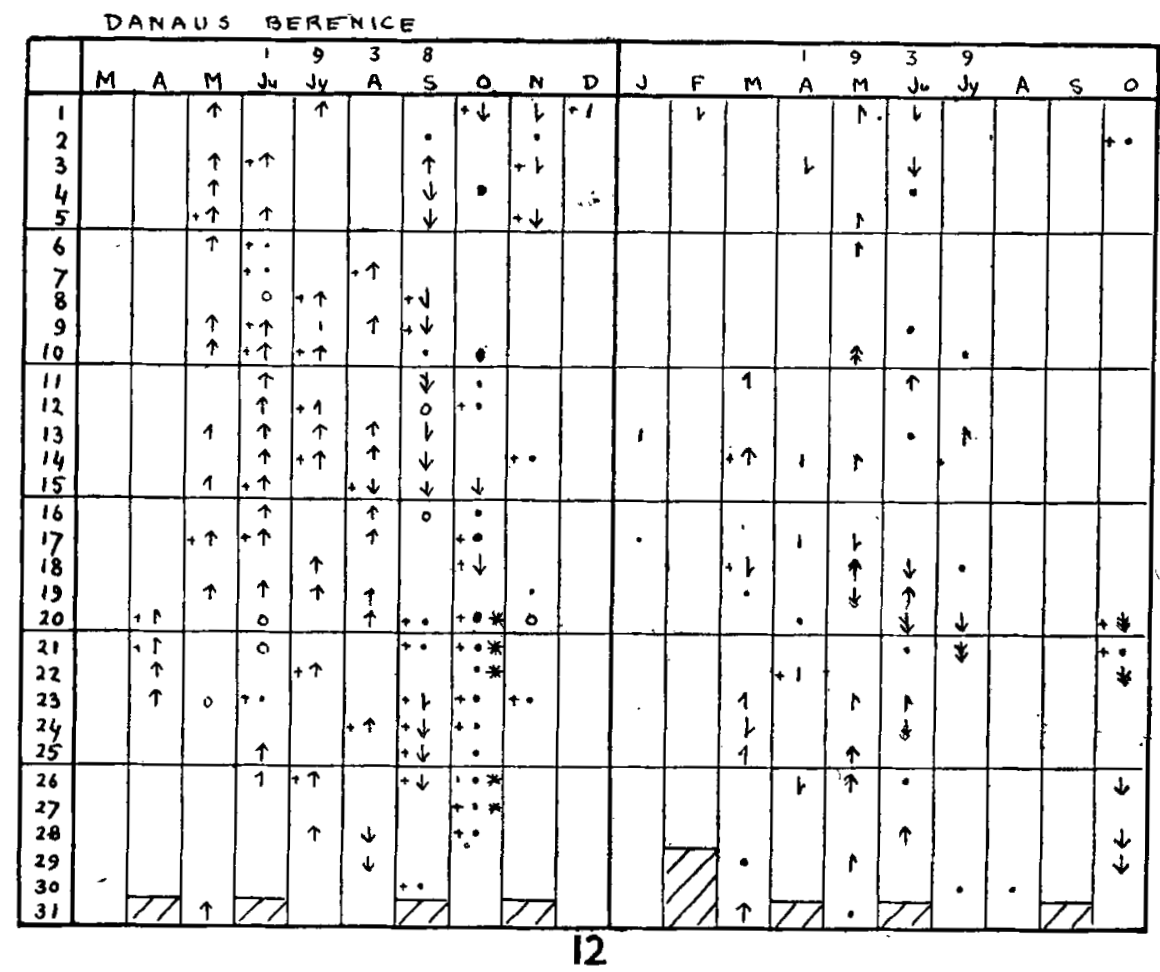

Fic. 12.-Observations by Mr. and Mrs. Hodges in Florida on the movements of 'D. berenice.

\section{Danaus berenice.}

Previous to the observations of Mr. and Mrs. Hodges the only indication that $D$. berenice could migrate was in an old record by Maynard (1886, The Butterfies of New England, Boston : 8), who wrote: "I saw hundreds of $D$. berenice flying to the east over the Atlantic 50 miles from land." No date or locality was given.

Mr. and Mrs. Hodges' records in 1937 showed that the species was present in large numbers about the 14th July flying over flowers and easy to net. Most had gone by 2 nd August but it appeared in smaller numbers at least up to 16th September.

Regular observations were started in 1938 and the results are shown in fig. 12. It will be seen that in 1938 there is a very definite movement to the 
north throughout April, May, June and July. During August, flights in both directions were noted, and from the beginning of September an equally definite southerly movement set in which was noticeable until early November. Pairing was noticed at the end of October. Only an occasional individual was noticed from the 5th November till the middle of March 1939. Then they became more common during March and April but with little indication of a northerly movement up to the beginning of May. During May, however, small numbers were recorded as flying to the north, particularly on the 10th. During June and July small numbers were seen sometimes flying to the north and at

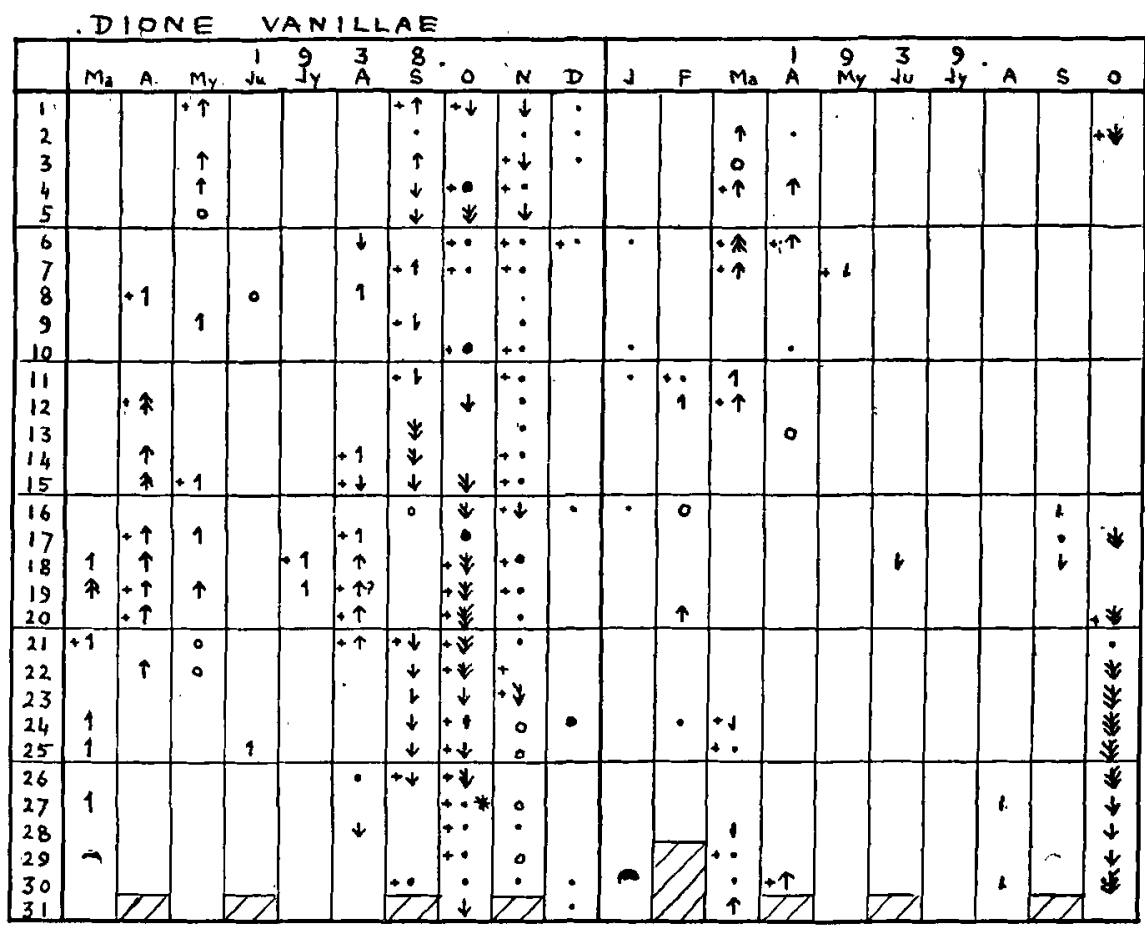

13

Fra. 13.-Observations by Mr. and Mrs. Hodges in Florida on the movements of Dione vanillae.

other times to the south. Only three individuals were seen between the 22 nd. $J$ uly and the 19th October but on the 20th October there was a steady movement to the south which continued with some breaks to the end of the month.

Nearly 100 specimens were sent in at intervals to check the identification and all were $D$. berenice.

The observations lend quite definite support to the idea of a northerly movement in the spring and a southerly movement in the autumn in Florida.

\section{Dione vanillae.}

The first specimen captured by Mr. and Mrs. Hodges was on 28th August 1937 , and they report that from that day to the 23rd September many appeared each day flying to the south. 
Four specimens were captured on the 8 th September and single ones on the 14th and 15th October and the 3rd November-all these were moving to the south.

There is no other record until the 18th March, when a single one was seen going to the north, followed on the next day by a record of "many going to the North." The records from this date are shown in fig. 13.

It will be seen that there was in 1938 a regular movement to the north during March, April and May; single specimens only were seen in June and July, becoming a little commoner again in August; and finally a very definite

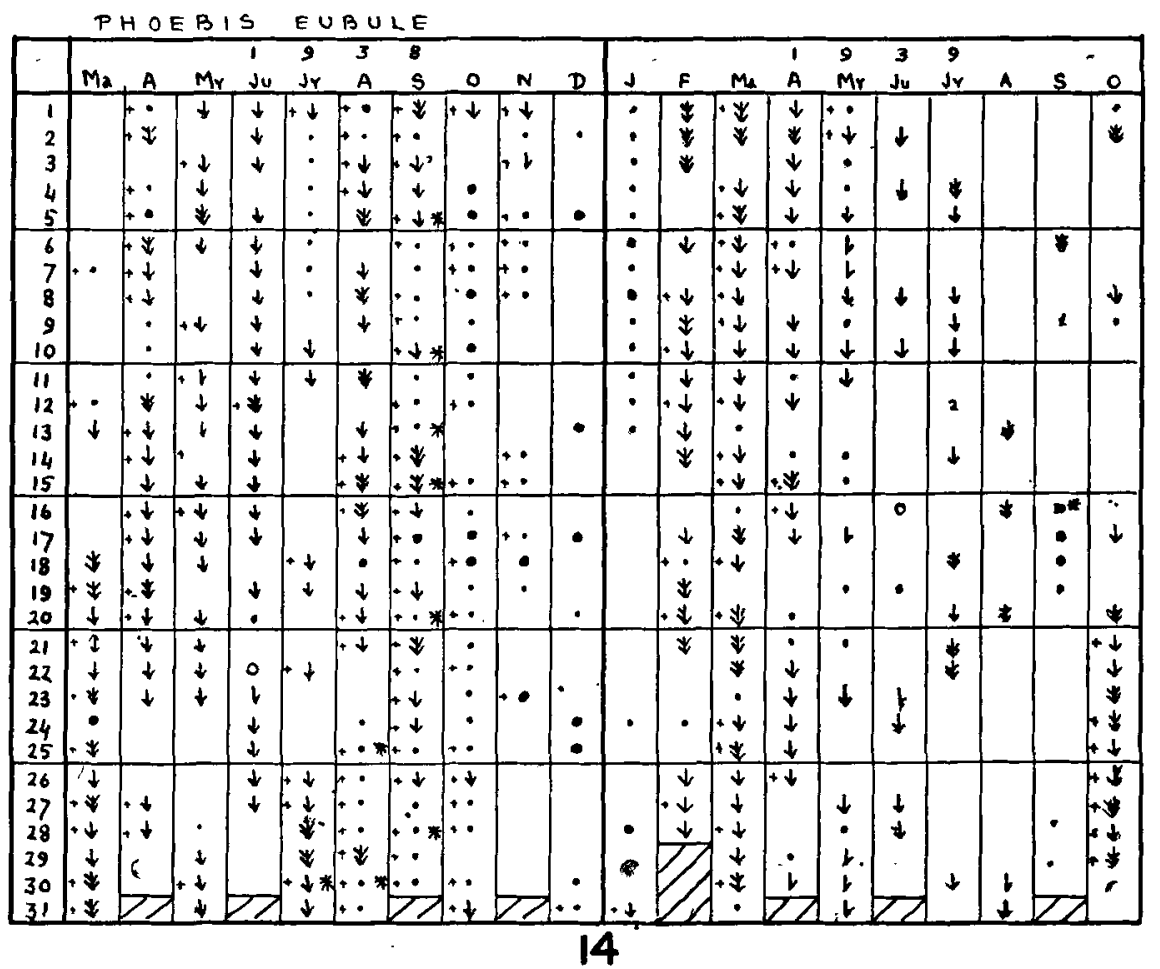

Fiq. 14.-Observations by Mr. and Mrs. Hodges in Florida on the movements of Phoebis eubule.

southerly movement in September and October, becoming much less distinct in November.

No butterflies were then seen from the 23rd November 1938 till the 12th February 1939, when one was going to the north. During March and April 1939 there was again a definite movement to the north, but this did not appear to be as large as in 1938. Only two individuals were noted between the beginning of May and the 27th August (one in May and one in June); two were seen in the last week in August, a few in mid-September, a number flying south at the beginning of October and then about the-middle of October a large southerly flight developed, which, on the 24th October, reached an intensity of 120 butterflies per minute within sight.

Previous to these observations, $D$. vanillae had been recorded taking part 
in directional flights in the Galapagos Islands and in the Argentine, but there was only a single record for N. America when Johnson (1899, Ent. News $10: 21)$ referred to a flight in Florida in September towards the south, but gave no year or further details.

There appears to be no doubt that this species has in Florida a regular movement towards the north in spring and a very definite movement in large numbers towards the south in autumn.

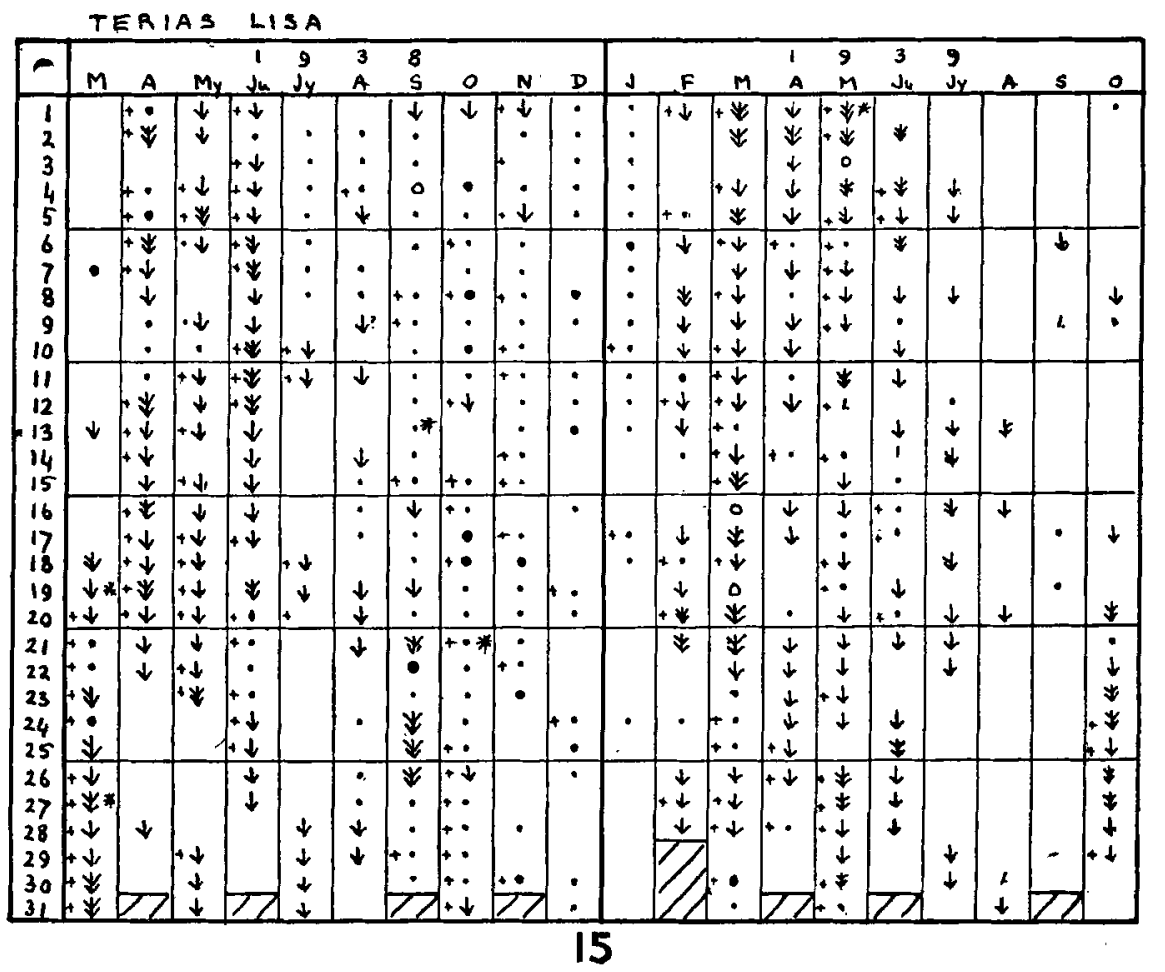

FIa. 15.-Observations by Mr. and Mrs. Hodges in Florida on the movements of Terias lisa.

Phoebis eubule.

This is a well-known migrant and records of ${ }^{*}$ directional flights are known in the United States, in Tropical America and as far south as the Argentine. Previous information (Williams 1938 b) indicated that in the U.S.A. there is a very definite southerly or south-easterly movement in the autumn and a much smaller one towards the north or north-west in the spring (see p. 188). In the Argentine northerly movements have been recorded in the autumn but there is so far no record of a spring movement away from the Equator (Williams 1930b).

With this information in hand, the observations made by $\mathrm{Mr}$. and Mrs. Hodges are very puzzling, as they observed almost continuous flights towards the south throughout most of the year.

In 1937, they reported eubule going south along with a big flight of $\boldsymbol{P}$. monuste at the end of May. In mid-August they wrote: "Nearly every day 
we note large yellows fying about with general direction south." On 23rd September: "Still the movement to the south continues," and later that during December 1937 and January and February 1938 the movement south continued whenever there was not a cold wind or heavy cloud. The observations from March 1938 are tabulated in fig. 14 and show movement to the south in all months except perhaps October to January.

Pairing was noted once during July, once in June, during August, on several occasions during September 1938, and once during September 1939.

The butterfly was present in fair numbers during every month of the year.

Up to April 1933 they had sent 313 specimens, of which 140 were males and

PAPILIO CAESPHONTES

\begin{tabular}{|c|c|c|c|c|c|c|c|c|c|c|c|c|c|c|c|c|c|c|c|c|}
\hline 1 & $M$ & $A$ & $m$ & $\begin{array}{l}1 \\
20\end{array}$ & $\begin{array}{c}9 \\
\mathrm{Jy}\end{array}$ & $\begin{array}{l}3 \\
A\end{array}$ & $\begin{array}{l}8 \\
5 \\
\end{array}$ & 0 & $\mathbf{N}$ & $D$ & 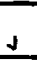 & $\boldsymbol{F}$ & $\begin{array}{c}1 \\
M\end{array}$ & A & $\begin{array}{l}3 \\
M\end{array}$ & 9 & dr & A & $s$ & 0 \\
\hline $\begin{array}{l}1 \\
2 \\
3 \\
4 \\
5\end{array}$ & & & $\begin{array}{r}+\uparrow \\
\uparrow \\
\uparrow \\
\uparrow\end{array}$ & $\uparrow$ & & & & & & & & & $\begin{array}{r}\uparrow \\
+\uparrow\end{array}$ & 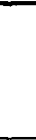 & $\begin{array}{r}1 \\
+\uparrow \\
+\end{array}$ & 1. & 1 & & & \\
\hline $\begin{array}{r}6 \\
7 \\
8 \\
9 \\
10 \\
\end{array}$ & & & $\uparrow$ & $\uparrow$ & & & & $\bullet$ & & & & $\begin{array}{l}1 \\
1\end{array}$ & $\dot{\imath}$ & $r$ & $\begin{array}{l}t \\
t \\
t\end{array}$ & & I. & & $f$ & \\
\hline $\begin{array}{l}11 \\
12 \\
13 \\
14 \\
15\end{array}$ & & $\begin{array}{r}+1 \\
\uparrow \\
1 \\
4\end{array}$ & $\begin{array}{l}+\uparrow \\
+\uparrow\end{array}$ & & & & & & & & & $\begin{array}{l}1 \\
\uparrow\end{array}$ & $+i$ & & $\begin{array}{l}1 \\
1 \\
1\end{array}$ & & & & & \\
\hline $\begin{array}{l}16 \\
17 \\
18 \\
19 \\
20 \\
\end{array}$ & & $\begin{array}{r}+1 \\
+\uparrow \\
+\uparrow \\
+\uparrow \\
+\uparrow\end{array}$ & $\begin{array}{r}1 \\
4 \\
1\end{array}$ & $\begin{array}{l}\downarrow \\
\downarrow \\
\downarrow\end{array}$ & 1 & & & & & & & 1 & & & 1 & $f$ & & & • & 1 \\
\hline $\begin{array}{l}21 \\
22 \\
23 \\
24 \\
25\end{array}$ & & $\begin{array}{l}-1 \\
1\end{array}$ & $\stackrel{\uparrow}{\bullet}$ & & & & & & & & & $\uparrow$ & +1 & - & $i$ & & & & & 1. \\
\hline $\begin{array}{l}26 \\
27 \\
28 \\
29 \\
30 \\
31\end{array}$ & - & $\begin{array}{c}+\uparrow \\
+\uparrow\end{array}$ & 1 & L & $r$ & & $b$ & +1 & 77 & & & 1 & & $Z 7$ & $\begin{array}{l}1 \\
t \\
t\end{array}$ & $Z 2$ & i & & 27 & 1 \\
\hline
\end{tabular}

16

Fig. 16.-Observations by Mr. and Mrs. Hodges in Florida on the movements of Papilio cresphontes.

173 females. Both sexes were present in every month when more than one individual was caught and in general they were in more or less even proportion. The following larger departures from equality are noted but they do not appear to be of any significance :-August 1938, 7 males to 28 females; October 1938, 22 males to 11 females and March 1939, 4 males to 19 females.

\section{Terias lisa.}

Previous to the observations of Mr. and Mrs. Hodges, the only evidence of migration in this species was the fact that on several occasions large numbers had appeared suddenly in the Bermuda Islands. 
In $1937 \mathrm{Mr}$. and Mrs. Hodges reported that on the 24th May T. lisa was joining in a southward movement of $A$. monuste. Three specimens were sent. From that time till 20th September they were generally common and showed a definite tendency to move to the south. In December 1937, January and February 1938, it was again " moving southwards whenever the weather was not wet or cloudy."

The more regular observations after March 1938 are shown in fig. 15 and indicate a continuous movement towards the south which is at its maximum in April, May and June but occurs in all months except November, December and January.

The observations on Terias lisa thus closely resemble those on Catopsilia eubule, which also appears to move only to the south in this locality. No explanation can yet be put forward and more observations are required especially in Florida away from the coast line.

The identification was checked from nearly 300 specimens sent at intervals during the two years.

\section{Papilio cresphontes.}

I have been able to trace only one record of directional movement in the "Giant Swallow tail," previous to the observations of Mr. and Mrs. Hodges. Saverner (1908) recorded it flying south on Lake Erie, Canada, in August and September 1907 with Papilio troilus and Danaus plexippus.

Mr. and Mrs. Hodges noted it moving in small numbers on many occasions which are tabulated in fig. 16 . The records indicate a definite movement to the north in the spring of both 1938 and 1939.

Only very rarely, however, was the butterfly seen in the autumn and there is at present no evidence in support of a return flight at this time of the year.

About 20 specimens were captured at intervals and sent in for confirmation of the identifications.

\section{Eudamus proteus.}

According to Scudder $(1889: 1333)$ this Hesperid butterfly, known as the "Long-tailed Skipper," is a typical southern species which occasionally appears in some numbers in the south-western corner of New England.

Mr. and Mrs. Hodges first recorded it in September 1937 as migrating south from the 12 th to 20 th of that month, 2 to 3 feet above the ground, during clear warm weather with winds chiefly from the S.E.

No other observation was made till September of 1938, from which date the records are tabulated in fig. 17. It will be seen that there was again a definite movement to the south between the 16th September and the 5th November. Pairing was observed on the 21 st, 22 nd and 23 rd October.

The insect remained in this neighbourhood throughout the winter without any direction movement, but in February and March movement was again noted; not in any fixed direction, sometimes to the north and sometimes to the south.

There were a few records of southward flight in July and August of 1939 but no extensive movement till the end of October when the southward flight set in in large numbers.

Thus a definite southward flight has occurred in the autumn of all the three years during which observations have been made. 
Vanessa virginiensis Drury (= huntera F.).

The first specimen of this species, known as "Hunter's Painted Lady," sent by $\mathrm{Mr}_{\text {: }}$ and Mrs. Hodges was captured on 2nd April, 1938.

No other observation was made until 30th September, when another specimen was sent with the remark: "Many are going south."

On 27th February 1939 one was " netted on flowers about noon."

The next observations were made from 23rd to 25th March 1939. Mr. and

EUDAMUS PROTEUS

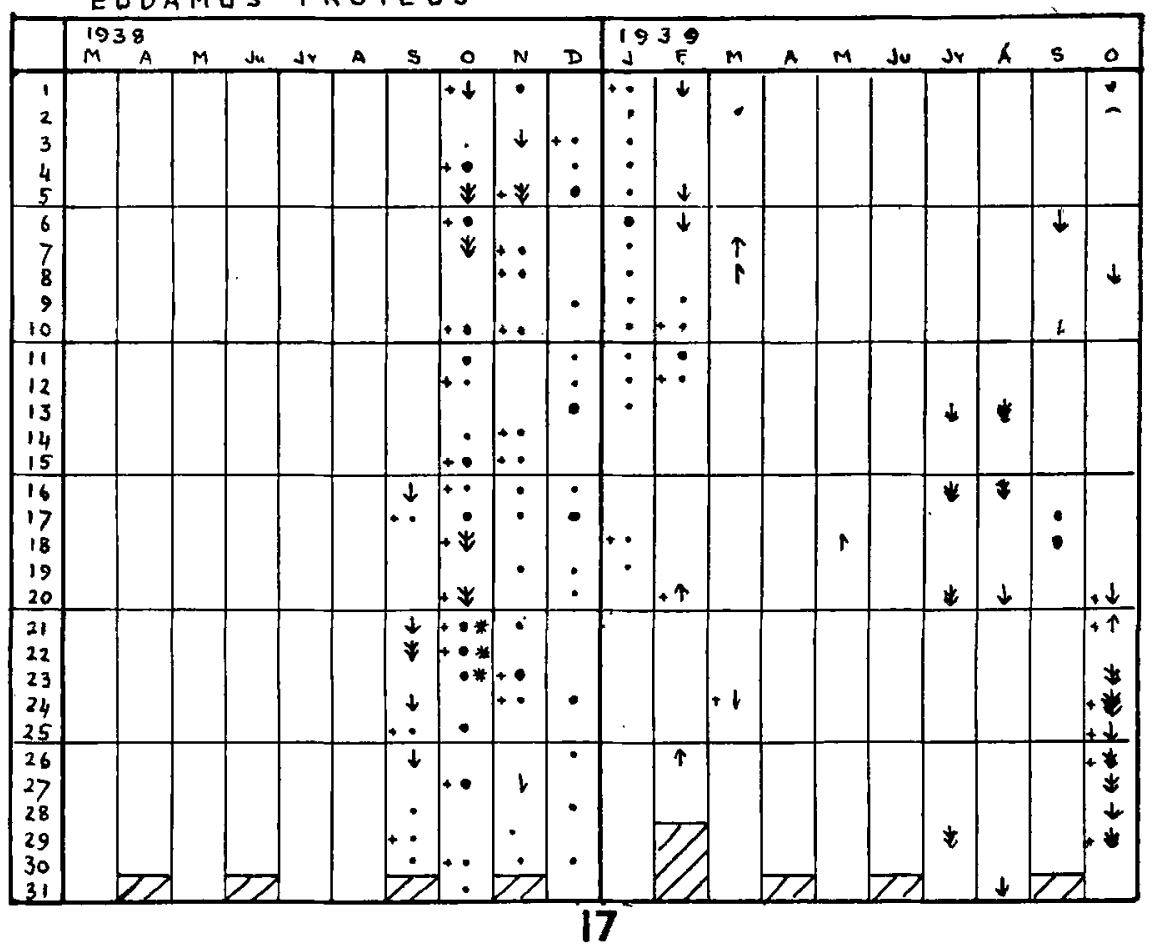

Fia. 17.-Observations by Mr. and Mrs. Hodges in Florida on the movements of Eudamus proteus.

Mrs. Hodges write that on the 23rd March " we discovered two other movements to the north, one a brown butterfly. ... On the next day we saw many and netted one by the Indian River."

Additional notes were that on the 23rd March the butterflies were flying " above the whites ( $A$. monuste) about 15 feet from the ground and very fast30 m.p.h. to the north."

On the 24th they were "going all day in single column 20 m.p.h."

On the 25th "Several seen going north fast in single column."

Finally on 31st March another was captured on the east bank of the Indian River and sent with the note "About one every minute going north with Whites (A. monuste), occasional Queens (D.berenice), and Gulf Fritillaries (D. vanillae)."

To sum up, no specimens were seen except in the spring and autumn and there is distinct evidence of a northward flight in the spring and a southward flight in the autumn. 
It is remarkable that not a single specimen of Vanessa cardui was sent by Mr. and Mrs. Hodges, but on the other hand neither in 1937 nor in 1938 was the Painted Lady present in large numbers in the U.S.A. generally.

The problem as to whether this latter species enters the U.S.A. through the West Indies and Florida is of considerable interest (see Williams 1938b). At present the only evidence of migration of $V$. cardui in Florida is that early in May 1916 near Key West, Mr. Honoré, a visitor from Europe, found himself surrounded by butterflies which he identified as $V$. cardui because they were similar to the European species with which he was familiar. No specimens were captured and, in view of Mr. and Mrs. Hodges' observations on the occurrence and movements of Vanessa virginiensis, it must be recognised that Mr. Honoré may have mistaken this latter for V. cardui. Further observations on the occurrence of both species in Florida are greatly needed.

I have been able to find only one other record of migration of $V$. virginiensis in U.S.A. and that is by Shannon (Amer. Mus. J. 17:33-40), who states that at Long Beach, Long Island, N.Y., in August and September 1919 numbers were flying steadily to the west in company with many $D$. plexippus and various dragonflies.

It is interesting to note that the butterfly has been recorded on five occasions in the British Isles : once in Ireland, once in South Wales, twice on the south coast of England, and one specimen in the Dale collection without exact locality but stated to be British.

\section{Vanessa atalanta.}

On 30th March 1939 Mr. and Mrs. Hodges report "we noticed a butterfly flying fast to north; also on 3lst March we watched them but they were too high up to net, until two flew lower than the others. One settled on the blossom of an Oleander bush and was captured. Estimated numbers flying one every half hour to the north for two days."

The specimen was the Red Admiral, Vanessa atalanta, and this was the only occasion on which this species was sent to me. It is a well-known migrant in Europe but there is only one previous record (Davis 1912) of a directional movement in North America.

\section{SUMmarised ObSERVATIONS ON SPECIAL SPECIES.}

\section{By C. B. Williams.}

(1) Danaus plexippus.

\section{Variation and geographical distribution.}

The Monarch butterfly extends, in one or other of its forms, from Alaska and Hudson Bay in North America to Patagonia in the south. There are, however, colour and pattern differences which enable individuals coming from certain areas to be distinguished from those coming from elsewhere.

The main differences are found in the fore-wing; first in the presence or absence of the dark bar along the hind margin of the wing; secondly in the colour of the four or five larger spots near the tip of the wing, which vary in colour from white to buff; and thirdly in the extent of the development of redbrown areas in the dark scaling near the tip of the wing. These are in addition to slight sexual differences (Plate 1). 
Owing to the work of A. H. Clark (1931 and 1932) at Washington, Forbes (1939) at Cornell and Talbot at the British Museum, one can now recognise three moderately distinct forms with fairly definite geographical distributions and one series of intermediate forms found chiefly in the area where two of these forms overlap. ${ }^{1}$

The race in South America south of the Amazon is perhaps the most definite and has been considered as a distinct species by many writers. It is characterised by the absence of the dark bar along the hind margin of the front wing (Plate 1, C). This bar is present in all the other forms.

At the other end of the range in North America there is a race in which the spots in the fore-wing are very distinctly buff in colour and the red-brown areas beyond the spots are distinct and well developed (Plate 1, A).

In the northern portion of South America there is a Tropical American form in which the bar at the hind margin of the fore-wings is present, the spots across the apex of the fore-wing are white, and the red-brown areas near the tip are absent, this area being uniformly almost black-brown (Plate 1, B).

$I$ have not yet seen any specimens intermediate between the forms in the south and the north of South America but in the West Indies, in Panama and occasionally on the north coast of South America individuals occur which are definitely intermediate between the North American and the Tropical American races. These may have the spots white but with distinct traces of the red-brown areas; or may have the spots or some of them buff in colour but with the redbrown areas absent.

It is not the purpose of the present paper to enter into controversies of nomenclature but for reference that adopted by each of the authorities already mentioned is given below. For purposes of description I will use the nomenclature of Clark.

\begin{tabular}{|c|c|c|c|}
\hline Race & Clark & Forbes & Talbot \\
\hline 1. N. American & - plexippus & menippe & plexippus \\
\hline 2. Intermediate & . $\quad 4$ & - & megalippe \\
\hline 3. Tropical American & - nigrippus & megalippe & nigrippus \\
\hline $\begin{array}{l}\text { 4. South American . } \\
\text { Whole range }\end{array}$ & - $\quad$ Danpuus plexippus & $\begin{array}{l}\text { erippas } \\
\text { Danaus erippus }\end{array}$ & $\begin{array}{l}\text { erippus } \\
\text { Danaus plexippus }\end{array}$ \\
\hline
\end{tabular}

I have examined over 1000 specimens of this butterfly in my own possession and in the collections at the British Museum, Tring, Oxford and Munich and the distributions of the different races as shown by these specimens are shown in the map (fig. $18 \mathrm{~A}-\mathrm{D}$ ).

It will be seen that erippus ranges from Brazil south of the Amazon southwards to North Patagonia, and westward to the Andes in Bolivia and in the Argentine. I have so far seen only two specimens which might have come from the southern part of the Pacific coast area west of the Andes. These were both labelled "Chile". One is in the collection of the British Museum and is typical erippus; the other is in the Tring collection and is typical North American plexippus. In neither case is the exact locality given or the collector's name, and both specimens are subject to considerable doubt. The insect is said to be not uncommon in Chile by Figueroa (1929) but his figure is copied from a North American journal and does not necessarily represent the form found in Chile.

1 As this paper was in the press an important paper on the variation and geographical distribution of $D$. plexippus by Dr. A. H. Clark has appeared in 1941, Proc. U.S. nat. Mus. 90. It should be consulted by all who are interested in this problem. 
Since the above was written I have received from the Department of Agriculture of Chile, one specimen captured by Mr. F. Ruiz at Las Mercedes, Talca, Chile, in 1925. It is a typical South American erippus. Talca is south of Santiago in latitude $35^{\circ} .20^{\prime} \mathrm{S}$.

It is interesting to note that many of the erippus caught in the Para district of Brazil, near the northern limit of its range, have the spots in the outer portion of the fore-wing white instead of buff, but in none that I have seen do the redbrown areas outside these tend to disappear. Thus both the southern and the northern forms seem to undergo somewhat similar variation as they approach the Equator.

The Tropical American form, so-called nigrippus, is found, according to our map, in Brazil north of the Amazon, in the Guianas, Venezuela and Colombia, and in the west it ranges through Ecuador to Peru, much farther south than the northern limit of erippus in the east. It is also found occasionally in some of the West Indian Islands and according to Clark one has been captured in Florida (18th Dec. 1936), one in N. Carolina (4th July 1938), four in Louisiana (Nov. 1937) and two in West Virginia (15th June and 4th July 1938) (A. H. and L. F. Clark 1938b). These specimens I have not seen and it is possible that they might be classified as intermediates rather than the true nigrippus.

There is one typical nigrippus in the British Museum from the Galapagos.

The intermediate form, which is so variable that I doubt the justification of the use of the varietal name megalippe, is found occasionally in the north of South America and more frequently in the southern portion of Central America and some of the West Indian Islands and occasionally as far north as Mexico.

The northern form plexippus is almost completely dominant in the whole of North America, Mexico, Central America to about the level of Nicaragua, and the Bahamas Islands. It is also found in Cuba, Jamaica, Haiti and some of the Virgin Islands along with intermediates. One specimen which appears to be almost typical plexippus is in the Tring collection labelled Bogota, Colombia.

It is this North American form which appears to have spread over most of the world and all the specimens I have seen from the Pacific Islands, from Australia and New Zealand, from the Azores and Canary Islands in the East, and all but one of the British-caught specimens (see p. 183), are of this type.

It should be noted that in the area populated by the intermediate and nigrippus type the females seem to vary more rapidly towards nigrippus than the males, and in Nicaragua and Costa Rica the females are intermediate while the males are still of the northern type. A variation also occurs in which the wings are very heavily veined and these are nearly all females. In Colombia this appears to be the typical form of the female of nigrippus.

To sum up: there are three forms, a South American, a Tropical American and a North American, with intermediates between the two last. The South American form is known to undertake large migrations and so is the North American, but there is at present no definite evidence of migrations of the tropical form or of the intermediates. The limits of the distribution of these should therefore help to fix the limits of the movements of the two other forms towards the Equator. Thus it would appear that the normal southern limit of the movements of plexippus must be somewhere in Mexico, Cuba and the Bahamas; while the northern limit of erippus is, in the East at least, the Amazon.

So far I have been unable to examine specimens from the large forest area of Central Brazil, and Mr. W. J. Kaye, who has had considerable experience in Tropical America, writes that he considers that the Monarch is never common under such very humid conditions. 


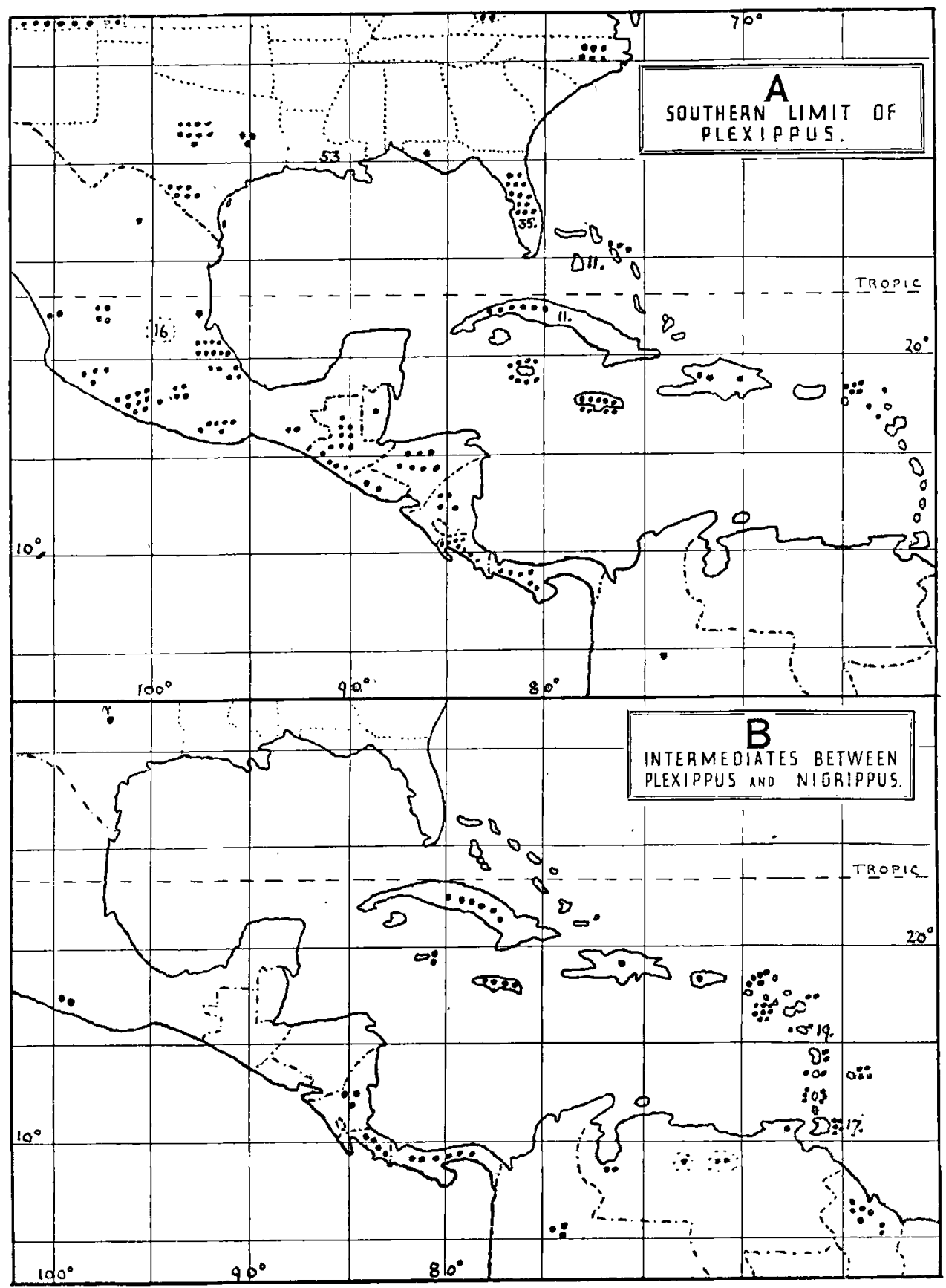

Fra. 18.-Map showing the distribution of the different geographical races of 
J. A. Downes on studies in the migration of Lepidoptera.

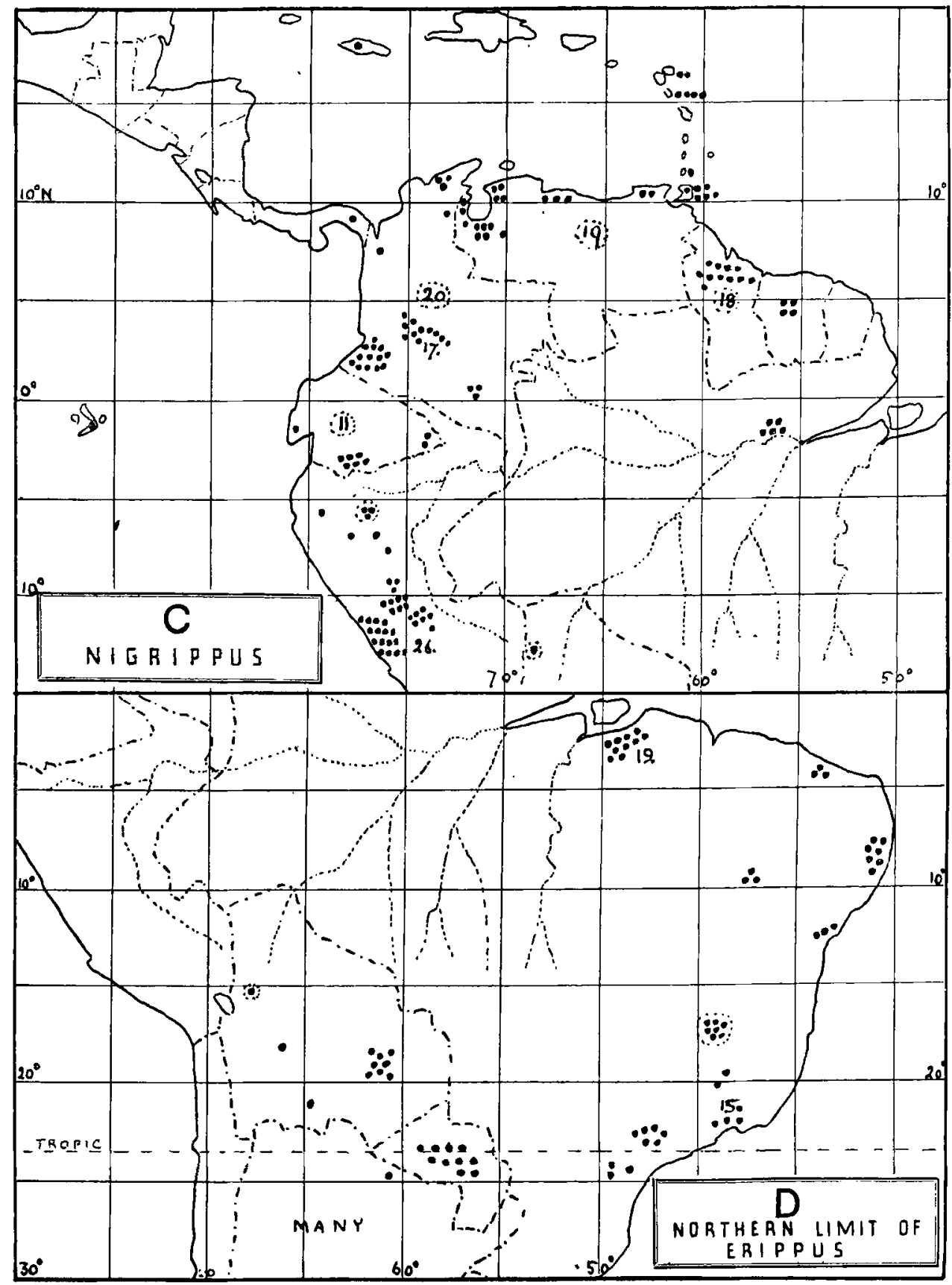

Danaus plexippus in North, Central and South America. 
The migrations and reproductive cycle of the Monarch butterfly in California.

\section{By J. A. Downes.}

In the Pacific Coast States Danaus plexippus L. performs migrations similar to those occurring in the East and Middle West, but the precise point of origin of the autumn migration, and the course of both the autumn and spring flights, seems to be largely unknown. However, several of the overwintering places, the termini of the autumn migration, are well known to West Coast entomologists, and are to a lesser extent recorded in the literature. The following notes deal with these overwintering places and with the behaviour and reproductive condition of the butterflies during the migrations and winter, for the seasons 1937-38 and 1938-39.

The overwintering sites. Williams $(1938 \mathrm{~b})$ records the following localities as winter resting-places for the western population: Stinson Beach, Marin Co.; Pacific Grove, Monterey Co.; between Pismo and Oceano, San Luis Obispo Co., and probably southwards to San Diego; Santa Monica, Los Angeles Co., Laguna Beach, Orange Co., and southwards: all in California. For all these localities it was known that the same place and sometimes even the same group of trees had been used by a group of the butterflies in several or even many winters. I have myself observed these overwintering groups at Stinson Beach; El Cerrito, Contra Costa Co.; Pacific Grove; at seven localities on the coast from about 20 to 40 miles south of Pacific Grove; Pismo; Santa Barbara; Ventura; and three places in the immediate neighbourhood of San Diego. There are also reports, which I was not able to check personally, from the Berkeley campus of the University of California; the shore of Napa Creek; Tomales Bay, Marin Co.; and at a site 15 miles inland in Contra Costa Co. Thus all the known localities are in California, rather widely spread out along the coast of about 600 miles, extending from Stinson Beach (or possibly Tomales Bay) in the north to San Diego in the south; but there are undoubtedly others farther south along the coast of Baja California. Moreover, all localities are very close to the coast, or the shores of San Francisco Bay; nearly always within half a mile of the water, but as much as fifteen miles away at the possible inland Contra Costa Co. record.

In all cases the actual place chosen is a fairly large and dense group of trees, usually but not always in an exposed position such as on top of a cliff. The tree chosen varies, and is probably not an important factor; at Pacific Grove it is Monterey Pine, at El Cerrito Monterey Cypress and Eucalyptus, and at most other places Eucalyptus alone.' They are all evergreens, as are practically all the trees in the coastal regions. The butterflies settle on the leaves and twigs, fairly high up (always above $20 \mathrm{ft}$.), and, at least when the group is large, are exceedingly gregarious (Plate 2). Thus at Pacific Grove in the winter of 1938-39, of a group of the order of 10,000 individuals, at least nine-tenths were clustered on only five small branches where they hung in great masses almost obscuring the leaves. This spectacular massing has been observed at Pacific Grove, Pismo, Santa Barbara, Ventura, Santa Monica region, and San Diego, but in most places the groups are smaller (a hundred or so, and more usually only about a dozen) and the clustering, if it occurs, has not been noticed. In most places where large groups have been observed, and also at Stinson Beach and El Cerrito, it is a matter of common knowledge that the butterflies return every winter to the same group of trees, and sometimes even to the same branches; at Pacific Grove there are some permanent signposts to "The Butterfly Trees," which are one of the sights of the town. The 
problem therefore presented itself to some entomologists: "How are the autumn butterflies, which are separated by from one to several generations from the group resident in the preceding winter, able to find their way year after year to these few small places from points perhaps many hundreds of miles away?" In reality, however, the situation is much simpler, as the following observations show. For twenty miles along the coast a little south of Pacific Grove (Nov. 1938) and for ten miles in the neighbourhood of San Diego (Jan. 1939) every suitable group of trees was examined; only fourteen possible sites were found, at ten of which at least a few Monarch butterflies were seen. There is no doubt that this is typical of the situation along the whole coast from San Francisco to below the Mexican line. The fact that they occur at almost every suitable locality had previously been overlooked as in most cases the number of butterflies is very small. It would seem therefore that the butterflies reach any point on this long coast line and then collect at, or discover, practically all the groups of trees, remaining in numbers proportional to the suitability of the sites found. The migration is therefore merely to the coast, and not to particular small places.

TABLE 16.

Presence of spermatophores (indicating pairing having taken place) in overwintering females of $D$. plexippus in California.

\begin{tabular}{|c|c|c|c|c|c|c|c|c|}
\hline \multirow{2}{*}{ Date } & \multirow{2}{*}{ Place } & \multirow{2}{*}{$\begin{array}{c}\text { No. } \\
\text { examined }\end{array}$} & \multicolumn{6}{|c|}{$\begin{array}{l}\text { No. with the following nos. of } \\
\text { spermatophores }\end{array}$} \\
\hline & & & 0 & 1 & 2 & 3 & 4 & $\mathbf{5}$ \\
\hline $\begin{array}{l}24 \text { Oct., } 1938 \\
1 \text { Jan., } 1939 \\
7 \text { Feb., } 1939 \\
17 \text { Feb., } 1938 \\
27 \text { Feb., } 1939 \\
7 \text { April, } 1939 \\
7 \text { April, } 1939 \\
9 \text { April, } 1939\end{array}$ & $\begin{array}{l}\text { Pacific Grove } \\
\text { San Diego } \\
\text { Pacific Grove } \\
\text { El Cerrito } \\
\text { Pacific Grove } \\
\text { San Francisco } \\
\text { Stinson Beach } \\
\text { Pacific Grove }\end{array}$ & $\begin{array}{r}12 \\
7 \\
5 \\
12 \\
2 \\
2 \\
1 \\
1 \\
3\end{array}$ & $\begin{array}{l}8 \\
3 \\
1 \\
5 \\
- \\
- \\
- \\
-\end{array}$ & $\begin{array}{l}4 \\
3 \\
4 \\
6 \\
2 \\
- \\
-\end{array}$ & $\frac{\frac{1}{1}}{\frac{1}{1}}$ & $\begin{array}{l}- \\
= \\
= \\
=\end{array}$ & $\begin{array}{l}= \\
= \\
= \\
\overline{1}\end{array}$ & $\begin{array}{l}\text { 二 } \\
\text { Z } \\
\text { ב } \\
\frac{1}{1}\end{array}$ \\
\hline
\end{tabular}

The resting sites are not chosen for their proximity to the larval food-plant, since, at least in all localities north of Pismo, Asclepias is absent or very rare for many miles around the trees chosen, as recorded by Williams for Pacific Grove. Also, not all sites are sufficiently far south to avoid a considerable mortality through unfavourable weather conditions. At El Cerrito, on 17th Feb. 1938, a cold and rainy day, many of the butterflies were numb and helpless, and when blown off the trees were either drowned in the puddles beneath or carried out into the Bay. Others were found dead on the ground, apparently killed by the cold. This sort of thing probably happens quite frequently as most of the chosen groups of trees are in such exposed windswept places.

The overwintering butterfies. On normal days, however, a small proportion of each group is active, flying around the trees, feeding at flowers, and occasionally mating. It is therefore slightly inaccurate to speak of the butterflies as hibernating. In the group of about 10,000 at Pacific Grove in the winter of 1938-39, feeding and mating were observed on all the visits made : Oct. 24 (10 pairs mating); Feb. 4 (7 pairs); Feb. 27 (5 pairs); Mar. 19 (5 pairs) and April 9 (2 pairs). A little more information can be extracted from Table 16 based on

TRANS. R. ENT. SOC. LOND. 92. PART 1. (JULY 1942.) 
an examination of the bursa for the presence of spermatophores. This shows that mating had started by 24th Oct., soon after the arrival of the autumn migrants; that most butterflies had mated once by the end of the winter; and that in early April, just before the start of the spring migration, individuals that had already mated did so again fairly frequently.

In March and April, a greater proportion of each group becomes active, flying around and feeding at almost any available flower, but a nucleus of the cluster remains until at least mid-April (Pacific Grove). During this time, occasional butterflies were observed up to six miles away from the Pacific Grove colony on sunny days, and a similar wandering occurs around other centres, but it is not known if such butterflies ever return to the parent cluster, which is still existing. It seems likely that each individual goes through this active period before starting on the migration proper.

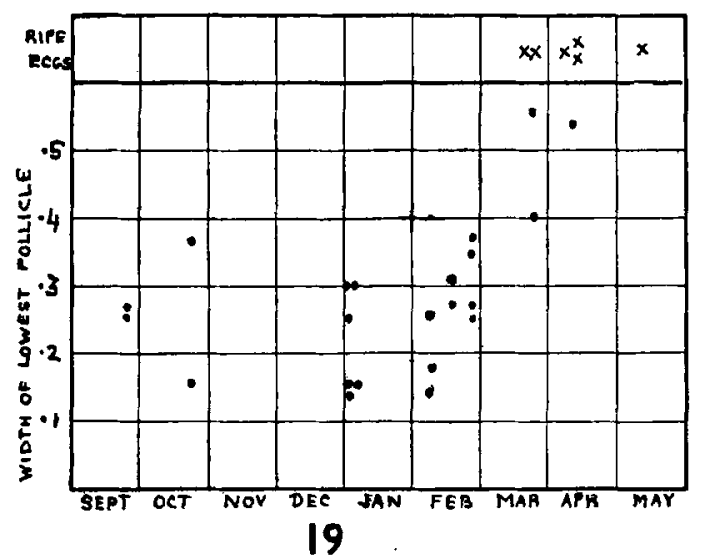

FIG. 19.-Width of the lowest follicle in the ovaries of overwintering $D$. plexippus in California arranged according to date of dissection.

The reproductive cycle during the winter is as follows.

I. The male. The spermatozoa are discharged from the testis into the vesicula seminalis and other parts of the genital ducts in elongate bundles each containing many spermatozoa. Spermatozoa in this condition are judged to be ripe.

A male bred from a Berkeley larva on 21st Sept. 1938, and dissected two days later, was found to have ripe sperm in the testis but none in the vesicula seminalis or in the lower part of the duct (the "paired gland " of Norris, 1932, Proc. zool. Soc. Lond. 1932 : 595). Two males taken at Pacific Grove on 25th Sept. 1938, before the arrival of the main mass of the migrants, had ripe sperm in testis, vesicula and paired gland; while the same was true of two other males from there examined on 24th Oct. 1938, about two weeks after the arrival of the migrants. A male was also examined on 5th Feb. 1939 (Pacific Grove), another on 31st March 1939 (Berkeley), and two on 8th May 1938 (Pacific Grove): in the two former ripe sperm were present in testis, vesicula, and paired gland; in the latter the gland was not examined but sperm were found in both testis and vesicula. It appears therefore that ripe sperm occur in both testis and ducts very soon after emergence and before arrival of the migrants at Pacific Grove; and probably at all times during the winter until the spring migration. 
II. The female. The overwintering female emerges from the pupa in September with all its egg-follicles quite small and unripe. They develop slowly during the winter months and the first females with ripe eggs (i.e., eggs with the shell formed) were observed on 26th March 1938 at Pacific Grove. Table 17 shows something of the course of development of the ovaries as judged by the width of the lowest (ripest) egg-follicle. The female has eight ovarioles, all in very nearly the same stage of development, and the figures given are the averages of the eight measurements taken from each individual. These results are shown diagrammatically in fig. 19.

\section{TABLE 17.}

Development of ovaries as indicated by the width of the lowest egg-follicle in overwintering D. plexippus in California.

\begin{tabular}{|c|c|c|}
\hline Date & Place & $\begin{array}{l}\text { Width of } \\
\text { lowest follicle }\end{array}$ \\
\hline $\begin{array}{l}24 \text { Sept., } 1938 \\
24 \text { Oct., } 1938 \\
\text { 1 Jan., } 1939 \\
\text { ", } \\
\text { ", } \\
7 \text { Feb., } 1939 \\
17 \text { Feb., } 1939 \\
27 \text { Feb̈., } 1939 \\
\text {," } \\
\text { ", } \\
26 \text { Mar., } 1938 \\
\text {," } \\
\text { ", } \\
7 \text { April, } 1939 \\
9 \text { April, } 1939 \\
\text { ", } \\
8 \text { May, } 1938\end{array}$ & $\begin{array}{l}\text { Berkeley (just emerged) } \\
\text { Pacific Grove ", } \\
\text { San Diego } \\
\text { ", } \\
\text { ", } \\
\text { Pacific Grove } \\
\text { El Cerrito } \\
\text { Pacific Grove } \\
\text {," } \\
\text { ", } \\
\text { ", } \\
\text {," } \\
\text { ", Beach } \\
\text { Stinson Grove } \\
\text { Pacific Grove ," } \\
\text {," }\end{array}$ & $\begin{array}{l}0 \cdot 25 \mathrm{~mm} . \\
0 \cdot 26 \\
0 \cdot 16 \\
0 \cdot 37 \\
0 \cdot 14 \\
0 \cdot 15 \\
0.15 \\
0 \cdot 25 \\
0 \cdot 30 \\
0 \cdot 30 \\
0 \cdot 19 \\
0 \cdot 25 \\
0 \cdot 28 \\
0.31 \\
0 \cdot 25 \\
0.28 \\
0.35 \\
0.37 \\
0.41 \\
0.55 \\
1 \text { ripe egg } \\
6 \text { ripe eggs } \\
7 \text { ripe eggs } \\
0.53 \text { mm. } \\
1 \text { ripe egg } \\
5 \text { ripe eggs } \\
1 \text { ripe egg }\end{array}$ \\
\hline
\end{tabular}

It will be seen that there is only a very slight increase in egg-size until the end of February, followed by a stage of rapid growth in early March, for which period there are unfortunately no records. Growth during the winter months is, however, more active than would appear from the table, as it is being offset by an opposite process of egg degeneration, which continually destroys the largest follicles during this period. In some cases this degeneration at the lower end of the ovariole goes on faster than the upper eggs are growing : this accounts for those winter records in which the lowest egg is smaller than it is in newly emerged butterflies. The eggs are ripe and ready for laying from late March and early April onwards. No case was found of an overwintering individual that had laid eggs before the winter; always the plug separating the ovariole 
proper from the oviduct was intact until the spring. It will also be seen that most females have already mated when their eggs were quite unripe; it is not known whether a second mating, in spring, is necessary, but as shown above such a mating commonly takes place.

The migrations. The autumn migration to the Californian coast takes place usually in early October, but possibly is not complete until a month or more later. I have no exact records of the time of arrival of the butterflies at their overwintering sites, and the comparative scarcity of records of large flights in the West makes one suspect it is not always carried out by compact masses of butterflies as it is in the East. The males have at this time ripe sperm in both testes and ducts, while the females have the egg-follicles quite immature, hardly larger than they were in emergence, and degeneration is already setting in. Mating has either just started or will do so very soon.

As there are no discaverable records of the butterfly in inland California during the winter months the migration would seem to be complete, except for any females in egg-laying condition, which, as they never arrive at the coast, presumably die inland before the winter.

The spring migration is certainly spread over a considerable period, and is carried out by butterflies moving more or less alone. The time of its start can be judged only from indirect observations. A female with 4 ripe eggs in each ovariole was taken at Alum Rock Park, Santa Clara Co., about 50 miles from the coast on 9th April 1938, and a dozen others were seen at the same place and time. Four males were taken in Owens Valley, some 200 miles inland, on 17th April 1938. On 14th May 1939 in the Yosemite Valley a well-grown larva was found; this pupated on 22nd May and emerged 9th June. The egg from which it developed had been laid probably about 20th April. Five newly-emerged adults, however, were found on 4th June at Mariposa; these must have come from eggs laid about 12th April. On 12th June adults and just-hatched second generation larvae were found east of Reno, Nevada, indicating that the migrants had penetrated about 250 miles inland by mid-April. All these data point to the fact that the spring migration is in progress in early April, and that the whole of California is repopulated by the middle of the month. The later discussion on the change in sex-ratio in the Pacific Grove colony will show that the first migrants probably leave in March. Many butterflies, however, are still at Pacific Grove in mid-April, and as will be seen some are still there as late as 8th May. It is indeed possible that the spring migration is never quite complete, as butterflies can be seen around Berkeley, 1-2 miles from the El Cerrito wintering site, at all times of the summer; these may, however, be individuals that have wintered farther south and performed a normal migration.

It seems therefore that the first butterflies migrate very soon after the eggs have begun to ripen, and that the others do so during the month (April) in which ripe eggs are to be found in those females that still remain at the overwintering places. The males migrate with ripe sperm in both testes and ducts. The reproductive condition of the males is thus seen to be the same, while that of the females is very different, on the two journeys.

This account of the migrations was written from data obtained at Pacific Grove and northwards, and it is likely that the migration begins somewhat earlier farther south. Also, although in general the reproductive condition of the butterflies is the same in both southern and northern localities throughout the winter, as shown by the undeveloped condition of the San Diego females, exceptionally a southern female is found to be mature during the winter months. Thus two specimens were bred on 4th April and 7th April 1931 from eggs laid 
in the wild at Fullerton, Orange Co., in December 1930 (Mr, J. W. Johnson), and females taken after their arrival at overwintering places near San Diego in November 1936 laid eggs after two weeks in captivity (Capt. Medlar). The migrating instincts of such unusual individuals are not known.

The sex-ratio of the overwintering butterfies. In most localities males and females occur in more or less equal numbers during the winter months. Fifteen males and 14 females were observed at San Diego, 1st Jan. 1939, and 10 males and 21 females at El Cerrito, 17th Feb. 1938. At the Pacific Grove colony, however, males consistently outnumbered females in both the 1937-38 and the 1938-39 season, and from the beginning of March onwards the proportion of females decreased still further until very few could be found, while the males remained in thousands until at least 8th May. The figures for those actually caught and sexed are as follows (the two seasons' records being combined).

\begin{tabular}{|l|c|c|c|}
\hline \multicolumn{1}{|c|}{ Date } & Males & Females & Ratio m. : f. \\
\hline 24 Oct., 1938 & 54 & 26 & $2 \cdot 1: 1$ \\
4 Feb., 1939 & 51 & 29 & $1 \cdot 8: 1$ \\
27 Feb., 1939 & 41 & 14 & $2 \cdot 9: 1$ \\
19 Mar., 1939 & 12 & 2 & $6 \cdot 0: 1$ \\
26 Mar., 1938 & 100 & 8 & $12 \cdot 5: 1$ \\
9 Apr., 1939 & 35 & 4 & $8 \cdot 8: 1$ \\
8 May, 1938 & 27 & 1 & $27 \cdot 0: 1$ \\
\hline
\end{tabular}

Actually, the proportions on 26th March and 8th May 1938 were much more extreme than they appear from the table. Almost all the females seen on those days were mating, and it was apparent that the many single specimens were nearly always males. In all probability the sex-ratio on 26th March was of the order of $100: 1$ and on 8th May $1000: 1$. It is not known whether these males eventually migrated or whether they died at Pacific Grove. It is clear, however, that the spring migration of most groups is carried out by males and females together, and as noted above, males were found in Owens Valley, 17th April 1938. This unusual phenomenon at Pacific Grove is quite without an explanation.

Note by C. B. Williams :-As additional information on this point I may add that in the spring of 1932 at St. Paul, Minnesota, the first Monarch of the year that I captured on 30th May was a male, and of three others captured within the next week one was also a male. There is therefore positive evidence that both sexes migrate north simultaneously in the spring.

D. plexippus, migrations in North and Central America and the West Indies.

By C. B. Wilniams.

Since my last summary of the migrations of this butterfly (Williams 1938b) a number of additional records have come in which are summarised below.

United States of America.

Alabama. In September 1936 Monarchs were observed in rather large numbers at Auburn by H. S. Swingle. 
In the autumn of 1937 they were observed at Montgomery, moving to the S.E. with many $C$. eubule and D. vanillae, by P. H. Smyth.

Arkansas. Mr. A. M. Merrill of Rogers, Ark., writes: "Anosia plexippus passes through here in October and is usually scudding before a cold north wind, and very high in the clouds. Usually before the great hosts arrive there will be thousands flying slowly near the ground, and a little south by south-east. These take their time and often rest at night on tree limbs in such weights as to bend the limb almost to the ground. When a ' northerner' 2 strikes they rise and go with it night and day till they reach warmer weather. Sometimes they are accompanied by Pyrrhanaea andria in their high flights. . . . One night in October $1921 \mathrm{I}$ went out into the yard to view the moon. I had a three-inch telescope and the wind blew hard from the north. In looking at the moon we saw thousands of Anosia and Pyrrhanaeas passing over the field of the telescope. They numbered probably millions but could only be seen as they neared the light of the moon."

California. The most northerly point at which $I$ have records of hibernation of Monarchs is on the coast just north of San Francisco at Stinson Beach and Bolinas.

At Stinson Beach Mrs. Atherton-Coleman writes that in 1937 they arrived in late summer and remained until March 1938, hanging thick about the Eucalyptus and Escallonias. During March they broke up and by the 4th April only a few bedraggled specimens with broken wings were seen here and there. She writes: "I cannot help noticing their fondness for the coast; inland they seem scarce."

In 1938 they began to arrive about the end of October and swarmed all through November.

At the Bolinas, according to Mr. A. R. Duperu, they appeared about 1st September 1937. In November 1937, Mr. Duperu sent 50 specimens which included 29 males and 21 females. The butterflies left during March and only a few stragglers were present on the 1st April. In 1938-39 they arrived during August and left about 31st March.

At Pacific Grove, Monterey, many observations have already been recorded. In the autumn of 1937, according to Mr. Alan Forbes, the butterflies arrived about the 10th-20th October. He says, "I was not able to observe any massed arrival, the butterflies increased day by day, noticeably." On the other hand, he quotes a record from the previous year (1936) when they were seen by an observer to arrive in a swarm about five o'clock in the evening from the direction of Santa Cruz (north).

During October and November five or six mating pairs were seen, and again during March 1938 when Mr. Forbes sent me four pairs captured when mating. In the spring of 1938 they began to leave about the 25th March. By the 20th April there were still plenty about but they were more and more scattered. On 18th October $1937 \mathrm{Mr}$. Forbes sent me 21 specimens which included only 3 females, and on 8th March 1938 a dozen more (apart from the four pairs) which included only 3 females (see p. 165).

In the autumn of 1938 they were observed by Miss M. Bondfield. "They began to arrive on Saturday, 8th October, just a few. On Sunday 9th the swarm was beginning to settle on the trees and they were already an astonishing sight. On 10th October the whole swarm had practically arrived, as only an occasional one could still be seen in the air."

${ }^{2} \mathrm{~A}$ cold wind from the north. 
A full account of Mr. J. A. Downes' observations at this locality will be found on p. 160.

Two new records of directional flights are also available for California. In August 1912, at Marble Mts., Siskyou County, California (according to a record from Mr. Alan Forbes), an observer at the summit of the pass, much lower than the surrounding mountains, suddenly came upon an amazing line of butterflies. They were coming up the slope as far as could be seen, then crossing the summit and immediately descending in line far beyond vision. The flight was watched for half an hour and was still passing "in countless millions." Nearly all were from 10 to 20 feet above the ground and they never alighted.

In mid or late September in 1917 or 1918, near Los Angeles, Mr. P. M. Gillmer saw a big scattered flight one evening about sundown. One individual every 20-30 feet in all directions and up to at least 100 feet high. The general direction of the movement was to the south. It was said to be a regular occurrence in the district.

Connecticut, Britton (1934, Rept. Conn. State Ent. : 251) says that in 1934 the Monarch was unusually common and thousands were seen clustered on the trees at Sacham Head, Guildford, on 20th August. They settled at 7-7.30 p.m. and resumed flight the next morning.

District of Columbia. According to a letter from Dr. E. Murray-Aaron, a flight was observed in Washington, D.C., by Dr. Ashmead at the end of September 1893.

Florida. Notes on the occurrence of the Monarch in Florida as observed by Mr. and Mrs. K. Hodges will be found on p. 147.

Mrs. W, G, Colvin, writing from Davenport, Florida, says that in the fall of 1937 the first was seen on 20 th November, another about a week later, and then one or two others. Then came a frost which killed the Poinsettias and until the end of March 1938 not one was seen. "Never seen so few butterflies for 11 years."

In the fall of 1938 they began to arrive early in November and were seen in moderate numbers up to the 3rd February. Mrs. Colvin writes that no Monarchs are seen except during the winter months.

At Englewood (on the west coast of Florida) Mr. W. F. Smith reports about 47 seen in December 1937, but none from lst January to 4th April 1938, including observations made on a trip to the extreme south of Florida at the end of January. In the fall of 1938,14 were seen between 22 nd arid 30th November, 87 in December and 36 in the first three weeks in January. In December 1938 Mr. Smith marked several Monarchs by clipping their wings. The longest period during which any one was observed was 11 days.

Georgia. Mr. T. L. Bissell writes (in 1937), "About five years ago (i.e., about 1932) at Experiment, Georgia, I saw about 200-300 Monarchs moving round a water tank and adjacent trees one day in the fall. They were about 50 feet in the air:"

In the fall of $1933 \mathrm{~L}$. Harris observed a noticeable flight towards the S.E. at Atalanta, Georgia. The butterflies were flying high in the air, often several visible at once from the ninth floor of an office building.

At the end of September and beginning of October 1934 and 1935, congregations were observed at Marietta, according to Mr. W. A. Ruffin.

Illinois. Shannon (1935) on map p. 157 records flights to the south at Winchester, Illinois, for 25 years.

In the fall of 1934, Dr. E. Murray-Aaron observed desultory stragglers in 
small flights of a few dozen to some hundreds over the Skokee Marshes, north of Chicago.

On 5th September 1934, according to Mr. P. Viosca, thousands of large butterflies, believed to be Monarchs, appeared high in the air round the lights of the Chicago Exhibition.

Indiana. On the 6th September 1934 during a cold north-east wind, hundreds of Monarchs were found clustered in trees on the Indiana Dunes State Park on the south shores of Lake Michigan, according to P. Viosca.

On 20th September 1937, at New Haven, Ind., Mr. C. Fredrickson observed a migration of Monarchs to the south about one mile from the town. About 500-1000 individuals were flying about 6 feet from the ground with a N.W. wind. It was growing dusk and temperature about $75^{\circ} \mathrm{F}$.

Iowa. Mr. F. Braillian writes that in the first weeks of May 1884, in Iowa he saw large numbers of Monarchs flying to the north. This is one of the few records of the mass flight to the north in the spring.

In late September 1916, according to Shannon (1935, map p. 157), there was a flight to the south at Alexandria, which appears to be in either S.E. Iowa or N.E. Missouri.

Kansas. Prof. H. R. Bryson writes (Dec. 1937), "We notice migrations of the Monarch at Manhattan, Kansas, in October. Usually they go almost straight south. They may arrive at $10 \mathrm{a.m}$. and all be gone by 1.30 or $2.0 \mathrm{p} . \mathrm{m}$. I recall last fall (1936) counting 23 at one time on a Morning Glory vine at noon, but all had gone by 2 p.m."

Smith and Kelley (1938) report that the first individuals of 1937 were seen in Eastern Kansas on 15th June and in Riley Co. on 21st June.

Kentucky. Mr. W. A. Price writes (Nov. 1937), "Nearly every year from 22nd to 30th September Prof. Garman and Miss Didlake have noted these insects from the windows of the laboratory at Lexington, $\mathrm{Ky}$., not crowded but scattered individuals always flying southwards."

Mr. C. O. Eddy writes that he has observed similar flights at Lexington for a number of years. Huge migrations take place which extend at least for several miles on each side of the town. The mass movements are usually over in two or three days but may last about a week. Once he saw one just as a storm was coming up. The butterflies massed on the sheltered side of a tree but did not settle until the rain began. They then flew towards refuge places under the limbs and lighted on leaves, stems and bark.

On 30th September 1933, at Camp Nelson, about 20 miles south of Lexington, hundreds were observed settled on the limbs of a Sugar Maple tree by Prof. H. Garman and Miss M. Didlake.

On 20th October 1934 great numbers were observed going to the south at Lexington by Mr. W. A. Price.

Louisiana. Mr. P. Viosca writes: "Although Monarchs are absent in the deep south during the summer months, they arrive along the Gulf coast in numbers during October and November, apparently with northerly winds. Danaus berenice, although only a small percentage of the total, takes part in the migration. If the weather moderates after they reach the Gulf coast they linger awhile and even lay eggs. On one occasion I observed a full crop of caterpillars on a species of Milkweed near New Orleans. After this migration we do not see any more throughout the winter."

In 1934, on 20th and 27 th October, Mr. Viosca saw small numbers flying to the south over Lake Pontcharitrain, north-east of New Orleans, and on the 26th in New Orleans itself. 
In November 1937 Mr. Viosca captured 57 specimens in St. Tammany Parish and sent them to Dr. A. H. Clark at Washington, who reported that 3 males and 1 female were of the nigrippus form.

In 1930 the first Monarch of the spring was seen on 26th Mareh and the first of the autumn on 20th September. After this none was seen until 8th October and then occasional individuals throughout October; all these were in the New Orleans area.

On the other hand, Dr. P. B. Hussey, D. C. Elliott and H. A. Jaynes write that they have never observed mass movements in Louisiana.

Maryland. At the end of September 1893 a swarm was observed at Baltimore by Dr. Uhler, according to information received from Dr. E. MurrayAaron.

In 1937 , according to E. N. Cory (1937), they began to assemble at Piney Point, St. Mary's Co., on 7 th October, and by the following day over 500 had assembled in the neighbourhood. He sprayed them with a green dye, but has not recorded any recaptures.

Massachusetts. Mr. W. T. M. Forbes reports that in 1899, 1900 and 1901 at Worcester, Mass., the Monarchs gathered each fall in a beech tree at the foot of his grounds, hung about for a few days and then disappeared all at once. There were only about a thousand and invariably on the one tree. He suggests that they were gathering here from the surrounding square mile or so preparatory to moving south.

According to Mr. K. Merrill, Monarchs appeared in great numbers on Great Misery Island, off Manchester, Mass., at the end of August in 1934 and 1936. They did not appear in numbers on the mainland until about two weeks later.

Mississippi. Mr. C. Lyle writes that in 1923 at the end of October or early November he observed large concentrations of Monarchs massing on lowhanging, moss-draped branches of live-oak. This was on the Gulf coast of Mississippi about 6 or 7 miles west of the city of Bay St. Louis and only a few yards from the shore. They showed no signs of fear, and large numbers could be captured by hand.

At the same time large numbers were observed flying from east to west at Bay St. Louis, while equally large numbers of $C$. eubule were flying towards the east.

New Jersey. Dr. E. Murray-Aaron records that on 25 th and 26 th September 1893 at Frenchtown, N.J., on the Delaware River about 30 miles north of Trenton, he saw a migration of Monarchs heading to the south for two days, following the course of the river, and flying against a steady head wind.

New Mexico. Mr. P. R. Gleason, writing September 1939, says that in June 1939 he saw no Monarchs, in July only one and in August about three.

New York State. In September 1920 Mr. V. D. Carr observed large numbers of Monarchs near Rochester settling on a dead oak about 35-40 feet high. All small branches and many of the larger were covered with butterflies. Some were coming in from the north from over the lake.

In September $1935 \mathrm{Mr}$. Carr observed a flight from the north at Port Bay, about 50 miles east of Rochester. These marle two sharp turns over the water (see discussion on p. 226). Many thousands passed in a narrow belt only 10-12 feet wide.

One day in mid-September 1935, according to Mrs. L. B. Unkefer at Endicott, N.Y., the air was filled with butterflies going to the south-west. Not a compact swarm but always many visible : mostly 10-20 feet up, and flying nearly against the wind. 
Mr. Mahuken reports that in the fall of the same year they were moving south in New York City, and again in the first half of September 1939; they were going south-west in most cases against a wind of about 10 m.p.h. None was noticed there in 1936, 1937 or 1939.

North Carolina. Mr. C. S. Brimley writes that some time before 1919 in the springtime in North Carolina some boys brought him a number of Monarchs with the statement that there were quantities more in a clover field then in bloom. It was probably in April.

Mr. F. Sherman writes that in the autumn of 1920 he saw a definite flight at Raleigh, N.C.; each minute $20-30$ would cross a front of 100 yards, the great majority going from north to south.

Mr. R. Dayton writes that at the beginning of October 1935 at Carolina Beach, 15 miles south of Wilmington, N.C., he saw a slight movement of Monarchs towards the south along with $P$. eubule. He adds that some stayed so late that they were paralysed with the cold and could be picked up by hand.

Pennsylvania. At the end of September 1893 for 3 or 4 days at Fairmount Park, Philadelphia, Dr. H. Skinner observed numbers of Monarchs congregating (according to E. Murray-Aaron).

South Carolina. Mr. F. Sherman writes that for 37 years he has worked chiefly in the two adjoining states of N. and S. Carolina. The Monarch becomes more abundant and conspicuous in the fall than at any other time, and the drift of flight seems to be southerly. The adults appear again in spring in fewer numbers and most appear worn, faded and often tattered. 'The drift northward in the spring does not seem so well defined as the southward drift in the autumn.

Mr. O. L. Cartwright reports that on 4th October 1934, between Walhalla and Clemson, S.C., Monarchs were seen about 10-25 per mile of road, all flying slowly to the south about 3-6 feet above the ground. Ninety-five were counted in 5 miles.

Mr. J. A. Berly writes that he has never seen any large migration in South Carolina but that each fall they appear to be travelling to the south.

Tennessee. Dr. E. Murray-Aaron records that in the autumn of both 1874 and ?1879 he saw flights of Monarchs in the Smoky Mountains between North Carolina and Tennessee. They were flying towards the south-east, passing through the gap of the Little Tennessee River.

Many years later Mr. G. M. Bentley observed a great congregation in the same area. He writes: "About 1929, in the Smoky Mountains, after a rain storm, trees were seen weighed down with butterflies, so that the lower limbs bent down 4-5 feet to touch the ground. About 10 a.m. the next day the butterflies began to detach themselves, flying round a little till myriads were flying in a hesitating flight to south and west."

Mr. Bentley notes that regular flights to the south occur in the State from mid-October to mid-November.

Mr. F. Braillian writes that on the Sequatchie Valley not far from Ohattanovga, Tenn., "there is an almost perpendicular rock wall, several hundred feet high, that practically locks the fall migration of the Monarch, and they sometimes gather together in a cove against the wall by thousands. Usually they finally find their way out and complete their migration, but I had a report two or three years ago from a man living there that severe freezing weather came before several thousand of these butterflies had found their way out and apparently killed them all."

At Bolivar observations were taken by Mr. C. McR. Plummer in 1938 and 1939. In October of 1938 he saw a few only travelling to south-east. In 
October 1939 the first was seen on 12th October and in the last week small numbers were going chiefly to the south.

Texas. E. Murray-Aaron writes that in 1884 , probably in early October, he saw numbers of Monarchs coming in over the sea at Corpus Christi.

In the same locality in $1938 \mathrm{Mr}$. B. Struck observed many Monarchs flying to the south from the 10th to 14 th November. He states that he has observed this southward movement in Texas for some years but never in very large numbers.

\section{Canada.}

According to $\mathrm{Mr}$. K. Bowman, a large congregation and migration to the south was noted by Mr. D. Gregson at Blackfalds, Alberta, in the " late nineties." Blackfalds is about 100 miles south of Edmonton.

\section{Mexico.}

Through the kindness of Dr. E. Murray-Aaron I am able to record that in 1890 the late Sir Rider Haggard observed a flight of thousands of Monarchs towards the south in Orizaba, Mexico. Dr. Aaron met him a few days later and confirmed the identification from some specimens that he had captured. This is the only record of flight at present known in Mexico.

\section{Porto Rico.}

F. Sein (1929) describes a flight of Monarchs flying towards the east in Porto Rico in "November" but gives no date or exact locality.

Mr. J. I. Otero reports to Mr. G. N. Wolcott that the flight was in 1928 and that he first noticed Monarchs in San Juan flying against the N.E. trade wind (i.e., from south-west to north-east) about a month after the hurricane of San Felipe, which was on the 13th Sept. 1928. The same day he noticed them also at Santurce and Rio Piedras. Most were at a considerable elevation and only a few came down to the ground. The flight lasted for about a week.

Mr. W. A. Hoffmann, referring to what he thinks is the same flight, says, however, that the butterflies seemed to be following the north coast and going in a westerly direction. Innumerable butterflies passed on one day and a few stragglers on the next.

\section{General Summary.}

In the map (fig. 20) and the diagram (fig. 21) will be found summarised all the available data on the dates, localities and direction of flights in North America.

From the map (which shows only the autumn flights) it will be seen that there is a general southerly movement over the whole of the eastern half of the U.S.A. and the great Mississippi Valley, and again movement along the Pacific coast. There is no evidence of mass migration through the mountainous belt of the Rockies.

Hibernation is recorded in Southern California and in Florida. The butterflies which pass south through Texas appear to carry on into Mexico, where I have only one single record of a southward migration (see above) and none of mass hibernation. In Louisiana there are at present no records of hibernation and some evidence that the butterflies are absent both in summer and winter: that is to say, are "birds of passage" only. 


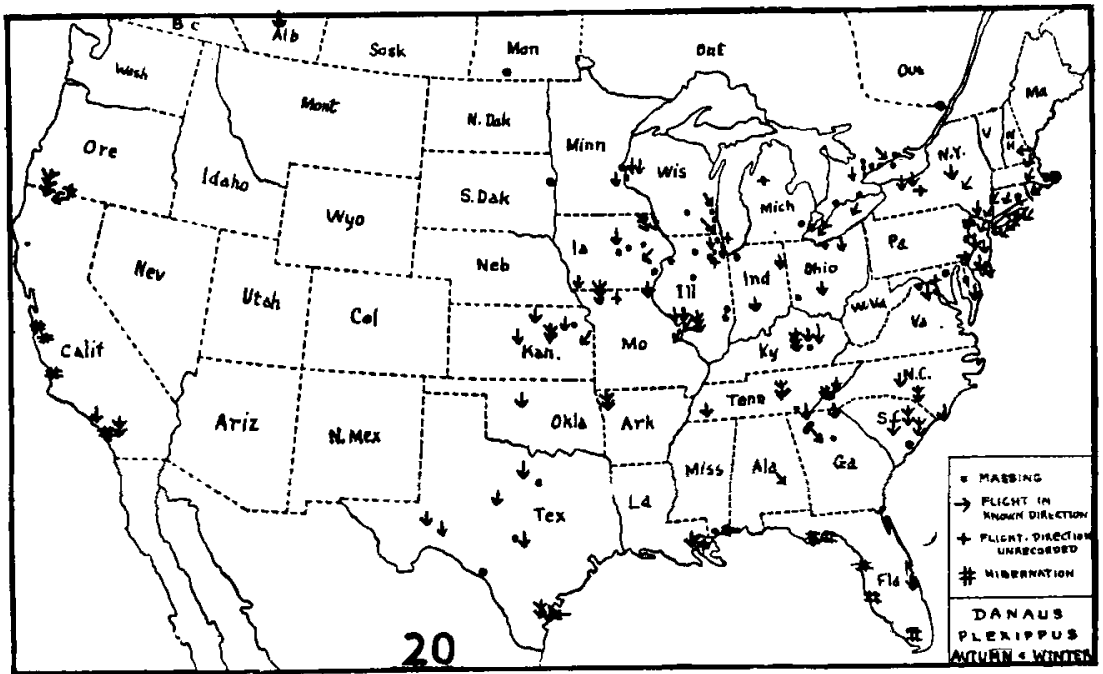

FIG. 20.-Recorded flights and hibernating localities of D. plexippus in North America.

From the geographical distribution of the races (p. 158) it seems possible that the North American migrant may cross the sea to the larger West Indian Islands, Cuba and Haiti and perhaps Jamaica, but it is unlikely that they go any farther across the Caribbean Sea.

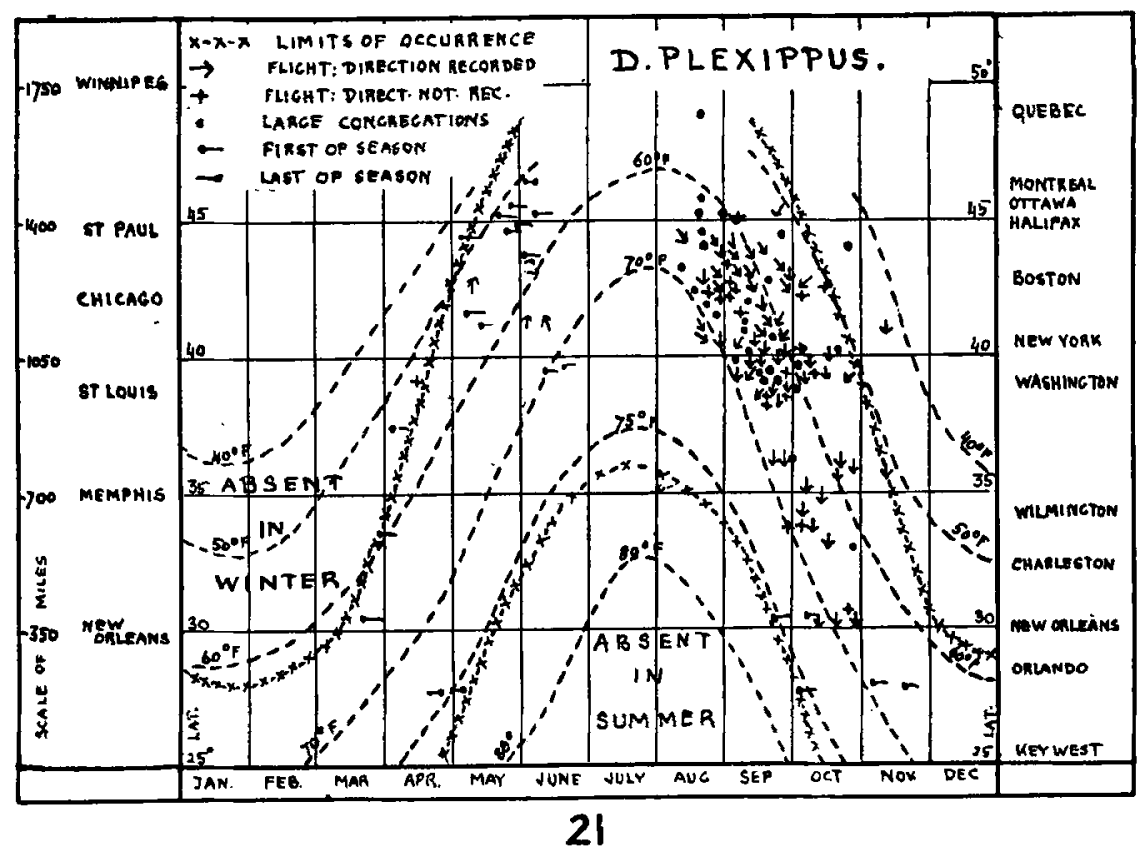

Fre. 21.-Diagram showing the movements of D. plexippus in eastern North America according to time of year and latitude. 
The diagram (fig. 21) is an attempt to show movements both in time and distance, north and south, in the same figure. Each recorded flight is put in in its corresponding date and latitude. Superimposed on the flight records are the isotherms for the mean temperature. It will be seen that the last butterflies appear to leave Florida in the spring when the mean temperature rises above $75^{\circ} \mathrm{F}$. and they begin to return at about the same temperature level. There is definite evidence in Florida of a period of summer absence. Possibly, however, they persist farther north, in Georgia, and in N. and S. Carolina, with mean temperature above $75^{\circ} \mathrm{F}$.

They do not seem to arrive in the north until the mean is over $50^{\circ} \mathrm{F}$. and leave again before the mean falls below the same level. They move both south and north more rapidly than the isotherms, with the result that they are moving steadily into cooler climates as they go north in the spring and into warmer ones as they go south in the autumn.

The most important points now to be settled are to find how far north the zone of complete absence extends in the summer; how far north winter hibernation can occur; and hence what is the extent of the area (which seems to exist in Louisiana) in which the butterflies appear only in spring and autumn. More observations in Mexico and Central America are specially needed.

\section{Migrations in S. America (D. erippus).}

In my previous summary only two records of flight were given; both seen by Hayward in the Argentine Republic in March and April and both towards the north. They were therefore moving towards the Equator in the autumn.

Dr. Malcolm Burr informs me that he saw a big flight of this butterfly at the mouth of the River Plate, near Buenos Aires, at the beginning of April 1891. From his notebook the following extracts are taken :-

" 2 April 1891-Today a swarm of big butterflies came off from the shore and I was all the time catching them. With others to help me I got 68 specimens.

" 3 April. Today we caught another.

" 4 April. Today we caught some more, making the total 72."

He had arrived in Buenos Aires on 21st March and left on 6th April but was unable to go ashore owing to quarantine. No note was made at the time of the exact direction of flight.

A. Wetmore (1926) states that he has observed migrational movements of $D$. erippus "that wintered in numbers in the Chaco and in the spring flew southward to spread over the pampas." The Chaco is in north Argentine and the adjoining portions of Bolivia and Paraguay. In a letter he adds : "I first observed $D$. erippus in July and August in the Chaco. The insect was very common here. . . . In October I saw them moving down into the open Pampas Country to the south and observed them occasionally throughout the summer. In February, in Uruguay, they were again in evidence. I did not see the great migratory flights in S. America that I have watched on occasion in U.S.A."

In addition to the above records of directional flight there are two records of the capture of the insect out at sea in the Atlantic. In the British Museum is a specimen labelled " 23 February 1931, at sea 60 miles off Rio Plata, Brazil " captured by W. W. Holmes on H.M.S. Eagle. On 20th February 1939, a female was captured on S.S. Alcantara when in Lat. $12^{\circ} 22^{\prime}$ N., Long. $27^{\circ} 01^{\prime}$ West while on a voyage from S. America to Europe. This is only about 200 miles south of the Cape Verde Islands and much nearer to Africa than to S. 
America. The specimen was sent to me by Mr. E. M. Barker. It is remarkable that a S. American erippus should be found so far from shore when the Monarchs caught in the Cape Verde, Canaries and Azores are all typical N. American forms.

\section{D. plexippus in Great Britain.}

In the past sixty-four years, 57 individuals of $D$. plexippus have been captured in England, Wales and Ireland and a further 94 reported as having been seen but not captured. No specimen has been reported from Scotland.*

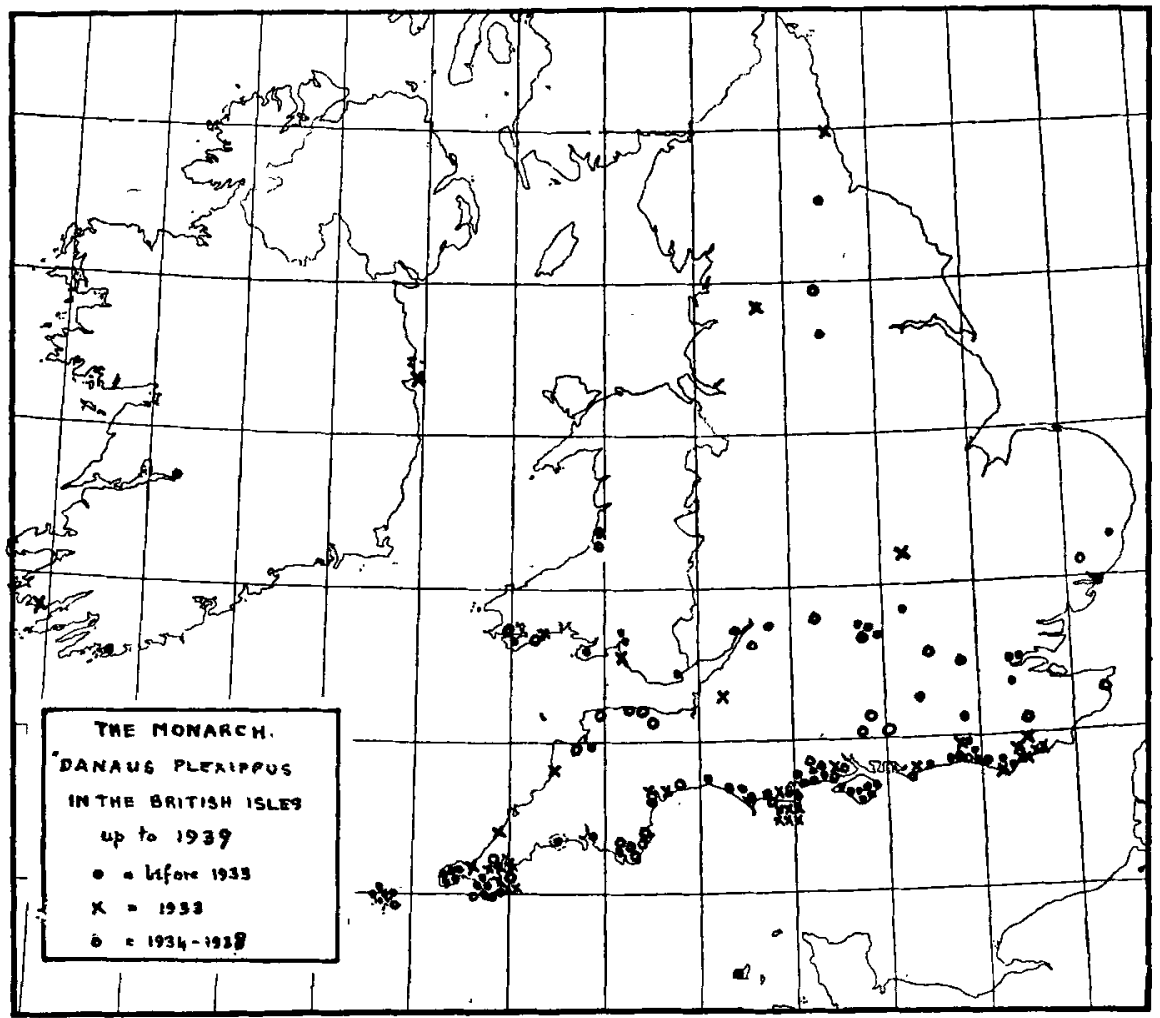

\section{2}

FiG. 22.-Map showing the position of records of D. plexippus in the British Isles.

Brief details of all those captured together with the first reference traced for each are given in Table 18. The localities of capture are all marked on the map (fig. 22).

It will be seen that the great majority are along the south coast of England, with a few along the south coast of Wales and Ireland and only a relatively small number inland. The farthest north capture is one in Co. Durham in Sept. 1933.*

The capture of Monarchs each year in Britain is shown diagrammatically

* Since this was written one has been captured in the Shetland Islands, see Table 18 no. 151 . 